\title{
SOME THOUGHTS ON "DEOSSIFYING" THE RULEMAKING PROCESS
}

\author{
Thomas O. MCGARITY*
}

As the "rulemaking era" dawned in the early 1970s," the courts, commentators, and most federal agencies agreed that informal rulemaking under section 553 of the Administrative Procedure Act (APA) offered an ideal vehicle for making regulatory policy. Professor Kenneth Culp Davis captured the prevailing sentiment only somewhat hyperbolically when he called informal rulemaking "one of the greatest imventions of modern government." 2 Twenty years later, the bloom is off the rose. ${ }^{3}$ Although informal rulemaking is still an exceedingly effective tool for eliciting public participation in administrative policymaking, it has not evolved into the flexible and efficient process that its early supporters originally envisioned. Durmg the last fifteen years the rulemaking process has become mcreasingly rigid and burdensome. An assortinent of analytical requirements have been imposed on the simple rulemaking model, and evolving judicial doctrimes have obliged agencies to take greater pams to ensure that the technical bases for rules are capable of withstanding judicial scrutiny. Professor E. Donald Elhott, former General Counsel of the Environmental Protection Agency, refers to this

* William Stamps Farish Professor of Law, University of Texas School of Law. B.A. 1971, Rice; J.D., 1974, University of Texas. The author would like to express his appreciation to the Carnegie Commission on Science, Technology, and Government for its support in the preparation of this Article. In particular, the efforts of Douglas M. Costle, Chairman of the Regulatory Subcommittee, and Jonathan Bender, staff haison, are appreeiated.

1. See Antonin Scalia, Back to Basics: Making Law Without Making Rules, Regulation, July/August 1981, at 25, 25 (characterizing the 1970s as the "era of rulemaking").

2. Kenneth C. Davis, Administrative Law Treatise $\S 6.15$, at 283 (1st ed. Supp. 1970). In 1970, Professor Davis opined that "[b]y and large, federal agencies should resort to rule making much niore than they do." Id. at 285; see also Federal Power Comm'n v. Texaco, Inc., 377 U.S. 33, 41-44 (1964) (stating that rulemaking is necessary to efficient regulation); United States v. Storer Broadcasting Co., 351 U.S. 192, 205 (1956) (noting that nuch effort goes into rulemaking to ensure efficiency, flexibility, and review procedures). According to Professor (now Justice) Scalia:

Rulemaking was ... thought to foster better government. It enabled an agency to set its own policy-making agenda, addressing particular issues when it wished instead of waiting

for them to be presented in the course of its case-by-case licensing, or ratemaking, or enforcement business. And it could decide a number of related policy issues together, instead of in the piecemeal fashion that adjudication tends to produce.

Scalia, supra note 1 , at 26.

3. Scalia, supra note 1, at 26-27; see also Richard J. Pierce, Jr., Unruly Judicial Review of Rulemaking, NAT. ResourCES \& ENV'T, Fall 1990, at 23, 23 ("In 1990, this ingenious device for policymaking is in danger of being relegated to a chapter in a legal history book."). 
troublesome phenomenon as the "ossification" of the rulemaking process, ${ }^{4}$ and many observers from across the political spectrum agree with him that it is one of the most serious problems currently facing regulatory agencies. ${ }^{5}$

It may have been predictable at the outset that the same forces that turned administrative adjudication into an exceedingly time-consuming and resource-intensive activity would be brought to bear on informal rulemaking as soon as its potential to facilitate public regulation of private conduct became apparent to affected econounic entities. ${ }^{6}$ Yet as advocates of regulatory relief learned during the first Reagan Administration, the same inertial forces that slow down the process of formulating and impleinenting new rules can impede ruleniaking to achieve deregulatory goals. ${ }^{7}$ The informal rulemaking process of the 1990s is so heavily laden with additional procedures, analytical requirements, and external review inechamisms that its superiority to case-bycase adjudication is not as apparent now as it was before it came into heavy use. Perhaps of even more concern to regulatees and the general public is recent evidence that agencies are beginning to seek out alternative, less participatory regulatory vehicles to circumvent the increasingly stiff and formalized structures of the informal rulemaking process.

While Professor Elliott's observations standing alone may sufficiently warrant an inquiry into the causes of and potential solutions to the "ossification" phenomenon, additional evidence of the increasing burdensoineness and rigidity of the informal rulemaking process is not hard to find. Part I of this Article examines soine of the existing evidence of the ossification of informal rulemaking. It also explores some of the

4. E. Donald Elliott, Remarks at the Symposium on "Assessing the Environmental Protection Agency After Twenty Years: Law, Politics, and Economics," at Duke University School of Law (Nov. 15, 1990).

5. See, e.g., Scalia, supra note 1 , at 26 ("the comparative advantages of rulemaking have eroded in recent years").

6. Matthew McCubbins, Roger Noll, and Barry Weingast plausibly suggest that burdensome and time-consuming agency structures and procedures help both the executive and the legislative branch to maintain control over an otherwise unaccountable bureaucracy. Matthew D. McCubbins et al., Structure and Process, Politics and Policy: Administrative Arrangements and the Political Control of Agencies, 75 VA. L. REv. 431, 442 (1989) ("Administrative procedures erect a barrier against an agency carrying out ... a fait accompli by forcing the agency to move slowly and publicly, giving politicians (informed by their constituents) time to act before the status quo is changed."). If this is true, then legislative and executive imposition of administrative structures and procedures aimed at slowing down the process enough to allow the political principals to keep track of agency policymaking should come as no surprise. See Michael Asimow, Nonlegislative Rulemaking and Regulatory Reform, 1985 DUKE L.J. 381, 424 ("Sometimes opponents of a new substantive program successfully negotiate for statutory provision of detailed procedures that, in practice, render the regulatory program cumbersome and unworkable.").

7. See Merrick Garland, Deregulation and Judicial Review, 98 HARv. L. Rev. 507, 508 (1985). 
adverse consequences of that phenomenon from the perspective of sound public policymaking. Part II discusses the causes of ossification. Specifically, it sets forth the current problems with procedural and analytical requirements, as well as with scientific and substantive review requirements. Finally, Part III examines various ossification avoidance devices. It identifies tools that will make informal rulemaking a more useful way for government to regulate private arrangements.

\section{THE OSSIFICATION OF INFORMAL RULEMAKING}

Although no detailed empirical studies exist on the comparative burdensomeness of informal rulemaking and alternative regulatory vehicles, it is difficult to disagree with the conclusion that it is much harder for an agency to promulgate a rule now than it was twenty years ago. Agency explanations for rules are far more lengthy and intricate than they were im the 1960s and early 1970s. The "concise general statement of basis and purpose" for the original primary and secondary ambient air quality standards promulgated under the Clean Air Act Amendments of 1970 consisted of a single page in the Federal Register when they were promulgated in $1971 .{ }^{8}$ The preamble to the 1987 revision of a simgle primary standard consumed 36 pages in the Federal Register ${ }^{9}$ and was supported by a 100-plus-page staff paper, a lengthy Regulatory Impact Analysis that cost the agency millions of dollars, and a multi-volume criteria document. ${ }^{10}$

The agencies also take much longer to write the lengthy preambles and technical support documents and to address public comments on proposed rules. ${ }^{11}$ The Occupational Safety and Health Admimistration (OSHA) in 1972 spent about six months froin inception to publication of

8. 36 Fed. Reg. 8186 (1971).

9. 52 Fed. Reg. 24,634 (1987).

10. See Environmental Protection Agency, Regulatory Impact Analysis on the National Ambient Air Quality Standards for Particulate Matter (1984); Environmental Protection Agency, Air Quality Criteria for Particulate Matter and Sulfur Oxides (Dec. 1982).

11. Professor Asimow observes that modern notice-and-comment rulemaking must overcome strong inertial forces:

To produce any new rule, whether legislative or noulegislative, an agency must incur the substantial bureaucratic costs of overcoming imertia. The internal process includes research, resolution of staff conflicts, informal consultation with interested outsiders, agreement upon precise language, consensus-building, and multilevel review. The flnancial and psychological costs of forging consensus within an agency on the contents of a new rule may be quite substantial.

Asimow, supra note 6, at 403-04 (citing ANTHONY Downs, INSIDE BUREAUCRACY 178-82 (1967)); see also Richard J. Pierce, Jr., Two Problems in Administrative Law: Political Polarity on the District of Columbia Circuit and Judicial Deterrence of Agency Rulemaking, 1988 DuKE L.J. 300, 301-02 ("[A]n agency must rcalistically conclude that making an important policy decision through the rulemaking process will require it to commit a signiflcant proportion of its scarce resources to that process for as much as a decade."). 
the final rule on its first occupational health standard for asbestos. Two of its next three health standards, a generic rule for fourteen carcinogens and a standard for vinyl chloride, took about one year, and nine inonths, respectively. The next three standards, for cotton dust, acrylonitrile, and arsenic, each took over three-and-one-half years. These last three standards were pronulgated during the relatively activist Carter Adıninistration when OSHA was anxious to write new rules to protect workers. ${ }^{12}$ Today, OSHA health standards rarely take less than five years to proinulgate.

For example, when the Environmental Protection Agency (EPA) was considering whether to refer the chemical 4,4' inethylendianiline to OSHA for regulation in 1983, the two agencies issued a joint advance notice of proposed rulemaking. ${ }^{13}$ After studying the public comments for three years and receiving a formal referral from EPA, ${ }^{14}$ OSHA initiated a negotiated rulemaking procedure in early $1986 .{ }^{15}$ With the help of a six-inonth extension, the negotiation committee issued a consensus report in July 1987, and OSHA expected to issue a proposed standard within ninety days. ${ }^{16}$ The agency, however, decided to refer the proposal to its Advisory Committee on Construction Safety and Health, which successfully requested the agency to defer its review until February $1988,{ }^{17}$ thus further delaying the publication of the proposal. OSHA then sent the proposal to the Office of Management and Budget (OMB), where it languished until September, at which point the upcoming election delayed inatters still further. The proposed standard was finally published in May 1989, six years after the original referral. ${ }^{18}$ The final rule was ultimately published on August 10, 1992.19

Inportant rulemaking mitiatives grind along at such a deliberate pace that they are often consigned to regulatory purgatory, never to be resurrected again. When the Federal Trade Cominission (FTC) began to issue industry-wide rules in 1962, it generally took one to two years from the promulgation of a notice of proposed rulemaking to a final rule.

12. See Elinor P. Schroeder \& Sidney A. Shapiro, Responses to Occupational Disease: The Role of Markets, Regulation, and Information, 72 GEO. L.J. 1231, 1305-09 (1984) (providing table of publication dates of health standards). The only aberration in this sequence was the standard for lead, which was initiated ni 1973, but not coinpleted until 1978.

13. See 48 Fed. Reg. 42,836 (1983).

14. 50 Fed. Reg. 27,674 (1985).

15. 51 Fed. Reg. 24,452 (1986).

16. OSHA Publishes Committee Recommendations, Expects to Issue Proposed Rule Within 90 Days, 17 O.S.H. Rep. (BNA) 239 (July 22, 1987).

17. Hazard Rule Should Cover Industry, Advisory Group Tells OSHA at Meeting, 17 O.S.H. Rep. (BNA) 935, 935 (Nov. 11, 1987).

18. 54 Fed. Reg. 20,672 (1989).

19. 57 Fed. Reg. 35,630 (1992). 
Although the courts ultimately upheld FTC's authority to promulgate such rules, ${ }^{20}$ Congress clarified that authority in the Magnuson-Moss Warranty/FTC Improvements Act."1 This Act provided for "hybrid rulemaking" that added somewhat to the minimal procedural requirements of the APA. Of the nineteen major rules and amendments proposed under this new authority during the latter part of the $1970 \mathrm{~s}^{22}$

20. National Petroleum Refiners Ass'n v. FTC, 482 F.2d 672 (D.C. Cir. 1973), cert. denied, 415 U.S. 951 (1974).

21. Pub. L. No. 93-637, 88 Stat. 2183 (1975) (codified as amended at 15 U.S.C. $\$ \$ 57$ a, 57b, and in other scattered sections of 15 U.S.C.).

22. Federal Trade Comm'N, 98th Cong., 2d Sess., FTC Review 155-66 (Comm. Print 98-cc 1984):

TABLE 1

FTC Trade Regulation Rules Since 1974

TIME From PRoposal to COMPLETION

Title

16 C.F.R. $\S 433$

Preservation of BuYers'

ClAIMS AND DEFENSES IN

CONSUMER INSTALLMENT SALES

16 C.F.R. $\$ 438$

PROPRIETARY VOCATIONAL AND

HOME STUDY SCHOOLS

16 C.F.R. $\$ 437$

FOOD ADVERTISING

16 C.F.R. $\S 444$

Credit Practices

16 C.F.R. $\S 441$

Mobile Homes Sales AND

SERVICE

16 C.F.R. $\$ 447$

Disclosure Regulations

CoNCERNINg Retall PRICES

FOR PRESCRIPTION DRUGS

16 C.F.R. $\$ 440$

HEARING AID INDUSTRY

16 C.F.R. $\$ 439$

Cellular Plastics Products;

Disclosure OF COMBUSTION

Characteristics IN

MARXETING AND CERTIFICATION

16 C.F.R. § 443

Health SPAS

16 C.F.R. $\S 453$

Funeral Industry Practices

16 C.F.R. $\$ 454$

ADVERTISING AND LABELING OF

PROTEIN SUPPLEMENTS

16 C.F.R. $\$ 450$

ADVERTISING FOR OVER-THE-

COUNTER DRUGS
Proposed

1/26/71

36 Fed. Reg. 1211

$8 / 15 / 74$

39 Fed. Reg. 29,385

$11 / 11 / 74$

39 Fed. Reg. 39,842

4/11/75

40 Fed. Reg. 16,347

5/29/75

40 Fed. Reg. 23,334

$6 / 4 / 75$

40 Fed. Reg. 24,031

$6 / 24 / 75$

40 Fed. Reg. 26,646

7/23/75

40 Fed. Reg. 30,842

Final

11/18/75

40 Fed. Reg. 53,506

$12 / 28 / 78$

43 Fed. Reg. 60,797

none

$3 / 1 / 84$

49 Fed. Reg. 7789

none

Time

58 months

52 months

107 months

$\infty$

Terminated 11/24/78

43 Fed. Reg. 54,951

none

Terminated $6 / 18 / 80$

45 Fed. Reg. 41,156

$8 / 18 / 75$

40 Fed. Reg. 34,615

8/29/75

40 Fed. Reg. 39,901

9/5/75

40 Fed. Reg. 41144

$11 / 11 / 75$

40 Fed. Reg. 52,631 none

$9 / 24 / 82$

47 Fed. Reg. 42,299

none

Terminated 5/1/81

46 Fed. Reg. 24,584 $\infty$

$\infty$

85 months

$\infty$ 
admittedly an activist time for the FTC, only seven were completed, ${ }^{23}$ and the average time to completion was $51 / 3$ years. ${ }^{24}$ Although many factors account for this poor production, including new leadership at FTC that was antithetical to ambitious consumer protection initiatives, even projects that were actively pursued by the Reagan Administration FTC moved at a ponderous pace. ${ }^{25}$

Once an agency has endured the considerable expense and turmoil of writing a rule, it has every incentive to leave well enough alone. Once the legal and political dust has settled, an agency is inclined to let sleeping dogs lie. Even when forced by statute to revisit existing rules, an agency is very reluctant to change them. For example, EPA has a statutory obligation to reexamine its national ambient air quality standards every five years, but it has rarely completed the process without the additional incentive of a court order. ${ }^{26}$ And when it does promulgate a revised standard, it tends to set the standard at or near existing levels, in part because of the difficulty of justifying any departures from the status

\begin{tabular}{|c|c|c|c|}
\hline $\begin{array}{l}16 \text { C.F.R. } \$ 423 \\
\text { CARE LABELING OF TEXTILE } \\
\text { WEARING APPAREL AND } \\
\text { CERTAIN PIECE GOODS AS } \\
\text { AMENDED }\end{array}$ & $\begin{array}{l}1 / 26 / 76 \\
41 \text { Fed. Reg. } 3747\end{array}$ & $\begin{array}{l}5 / 20 / 83 \\
48 \text { Fed. Reg. } 22,743\end{array}$ & 88 months \\
\hline $\begin{array}{l}16 \text { C.F.R. } \$ 455 \\
\text { USED MOTOR VEHICLE TRADE } \\
\text { REGULATION RULE }\end{array}$ & $\begin{array}{l}1 / 6 / 76 \\
41 \text { Fed. Reg. } 1089\end{array}$ & $\begin{array}{l}11 / 19 / 84 \\
49 \text { Fed. Reg. } 45,725\end{array}$ & 106 months \\
\hline $\begin{array}{l}16 \text { C.F.R. } \$ 456 \\
\text { OPHTHALMIC PRACTICE RULES }\end{array}$ & $\begin{array}{l}\text { 1/16/76 } \\
\text { 41 Fed. Reg. } 2399\end{array}$ & $\begin{array}{l}\text { 6/2/78 } \\
\text { 43 Fed. Reg. } 23,992\end{array}$ & 29 months \\
\hline $\begin{array}{l}16 \text { C.F.R. } \$ 451 \\
\text { ADVERTISING FOR OVER-THE- } \\
\text { COUNTER ANTACIDS }\end{array}$ & $\begin{array}{l}4 / 6 / 76 \\
41 \text { Fed. Reg. } 14,534\end{array}$ & none & \\
\hline $\begin{array}{l}16 \text { C.F.R. } \$ 460 \\
\text { LABELING AND ADVERTISING OF } \\
\text { HOME INSULATION }\end{array}$ & $\begin{array}{l}11 / 18 / 77 \\
42 \text { Fed. Reg. } 59,678\end{array}$ & $\begin{array}{l}8 / 27 / 79 \\
44 \text { Fed. Reg. } 50,242\end{array}$ & 21 months \\
\hline $\begin{array}{l}16 \text { C.F.R. \$ } 461 \\
\text { CHILDREN'S ADVERTISING }\end{array}$ & $\begin{array}{l}4 / 27 / 78 \\
43 \text { Fed. Reg. } 17,967\end{array}$ & $\begin{array}{l}\text { Terminated } 10 / 2 / 81 \\
46 \text { Fed. Reg. } 48,710\end{array}$ & \\
\hline $\begin{array}{l}16 \text { C.F.R. } \$ 457 \\
\text { STANDARDS AND CERTIFICATION }\end{array}$ & $\begin{array}{l}\text { 12/7/78 } \\
43 \text { Fed. Reg. } 57,269\end{array}$ & none & $\infty$ \\
\hline
\end{tabular}

Average Rulemaking Time for Those Proposed Rules That Became final Rules: 63 months ( 5 years and 3 months).

23. Four of the rulemakings were officially terminated, and seven have still not been completed. See Table 1, supra note 22.

24. See Table 1, supra note 22.

25. For example, after the D.C. Circuit remanded the Carter Administration's ophthalmic practices rule in 1980, American Optometric Ass'n v. FTC, 626 F.2d 896 (D.C. Cir. 1980), the Reagan FTC proposed a revised ophthalmic practice rule in April 1985, 50 Fed. Reg. 598 (1985). The final rule, however, was not completed until March 1989. 54 Fed. Reg. 10,304 (1989).

26. In June 1985, a district court in Spokane, Washington ordered EPA to issue a carbon monoxide ambient air quality standard by September 13. Eastern District Court of Washington Ordered $E P A$ to Issue a CO NAAQS, INSIDE EPA, June 21, 1985, at 4. In December 1985, a coalition of environmental groups and states sued EPA for failing to revise the ambient air quality standard for sulfur dioxide. States, Environmental Groups Sue EPA Citing Inadequate Sulphur Oxide Standards, 16 Env't Rep. (BNA) 1602 (Dec. 13, 1985). The Second Circuit held that the United States District 
quo. ${ }^{27}$ Similarly, although OSHA devoted most of its standard-setting efforts at the outset of the Reagan Administration to reexamining several rules, the final results did not differ in any significant regard from the existing regulations. ${ }^{28}$ Thus, an agency's general reluctance to revisit old rules may disserve both regulatees and regulatory beneficiaries. ${ }^{29}$

Simce most regulatory statutes were enacted to accomplish progressive public policy goals, the ossification of the informal rulemaking process hinders or defeats the agency's pursuit of those goals. To some extent, the fact that the air and waters of the United States are still polluted, workplaces still dangerous, motor vehicles still unsafe, and consumers still being deceived is attributable to the expense and burdensoineness of the informal rulemaking process. In addition to frustrating congressional policy goals, the ossification of the informal rulemaking process deprives it of one of its greatest virtues-administrative efficiency. ${ }^{30}$ When agencies expend twice as many resources to achieve the same results, the taxpayer is the ultimate loser. To be sure,

Court for the Southern District of New York had jurisdiction to order EPA to promulgate a standard. Environmental Defense Fund v. Thomas, 870 F.2d 892, 900 (2d Cir.), cert. denied, 493 U.S. 991 (1989).

27. At the end of a court-ordered reexamination of the carbon monoxide standard, EPA decided to retain the existing primary standard. 50 Fed. Reg. 37,484 (1985). After reexamining at length the standard for oxides of mitrogen, EPA decided in June 1985 to leave the standard at current levels. 50 Fed. Reg. 25,532 (1985). After studying the matter for six years, EPA in April 1988 proposed to retain the current standards for sulfur oxide. 53 Fed. Reg. 14,926 (1988). The agency still has not issued a final rule retaining the sulfur oxides standard at the current level. The revised nmbient air quality standard for particulates was set at about the same degree of stringency as the existing standard, even though the units of ineasurement were changed from total suspended particulates to particulate matter of less than or equal to 10 microns in diameter. 52 Fed. Reg. 24,634 (1987); see also Thomas O. McGarity, Reinventing Rationality: The Role of RegulaTORY ANALYSIS IN THE FEDERAL BUREAUCRACY 58 (1991). The amended standard for photocheinical oxidants in 1978 did reduce the stringency of the standard significantly, 44 Fed. Reg. 8202 (1979), but the agency has resisted suggestions that it should increase its stringency to former levels in light of new scientific data suggesting that the relaxation did not sufficiently proteet human health.

28. Two of the more important mitiatives were the reexaminations of the cotton dust and lead standards. In neither case did the agency depart significantly from the previous standard. See Thomas O. MCGARITY \& SidNey A. ShaPIRo, WoRkers AT RISK ch. 5 (forthcoining 1993).

29. In areas in which additional knowledge and expericnce are likely to yield more information justifying increased regulatory stringency, the reluctance to rewrite caused by the burdensomeness of the rulemaking process inay harm regulatory beneficiaries. More frequently, however, agencies resolve uncertainties in initial rulemaking initiatives to favor beneficiaries. In such areas, agencies' disinclination to revisit old rules in light of more recently available information indicating a reduced need for regulatory stringency may disfavor regulatees.

30. As Professor Pierce has noted:

Rulemaking enhances efficiency in three ways. It avoids the needless cost and delay of finding legislative facts through trial-type procedures; it eliminates the nced to relitigate policy issues in the context of disputes with no material differences in adjudicative facts; and, it yields much clearer "rules" than can be extracted from a decision resolving a specific dispute.

Pierce, supra note 11 , at 308. 
other societal goals, such as fairness, allocative efficiency, and factual accuracy, may demand more deliberative rulemaking procedures, analytical exercises, and other quality control requirements. ${ }^{31}$ And the extent to which a more burdensome rulemaking process reflects an appropriate balance among these competing goals is a matter on which reasonable minds can differ. Nevertheless, the fact that the ossification of the informal rulemaking process frustrates statutory goals is a primary reason for inquiring into the causes of and cures for the ossification phenomenon.

The ossification of the informal rulemaking process also reduces agency incentives to experiment with flexible or temporary rules. Experimentation is welcome $\mathrm{m}$ an atmosphere $\mathrm{m}$ which rules can be undone if they do not produce the anticipated changes or cause unanticipated side effects. But experimentation is riskier in an atmosphere in which any change is likely to be irreversible. This inflexibility is especially unfortunate in the context of programs in which agencies must regulate on the "frontiers of scientific knowledge" with particularly treacherous "facts." 32 New scientific discoveries can erode the technical basis for a rule that was promulgated only a few years ago. New technologies can make available fresh alternatives that were not considered at the time the agency first examined the issues. However, the agencies are understandably reluctant to rock the boat when to do so requires an enormously expensive rulemaking in which a successful outcome is by no means assured.

For example, when Congress enacted the Occupational Safety and Health Act, it told OSHA to examine existing exposure guidelines established by private standard-setting organizations and to promulgate them as "national consensus standards" withni sixty days. ${ }^{33}$ Many of the almost 400 Permissible Exposure Limitations (PELs) that resulted from this speedy process eventually became obsolete as new studies revealed that certam chemicals were more or less hazardous than indicated in the late 1960s. Whereas the industry and quasi-governmental organizations continued to change their voluntary guidehnes, OSHA was reluctant to amend the PELs, beheving that they could be modified only through the exceedingly burdensome process of promulgating full-fledged occupational health standards. As a result, the PELs remained unaltered for almost two decades, until OSHA decided to attempt to avoid case-by-

31. See Natural Resources Defeuse Council, Inc. v. EPA, 822 F.2d 104, 113 (D.C. Cir. 1987) ("It scarcely needs repeating that statutes are rarely, if ever, unidimensionally directed toward achieviug or vindicating a single public policy.").

32. Industrial Union Dep't, AFL-CIO v. Hodgson, 499 F.2d 467, 474 (D.C. Cir. 1974).

33. Pub. L. No. 91-596, § 6, 84 Stat. 1593, 1593 (1970) (codified at 29 U.S.C $§ \S 651,655$ (a) (1988)). 
case rulemaking with a generic PEL update rule. ${ }^{34}$ Even that effort, however, would probably not have been pursued to its largely successful completion had the Assistant Secretary for Occupational Safety and Health not made it a centerpiece of his administration. ${ }^{35}$

Frustrated agencies are beginning to explore techniques for avoiding notice-and-comment rulemaking altogether, such as estabhishing rules in adjudications. ${ }^{36}$ After an intensive study of the rulemaking process in the National Highway Traffic Safety Administration (NHTSA), Professors Mashaw and Harfst observed that NHTSA had used informal rulemaking fairly successfully from its inception in 1966 until about 1974. ${ }^{37}$ Since the mid-1970s, however, NHTSA has concentrated on its alternative statutory power to force the recall of motor vehicles that contain "defects" related to safety performance. Mashaw and Harfst pessimistically concluded that NHTSA "retreated to a traditional form of case-by-case adjudication, which requires little, if any, technological sophistication and which has no known effects on vehicle safety." 38 To the extent that agencies establish rules $\mathrm{m}$ adjudications in order to avoid $\mathrm{m}$ formal rulemaking, regulatees are not put on notice of the standards of conduct that such agencies are applymg to thein. As a result, both regulatees and regulatory beneficiaries are deprived of the open opportunity that informal rulemaking provides to influence the agencies' thinking. ${ }^{39}$

Perhaps more troublesome to the goals of open government is the increasing tendency of agencies to engage in "nonrule rulemaking" through relatively less formal devices such as policy statements, interpretative rules, inanuals, and other informal devices. Although informal guidance docuinents and technical manuals are a necessary part of a complex administrative regime, they are promulgated without the benefit of comments by an interested public. For example, the Resource Conservation and Recovery Act ${ }^{40}$ delegates to EPA the critical functions of defining "hazardous waste" and specifying the methods for determining whether a waste is hazardous. ${ }^{41}$ Since EPA's regulations for

34. See McGariry \& SHAPIRo, supra note 28, ch. 9.

35. Id.

36. See Pierce, supra note 11, at 301; Terence Scanlon \& Robert Rogowsky, Back Door Rulemaking: A View from the CPSC, REGULATION, July/Aug. 1984, at 27.

37. Jerry L. Mashaw \& David L. Harfst, Regulation and Legal Culture: The Case of Motor Vehicle Safety, 4 YALE J. on REg. 257, 263 (1987).

38. Id.; see JeRry L. Mashaw \& David L. Harfst, The Struggle for Auto Safety 14771 (1990).

39. See Scalia, supra note 1 , at 26 .

40. 42 U.S.C. $\S \S 6901-6987$ (1988).

41. 42 U.S.C. $\S 6921$. 
"characteristic" hazardous wastes ${ }^{42}$ only occasionally specify a particular test method for determining whether a waste passes a threshold criteria, ${ }^{43}$ the generator of the waste is left to come up with its own testing methods to determine whether the criteria are exceeded. ${ }^{44}$ To aid potential generators im this regard, EPA has written a two-inch-thick "sampling and analysis manual" entitled "Test Methods for Evaluating Solid Waste," recognized by those in the know as "SW-846."45 Although EPA originally promulgated SW-846 as an informal rule, the methods in SW846 are periodically updated without notice-and-comment to incorporate new scientific techniques.

The EPA's rulemaking process, however, has become so ossified that it cannot keep up with the changes. Hence, if one writes to EPA and requests a copy of SW-846, EPA will send "Final Update I" to the Third Edition of SW-846, which was published in November 1990. The original Third Edition was published in November 1986, and EPA issued a notice of proposed rulemaking in January 1989 to make that version of SW-846 binding (to the extent that the agency's regulations made particular methods legally binding). ${ }^{46}$ That proposal, however, has not been finalized. ${ }^{47}$ Therefore, the legally binding version of SW-846 is "Updates I and II" of the Second Edition of SW-846, which was published in 1982 and updated in 1984 and 1985. For "guidance purposes," however, Final

42. 40 C.F.R. $\$ \$ 261.20$ to .24 (1991). EPA has also listed a large number of hazardous wastes by source and by chemical compound. Id. $\S \S 261.30$ to .35 . In contrast to generators of characteristic hazardous wastes, generators of histed wastes rarely need to undertake further testing. If their wastes are on the list, they are hazardous wastes.

43. See, e.., id. § 261.22(a)(1) (specifying "Method 5.2 in 'Test Methods for the Evaluation of Sold Waste, Physical/Chemical Methods" "or an "equivalent test method" for determining the $\mathrm{pH}$ of a substance); id. § 261.22(a)(2) (specifying "the test method specified in NACE (National Association of Corrosion Engineers) Standard TM-01-69 as standardized in 'Test Methods for the Evaluation of Sohid Waste, Physical/Chemical Methods" "or an "equivalent test method" for determining the rate at which a substance corrodes steel).

44. See id. §262.11.

45. I.A Environmental Protection Agency, Test Methods for Evaluating Solid Waste: Laboratory Manual Physical/Chemical Methods preface-1 (3d ed. 1986). Although a few of the testing methods detailed in SW-346 are incorporated by reference in the regulations specifying the criteria for testing whether wastes possess the characteristics that make them hazardous (so-called "characteristic" wastes), see supra note 42 , most of the testing methods are offered for "guidance" purposes. In other words, a generator is free to use any testing method that it can justify as aceurate and reliable, but if it follows the procedures specified in the manual, it does not risk a fine or imprisonment.

46. 54 Fed. Reg. 3212 (1989); see also 54 Fed. Reg. 40,260 (1989) (finalizing rule for 47 of the testing methods contained in the Third Edition of SW-846).

47. See 55 Fed. Reg. 4440 (1990) (reopening the comment period on the January 23, 1989 proposal). 
Update I of the Third Edition is the relevant document. ${ }^{48}$ The Government Printing Office (GPO) will gladly sell a copy of Final Update I to the generator for $\$ 110.49$ If the generator makes its request very clear, EPA will send Updates I and II of the Second Edition, which is legally binding to the extent that specific methods are incorporated by reference in the regulations, but superseded by the Third Edition for "guidance purposes." The document that EPA sends, however, will contain the following warning:

\section{Attention}

As noted in the NTIS [National Technical Information Service] announcement, portions of this Report are not legible. However, it is the best reproduction available from the copy sent to NTIS.

If all this leads the frustrated potential regulatee to wonder whether "secret law" is at play here, those fears may be well founded. The "guidance" contained in the Second Edition of SW-846 as updated by Updates I and II does not prescribe any particular method for extracting liquids from solids, semi-solids, and semi-hiquids for purposes of the corrosivity characteristic. The original 1986 version of the Third Edition of SW-846 states: "Use Method 9095, Paint Filter Liquids Test, Chapter Six, to determine free hiquid."50 Then, buried in a June 1986 preamble to a rule addressing a different characteristic (that of toxicity), a very diligent reader of the Federal Register would find a strong indication that EPA no longer looked with favor upon Method 9095 for separating hquids from other substances, at least in the context of toxicity. Finally, upon reading Final Update $I$ to the Third Edition, a generator (who might have been relying upon Method 9095 for testing its wastes for corrosivity) would discover (perhaps to its dismay) that the above-quoted sentence was no longer included in the text of the corrosivity chapter. The regulatee is thus left to guess, with large fines and even imprisonment hanging in the balance, whether to continue using Method 9095 or to adopt soine perhaps more expensive test for purposes of corrosivity testing. In the absence of a specification of a particular separation method in the regulations (which are promulgated through notice-andcomment procedures), the generator may use any scientifically valid separation method. However, the rather clear negative implication of the

48. The careful reader of the Code of Federal Regulations will discover in a footnote to 40 C.F.R. $\S 260.11$ (1991) the following explanation of the legal status of SW-846: "The Agency notes that, for guidance purposes, the Third Edition and its Revision I supersede the Second Edition and its Updates I and II. However, for regulatory purposes, the Second Edition and Updates I and II remain in effect ...."

49. 40 C.F.R. $§ 260.11$ (1991).

50. I.C Environmental Protection Agency, supra note 45, at seven-3. 
deletion of the previous command to use Method 9095 would certainly caution against continued use of that method.

The preceding example should demonstrate that notice-and-comment rulemaking procedures provide an element of fairness that is wholly lacking when an agency issues a guidance inanual and announces that it plans to adhere to it or to some future manifestation of it in future enforcement actions. ${ }^{51}$ Neither regulatees, who are often put in the position of having to coinply with these untested requirements or else risk heavy penalties or losses of important permits, nor public interest groups, who have no opportunity to participate in the resolution of important policy questions, have welcomed this change. ${ }^{52}$

\section{Causes of Ossification}

The ossification phenomenon would be easier to understand if it were attributable to the natural lethargy of chronically underfunded bureaucracies, ${ }^{53}$ but that simple explanation does not tell the whole story. Certainly, if more resources were plowed into rulemaking initiatives, the agencies would be less reluctant to undertake controversial rulemaking projects, to revisit old rules, and to write inore flexible rules in the first place. However, even substantially greater rulemaking resources will make little difference if the underlying inertial forces remain.

The decisionmaking model embodied in section 553 of the APA is an exceedingly simple one. The agency inust put the public on notice of the nature of the issues to be resolved, give interested persons an opportumity to submit written comments, and explain the final rule in a concise general statement of basis and purpose. As originally conceived, this

51. See Pierce, supra note 11, at 308-09 (informal rulemaking "provides affected parties with clearer notice of what conduct is permissible and impermissible; it avoids the widely disparate temporal impact of agency policy decisions made and implemented through ad hoc adjudication; and, it allows all potentially affected segments of the public to participate in the process of determining the rules that will govern their conduct and affect their lives").

52. See Robert A. Anthony, Interpretive Rules, Policy Statements, Guidances, Manuals, and the Like-Should Federal Agencies Use Them to Bind the Public?, 41 DUkE L.J. 1311 (1992). According to the executive director of the Business Council on the Reduction of Paperwork:

You are seeing, in things like handbooks and policy manuals and declarations of intent, new and innovative ways that agencies, attempting to get their job done, are ignoring their responsibilities under the Paperwork Reduction Act, the Regulatory Flexibility Act and the Administrative Procedure Act, and the president's executive orders to include other agencies and the American public.

Vice President's Regulatory Review Memo Draws Both Praise and Criticism, BNA WASH. INSIDER, Apr. 15, 1991, available in LEXIS, BNA Library, BNAWI File (statement of Mr. Robert Coakley).

53. See Neil R. Eisner, Agency Delay in Informal Rulemaking, 3 ADMIN. L.J. 7, 8 (1989) (attributing rulemaking delays in some part to "laziness or ineptitude on the part of the agency (e.g., poor drafting or analysis, inadequate control of rulemaking schedules, or the failure to consider applicable requirements, all of which may lead to problems during the internal review stage)"). 
bare-bones procedure provided few opportunities for obfuscation and obstruction. Yet for several reasons the process has acquired an "owlish" coniplexity that would surely cause its early proponents chagrin.

First, informal rulemaking has to some extent been a victim of its own success. Because it was imitially so efficient in forewarning individuals and groups forewarning about how the agency was planning to affect them, it has provided powerful political constituencies with ample opportunity to mobilize agamst individual rulemaking imitiatives. The political battleground has thus shifted from the legislature to the bureaucracy. ${ }^{54}$ When rulemaking is aimed at advancing progressive social agendas, regulatees and their trade associations have fiercely resisted the rulemnaking process, seeking to lard it up witlı procedural, structural, and analytical trappings that have the predictable effect of slowing down the agency. ${ }^{55}$ When the goal of rulemaking is to facilitate the use and developnent of fragile public resources or the licensimg of potentially dangerous new technologies, environmental and consumer groups have aggressively sought similar procedural, structural, and analytical protections. ${ }^{56}$

Second, informal rulemaking has evolved im an enviroument of intense institutional competition. Congress and the President have been vying for control over this important policymaking tool. Indeed, during the last two decades the institutional battle has taken on an almost partisan appearance, as the Republican Party has tended to doininate the executive branch while the Deniocratic Party lias continued to control Congress. ${ }^{57}$ Even the judiciary, albeit to a more limited extent, has staked out a doniam of influence over the informal ruleniaking process. Whether that influence has waxed or waned as Republican nominees

54. See Richard B. Stewart, The Reformation of American Administrative Law, 88 HARV. L. REV. 1669, 1684-85 (1975); see also Eisner, supra note 53, at 8 (attributing ruleinaking delays in part to "political pressure or action by private parties who would benefit from delay").

55. See, e.g., Portland Ceinent Ass'n v. Ruckelshaus, 486 F.2d 375, 394 (D.C. Cir. 1973) (agency must respond to public comments that pass a "threshold requirement of materiality"), cert. denied, 417 U.S. 921 (1974); Kennecott Copper Corp. v. EPA, 462 F.2d 846 (D.C. Cir. 1972) (remanding for further explanation due to "nagging problems" with the agency's explanation for its rule).

56. See, e.g., Vermont Yankee Nuclear Power Corp. v. Natural Resources Defense Council, Inc., 435 U.S. 519 (1978) (environinental group seeking greater procedural protections in informal ruleunaking); Kleppe v. Sierra Club, 427 U.S. 390 (1976) (environmental group seeking greater analytical proteetions under the National Environmental Policy Act); Warm Springs Dam Task Force v. Gribble, 621 F.2d 1017 (9th Cir. 1980) (environmental group seeking EPA comment on environmental inpact statement prepared by developinent-oriented agency).

57. See Administrative Law Symposium: Question \& Answer with Professors Elliott, Strauss, and Sunstein, 1989 DUKE L.J. 538, 554 ("One of the situations that faces the country today and inay be endemic for our future is that we have a Republican presidency and Republican judiciary lined up against a Democratic Congress.") (statement of Peter L. Strauss). 
have come to dominate the federal judiciary is a fascinating empirical question that is beyond the scope of this Article.

Third, modern informal rulemaking must often resolve extremely complex scientific and economic issues in the midst of daunting uncertaimties. Although the theoretical rationale for creating regulatory agencies is to lodge decisionmaking power in the hands of experts, the scientific and technical needs of modern informal rulemaking have in many cases outstripped the expert resources of the agencies themselves. Agencies therefore have often solicited advice from neutral outside scientists. ${ }^{58}$ At the same timie, opponents of regulation, convinced that the scientific advisory apparatus will interject a greater degree of caution into the rulemaking process, have pressed agencies to incorporate outside expert advice at every juncture in the decisionmaking process. Thus the scientific advisory apparatus has both slowed down the ruleinaking process and divested agencies of a certain degree of discretion to press the process forward toward particular policy-dominated outcomes.

Fourth, the modern rulemaking process has evolved in the historical context of unprecedented public distrust of the executive branch. An unbroken strimg of disappointing breaches of public trust stretching froin Watergate to the Iran-Contra scandal has precipitated a cynical skepticism about administrative exercises of discretion. None of the important private and institutional actors involved im modern informal rulemaking trust the agencies to make good decisions absent outside review inecharisms aimed at limiting their discretion. This raises the troubling question of whether ossification is an inevitable side effect of the medicine that our society prescribes to cure abuse of adiniristrative discretion. If so, then we must admit the possibility of a tradeoff between increased regulatory flexibility and bureaucratic accountability.

\section{A. Procedural Requirements}

Informal rulenaking was originally desigued to avoid the procedural quagmires that had ensnared formal rulemaking and adjudication. Agencies that elected to make broad policy through informal rulemaking would not be subject to timie-consuming discovery, unnecessary rules of evidence, and wasteful cross-examination. ${ }^{59}$ The agencies, not the parties before the agencies, could "run the show," as long as they were able at the end of the process to prepare explanations capable of withstanding "arbitrary and capricious" judicial review.

58. See Nicholas A. Ashford, Advisory Committees in OSHA and EPA: Their Use in Regulatory Decisionmaking, 9 SCI. TECH. \& HUM. VALUEs 72, 73 (1984); infra Part II(C).

59. See David L. Shapiro, The Choice of Rulemaking or Adjudication in the Development of Administrative Policy, 78 HARv. L. REv. 921, 936-37 (1965). 
To a remarkable degree informal rulemaking has retained its procedural simphicity through the years. For a brief time there was talk among soine D.C. Circuit judges and sympathetic academics about the virtues of judicially imposed "hybrid rulemaking" procedures that would ensure that the agencies adequately "ventilated" the technical issues. 60 However, this incipient movenient was nipped in the bud by the Supreme Court in 1978 in its famous Vermont Yankee opinion. ${ }^{61}$ Although the executive branch is generally free to impose additional procedures upon itself, it has rarely elected to do so. ${ }^{62}$ Congress has been somewhat nore active, imposing hybrid procedure upon particular agencies on a rather ad hoc basis. ${ }^{63}$ Congress had considered inore thoroughgoing procedural innovations im ominibus regulatory reform legislation in the early $1980 \mathrm{~s},{ }^{64}$ but nothing caine of those efforts.

Thus the ossification of the rulemaking process cannot be explained by the accretion of procedural requirenients to the bare minimuin of section 553, as very few additional procedures have in fact been added. Even when agencies provide for more procedure, as OSHA and FTC have traditionally done, very hittle of the time consumed in the rulemaking process can be attributed to time spent in hearings. ${ }^{65} \mathrm{We}$ nust therefore look elsewhere for the causes of ossification.

60. Stephen F. Williams, "Hybrid Rulemaking" Under the Administrative Procedure Act: A Legal and Empirical Analysis, 42 U. CHI. L. REV. 401,402 (1975); see also Martin Shapiro, Administrative Discretion: The Next Stage, 92 YALE L.J. 1487, 1488 (1983) ('During the 1960's and 1970's, the courts, led by the Court of Appeals for the D.C. Circuit, caught up to the substantive reality of greatly increased rulemaking by writing a detailed, judge-made code of administrative procedure for rulemaking.").

61. Vermont Yankee Nuclear Power Corp. v. Natural Resources Defense Council, Inc., 435 U.S. 519 (1978).

62. One such example is the Regulatory Program of the United States, a procedure for putting potential regulatees and beneficiaries on notice of upcoming rulemaking initiatives. Exec. Order No. 12,498, 3 C.F.R. 323 (Comp. 1985), reprinted in 5 U.S.C. $\$ 601$ note (1988). Because an agency nuay not ordimarily begin a rulemaking initiative that is not on this regulatory agenda, the program demands that agencies engage in some ninimal long-range planning. Id. It is not hikely, however, that many agencies delay or abandon rulemaking initiatives nierely to avoid this small amount of additional paperwork.

63. See, e.g., 15 U.S.C. $\S 57 a(b),(c)$, (d) (1988) (specifying procedures for rulemaking by the Federal Trade Commission that go beyond the requirements of the APA); 15 U.S.C. \$ 2058(a), (b) (1988) (specifying the contents of the notice of proposed rulemaking, adding procedural requirements to those of section 553, and requiring that Consumer Product Safety Commission rulemakings be terminated upon certain conditions); 42 U.S.C. $\$ 7607$ (d) (1988) (specifying procedures for certain rulemakings under the Clean Air Act that go beyond the requirements of the APA). See generally Scalia, supra note 1 , at 27-28.

64. See Regulatory Reform Act: Hearings on S. 1080 Before the Subcomm. on Regulatory Reform of the Senate Comm. on the Judiciary, 97th Cong., 1st Sess. (1981).

65. See Thomas O. McGarity, OSHA's Generic Carcinogen Policy: Rule Making Under Scientific and Legal Uncertainty, in LAW AND SCIENCE IN COLlabORATION 55, 76-77 (J.D. Nyhart \& Milton M. Carrow eds., 1983). 


\section{B. Analytical Requirements}

1. Judicially Imposed Analytical Requirements. Despite the Supreme Court's mjunction in Vermont Yankee that the lower courts not burden agencies with additional procedural requirements, the notion persists that agencies engaged in rulemaking must have reasons for doing what they do, and that those reasons must have reference to a "ruleinaking record." 66 The statutory underpinning for this idea is probably the APA requirement that agencies must attach a "concise general statement of basis and purpose" to final rules. But this modest obligation has blossomed into a requirement that agencies provide a "reasoned explanation" for rules ${ }^{67}$ and that they rationally respond to outside comments passing a "threshold requirement of materiality."68 Although not especially burdensome in theory, these additional analytical requirements invite abuse by regulatees who hire consultants and lawyers to pick apart the agencies' preambles and background documents and launch blunderbuss attacks on every detail of the legal and teclinical bases for the agencies' rules. To the extent that reviewing courts vigorously police these requirements, the agencies cannot afford to allow any of the multifaceted attacks to go unanswered for fear that courts will reinand to them to respond to particular comments. ${ }^{69}$

66. Justice Scalia argues that these additional analytical requirements go beyond the minimum requirements of the APA:

The courts have attached many procedural requirements not explicit in the APA. These include the requirements that the agency publish and permit the public to comment on all data and studies on which it intends significantly to rely, and that the agency justify the rule in detail and respond to all substantial objections raised by the public comments.

Scalia, supra note 1 , at 26.

67. Although the "reasoned explanation" requirement is for the inost part judicially imposed, some agency statutes specifically require that agencies articulate reasons for their rules. See, e.g., Clean Air Act, 42 U.S.C. $\$ 7607$ (d) (1988).

Shapiro and Levy argue that the requirement that agencies explain themselves is the primary modern vehicle for constraining agency discretion:

By requiring a rational explanation for their actions, the Court seeks to put administrative agencies in the same framework that legal process scholars once thought applicable only to courts. This perspective argues that political and personal motivations influencing legal decisionmaking can be checked if judges are expected to give a "reasoned elaboration" for their actions according to norms of consistent, neutral and candid decisional processes. Similarly, rationalism requires agencies to give a "reasoned elaboration" demonstrating that their decisions serve the statutory ends for which they were created.

Sidney A. Shapiro \& Richard E. Levy, Heightened Scrutiny of the Fourth Branch: Separation of Powers and the Requirement of Adequate Reasons for Agency Decisions, 1987 DUKE L.J. 387, 412 (footnotes omitted).

68. Portland Cement Ass'n v. Ruckelshaus, 486 F.2d 375, 394 (D.C. Cir. 1973), cert. denied, 417 U.S. 921 (1974); see James V. Delong, Informal Rulemaking and the Integration of Law and Policy, 65 VA. L. Rev. 257, 271 (1979); Colin S. Diver, Policy-Making Paradigms in Administrative Law, 95 HARV. L. REv. 393, $411-19$ (1981) (showing how courts played role in imposing "comprehensive analytical approach" requirements on agencies).

69. See Pierce, supra note 11, at $\mathbf{3 1 0}$ ("In order to survive judicial review, an agency's "concise general' statement of basis and purpose must dcal comprehensively and in detail with each issue 
There is a genuine danger of judicial overreaching in this analytical review function: Reinanding for failure to respond to an outside cominent is an easy way for a court to dispose of a rulemaking challenge without appearing to extend itself beyond the range of its institutional coinpetence. In remanding for further analysis, the court is not ruling that the agency is wrong or irrational; it is merely holding that the agency's analysis is incomplete. ${ }^{70}$ Yet what the agency hears is that its explanations must be exceedingly thoroughgoing in every regard, or else its rulemaking initiatives may be sent back to the drawing board. Savvy program managers know that in the coinplex and constantly shifting institutional environment of modern rulemaking, a trip back to the drawing board can send the project spinning off in odd directions or, worse, can consign it to obhivion as the agency's limited staff resources are coinmitted to other projects, institutional inemory fades, and more immediate priorities press old rulemaking mitiatives to the botto1n of the agenda. The key to successful rulemaking is therefore to inake every effort to render the rule capable of withstanding the inost strenuous possible judicial scrutiny the first tinie around. As a result, the process of assimilating the record and drafting the preambles to proposed and final rules may well be the most tinie-consuming aspect of informal ruleinaking. ${ }^{71}$ The prospect of having to go through the Herculean effort of asseinbling the record and drafting a preainble capable of meeting judicial requirements for written justification mipel the agencies to seek ways to avoid rulemaking.

The courts can also inipose analytical requirements in a inore direct way by reading into agency statutes analytical obhgations not obvious in Congress's words. The Supreme Court deftly accomphished this in the Benzene case when it remanded OSHA's attempt to reduce worker exposure to benzene froin ten parts per million to one part per million. ${ }^{72}$

raised in coinments, no inatter how trivial that issue appears to the agency."); Mashaw \& Harfst, supra note 37 , at 282 (describing agency responses to the "full court press" in light of judicial requirements that the agency respond to every serious comment).

70. See Diver, supra note 68 , at 427 (noting that "the implicit distinction between the substantive correctness of the policy judgment and the adequacy of the offered explanation can, in the hands of a comprehensive rationalist, shrink to nothing").

71. See Pierce, supra note 3 , at 23 (noting that "judicial demands that agencies employ a synoptic approach to the fact-finding and reasoning process leading to a policy decision have so increased the resources that agencies inust devote to a rulemaking, the years required to complete a rulemaking, and the probability of judicial reversal at the end of that long and expensive process, that inany agencies have abandoned their prior efforts at a systematic policymaking.").

72. Industrial Union Dep't, AFL-CIO v. American Petroleum Inst., 448 U.S. 607 (1980). The Court focused on the defirition of "occupational safety and health standard" in $\S 3(8)$ of the Occupational Safety and Health Act, which Congress said was "a standard which requires conditions, or the adoption or use of one or more practices, mcans, methods, operations, or processes, reasonably necessary or appropriate to provide safe or healthful employment and places of employment." 29 
Writing for a plurality of only three Justices, Justice Stevens found that the agency had skipped an analytical step when it determined that exposure to carcinogens in the workplace should automatically be reduced to the lowest "feasible" level. ${ }^{73}$ According to Justice Stevens, inplicit in the word "safe" m OSHA's statute was a requirement that it make a threshold determination that existing exposures of employees to a chemical in the workplace present a "significant risk" of harm. At the same time, the Court suggested that mathematical risk assessment models were available to OSHA for use in making these "significant risk" threshold determinations. ${ }^{74}$ The Court thus found the words "significant risk" in a statute that did not use those words im order to require the agency to engage in a particular analytical methodology (risk assessment) the statute did not exphicitly require. ${ }^{75}$

U.S.C. $\S 652(8)$ (1988). The Court recognized that $\S 6(b)(5)$ of the Act, addressing "toxic materials or harmful physical agents" in particular, required the agency to "set the standard which most adequately assures, to the extent feasible, ou the basis of the best available evidence, that no employee will suffer material impairment of hcalth or functional capacity even if such employee has regular exposure to the hazard dealt with by such standard for the period of his working life." 448 U.S. at 612; see 29 U.S.C. $\S 655$ (b)(5) (1988). OSHA believed that in the particular ease of carcinogens, where a "no-effeet" level could not be determined, $\S 6(b)(5)$ required the standard to be set at the lowest "feasible" level, whether or not it posed a high risk at those levels and regardless of whether the "value" of the risks eliminated exceeded the "cost" of eliminating them.

73. 448 U.S. at 613-14.

74. The oue example that the plurality opinion provided demonstrated rather clearly that the author of the opimion did not understand the concept of environmental risk assessinent. Justice Stevens, by way of explanation, offered the following example:

Some risks are plainly acceptable and others are plainly unacceptable. If, for example, the odds are one in a billion that a person will die from cancer by taking a drink of chlorinated water, the risk clearly could not be considered significant. On the other hand, if the odds are one in a thousand that regular mhalation of gasoline vapors that are $2 \%$ benzene will be fatal, a reasonable person might well consider the risk significant and take appropriate steps to decrease or eliminate it.

Id. at 655. The example is an ideal illnstration of a confused approach to risk assessinent in the public health context. Drinking chlorimated water is an activity engaged in by practically everyone in American society. If 250 million Americans drink four glasses of water a day and are exposed to a one in a billion risk each time, then an average of one cancer per day will result. This amounts to about 365 cancers per year, a number that reasonable people might find to be "significant." Justice Stevens's example of a significant risk is harder to address from a public health perspective, because he neglected to provide two important pieces of information-the length of exposure that would result in a cancer and the number of persons who regularly breathe gasoline vapors. If we assume that exposure for a year presents a one in a thousand risk and that two einployees in each of the approximately 200,000 service stations in America are regularly exposed to benzene, then a one in a thousand risk would yield 400 cancers per year, a number that is not meaningfully different from the 365 cancers per year that Justice Stevens found to be clearly insignificant.

75. See Diver, supra note 68 , at 426 (referring to the "significant risk" test as "debatable statutory interpretation"). For other critiques of the Benzene case, see Howard A. Latin, The "Significance" of Toxic Health Risks: An Essay on Legal Decisionmaking Under Uncertainty, 10 EcoLOGY L.Q. 339 (1982); William H. Rodgers, Jr., Judicial Review of Risk Assessments: The Role of Decision Theory in Unscrambling the Benzene Decision, 11 ENVTL. L. 301 (1981); Susan Rose-Ackerman, Progressive Law and Economics-And the New Administrative Law, 98 YALE L.J. 341, 364-66 
Although it is generally a good idea for agencies to analyze carefully the consequences of proposed rules on the public and on regulatees, the discovery of a new requirement for an additional analytical methodology midway through the process of implementing a statutory command can hamstring a regulatory program. ${ }^{76}$ The Benzene decision, for example, completely disrupted OSHA's ongoing attempt to promulgate a comprehensive Generic Carcinogen Pohicy to regulate workplace exposure to carcinogenic substances on a generic basis. ${ }^{77}$ The perverse impact of the Benzene decision on individual rulemakings became apparent not inany years later when a union petitioned the agency to promulgate an emergency temporary standard (ETS) for formaldehyde. A then-recently prepared risk assessment based upon animal carcinogenesis studies had projected a 1.5 -im-10,000 risk of contracting cancer "for the great majority of workers" who were exposed to formaldehyde at levels lower than the 3 ppin standard. ${ }^{78}$ OSHA concluded that this risk did not approach the 1-in-1000 risk that the Supreme Court in the Benzene case suggested might constitute a significant risk. ${ }^{79}$ OSHA further found that "[e]ven the 'minority' of workers exposed to levels near the existing three parts per million exposure limit face 'ouly a four in 1,000 risk-a level not elevated dramatically above the Supreme Court's benchmark for perinanent rulemaking." "80 OSHA engaged in this exceedingly precise analysis with full knowledge that the estimates provided by existing risk assessment models could vary millionfold, depending upon the model selected. Nevertheless, the perceived need to employ quantitative risk assessment techniques to analyze its decision led OSHA to conclude that no ETS for formaldehyde was required. ${ }^{81}$

2. Congressionally Imposed Analytical Requirements. Congress occasionally requires that agencies engage in particular analytical exercises to form the underlying basis for their rules. For exaunple, when EPA promulgates regulations estabhishing national effluent limitations for industrial point source categories based on "best conventional control technology," it must demonstrate that it has analyzed the cost of taking a unit of pollution out of an industrial effluent stream using the prescribed

(1988). For commentary generally supportive of the Benzene case, see Cass R. Sunstein, On the Costs and Benefits of Aggressive Judicial Réview of Agency Action, 1989 DuKE L.J. 522, 529.

76. See Shapiro, supra note 60 , at 1508 (reading the Benzene case as a judicial attempt to read limitations on agency discretion into a statute).

77. See McGarity, supra note 65, at 65-66.

78. Evidence of "Grave Risk" Lacking for Emergency Formaldehyde Rule, DOL Says, 13 O.S.H. Rep. (BNA) 663, 663 (Nov. 17, 1983).

79. Id.

80. Id.

81. Id. 
technology in comparison with the cost of removing an equivalent unit of pollution froin a municipal sewage treatment works. The agency must also coinpare the incremental cost of the prescribed technology with the mcremental cost of installing the somewhat less stringent "best practicable control technology."82 It inust also analyze "the age of equipment and facilities involved, the process employed, the engineering aspects of the application of various types of control techniques, process changes, [and the] non-water quality environmental impact (includimg energy requirements) ...."83 Similarly complex analytical requirements are not hard to find in agency statutes. ${ }^{84}$

Congress has also enacted statutes specifying broad analytical requirements for all agency rulemaking. The Regulatory Flexibility Act, for example, requires agencies to prepare Regulatory Flexibility Analyses (RFAs) for all significant rules describing the impact of proposed and final rules on sinall businesses and exploring less burdensoine alternatives. ${ }^{85}$ The failure to prepare an RFA is not, however, subject to judicial

82. See American Paper Inst. v. EPA, 660 F.2d 954, $957-59$ (4th Cir. 1981).

83. 33 U.S.C. $\$ 1314($ b)(4)(B) (1988).

84. For example, it is conventional wisdom that statutes that require agencies to regulate "unreasonable" risks require the agencies to balance the costs of risk reduction requirements against the benefits of reduced risk. See, e.g., Federal Insecticide, Fungicide, and Rodenticide Act, 7 U.S.C. $\$ \$ 136(\mathrm{bb}), 136 \mathrm{c}(\mathrm{d})$-(e) (1988). On the other hand, if a statute requires the agency to set a standard on the basis of "feasibility," then a cost-benefit balancing analysis may be inappropriate. See American Textile Mfrs. Inst. v. Donovan, 452 U.S. 490, 510-12 (1981). Sometimes Congress is explicit about imposing a cost-benefit analysis requirement. For example, various amendments to the Consumer Product Safety Act provide that if the Commission proposes a rule, it must publish notice in the Federal Register setting out the costs and benefits of the proposed rule, a discussion of alternatives, and reasons, why suggested voluntary standards were not acceptablc. 15 U.S.C. $\S 2058(a)(5)$, (b)(1), (c) (1988 \& Supp. 1992).

85. 5 U.S.C. $\S \S 601-612$ (1988). The analysis must contain:

(1) a description of the reasons why action by the agency is being considered;

(2) a succinct statement of the objectives of, and legal basis for, the proposed rule;

(3) a description of and, where feasible, an estimate of the number of small entities to which the proposed rule will apply;

(4) a description of the projected reporting, recordkeeping and other compliance requirements of the proposed rule, including an estimate of the classes of small entities which will be subject to the requirement and the type of professional skills necessary for preparation of the report or record;

(5) an identification, to the extent practicable, of all relevant Federal rules which may duplicate, overlap or conflict with the proposed rule.

5 U.S.C. $\S 603$ (b). In addition, the Imitial Regulatory Flexibility Analysis (IRFA) must analyze "significant" alternatives to the agency's proposed action such as:

(1) the establishment of differing compliance or reporting requirements or timetables that take into account the resources available to small entities;

(2) the clarification, consolidation, or simplification of compliance and reporting requirements under the rule for such small entities;

(3) the use of performance rather than design standards; and

(4) an exemption from coverage of the rule, or any part thereof, for such small entities.

5 U.S.C. $\S 603(\mathrm{c})$. The analysis of alternatives, however, need only be undertaken to the extent that it is "[c]onsistent with the stated objectives of applicable statutes." Id. 
review. ${ }^{86}$ The National Environmental Policy Act (NEPA) ${ }^{87}$ requires agencies to prepare an Environmental Impact Statement (EIS) for every proposal for legislation or other major federal action significantly affecting the quality of the human environment. ${ }^{88}$ NEPA's analytical requirements are judicially enforceable, ${ }^{89}$ but the courts lack the power to set aside agency action on the ground that the substance of the action runs counter to NEPA and its underlying policies..$^{90}$

Although the task of assembling the database and technical expertise necessary to meet statutory analytical requirements can be quite burdensome, ${ }^{91}$ analytical requirements are important vehicles for congressional control of administrative discretion. With the demise of the legislative veto, ${ }^{22}$ telling agencies how to think about regulatory problems is one of the few remaining congressional controls on agency output. Congress is therefore not likely to reduce the burdensomeness of rulemaking by granting agencies greater discretion to ignore statutory decisionmaking criteria.

3. Presidentially Imposed Analytical Requirements. From the beginning of the rulemaking revolution in the early 1970s, presidents have attempted to maintain some degree of control over this powerful poicymaking tool. Drawing on the agencies' experience in complying with NEPA, President Nixon established a "Quality of Life" review of regulations promulgated by activist agencies like EPA and OSHA in which proposed regulations were circulated through the executive branch for coinment before being published in the Federal Register. This evolved into an analytical requirement in the Ford and Carter Admimstrations, when agencies were required to prepare Inflation Inpact Stateinents and Regnlatory Analyses. The scope of the required analysis increased draunatically during the Reagan Administration with the promulgation of Executive Order $12,291,{ }^{93}$ which requires agencies to prepare extensive

86. 5 U.S.C. $\S 611(a)$.

87. 42 U.S.C. $\S \S 4321-4370 c$ (1988 \& Supp. 1992)

88. The EIS must describe: (1) the environmental impact of the proposed action; (2) any unavoidable adverse environmental effects; (3) alternatives to the proposed action; (4) the relationship between local short-term uses of environmental resources and the maintenance and enhancement of long-term productivity; and (5) any irreversible and irretrievable commitments of resources. 42 U.S.C. $\S 4332(2)(C)$.

89. See Daniel R. Mandelker, NEPA Law and Litigation § 3:01 (1984).

90. See Strycker's Bay Neighborhood Council, Inc. v. Karlen, 444 U.S. 223, 227 (1980).

91. See Eisner, supra note 53, at 8 (arguing that an "important factor to be considered in analyzing administrative delay, primarily at the federal level, is the increasing number of statutory and executive order requirements that must be met before proposed and final rules can be issued").

92. See INS v. Chadha, 462 U.S. $919,958-59$ (1983).

93. 3 C.F.R. 127 (Comp. 1981), reprinted in 5 U.S.C. $\$ 601$ note (1988). The purpose of the new executive order was "to reduce the burdens of existing and future regulations, increase agency 
Regulatory Impact Analyses (RIAs) ${ }^{94}$ for all major rules. ${ }^{95}$ An agency's failure to prepare an RIA is not judicially reviewable, ${ }^{96}$ but the RIA can play a role in substantive judicial review of the underlying regulation under the "arbitrary and capricious" test.97

The process of preparing an RIA mvolves an information-intense examination of the costs and benefits of the agency's preferred proposal and of numerous alternatives. ${ }^{98}$ For important rulemaking efforts, an agency usually employs numerous consultants and devotes one or more person-years of agency staff to RIA preparation. The average cost of an RIA during the early 1980 s was about $\$ 100,000$, but an RIA sometimes cost more than $\$ 2$ million.99 Although RIA-writing, like EIS-writing, has grown more routine over the years, the prospect of preparing a lengthy RIA still offers a significant incentive to avoid rulemaking. ${ }^{100}$

accountability for regulatory actions, provide for presidential oversight of the regulatory process, minimize duphication and conflict of regulations, and insure well-reasoned regulations . . . Id.

94. The RIA must include:

(1) A description of the potential benefits of the rule, including any beneficial effects that cannot be quantified in monetary terms, and the identification of those likely to receive the benefits;

(2) A description of the potential costs of the rule, including any adverse effects that cannot be quantified in monetary terms, and the identification of those likely to bear the costs; (3) A determination of the potential net benefits of the rule, including an evaluation of effects that cannot be quantified in monetary terms;

(4) A description of alternative approaches that could substantially achieve the same regulatory goal at lower cost, together with an analysis of this potential benefit and costs and a brief explanation of the legal reasons why such alternatives, if proposed, could not be adopted; and

(5) Unless covered by the description required under paragraph (4), . . an explanation of any legal reasons why the rule cannot be based on the requirements [quoted above].

Id. $\S 3(\mathrm{~d})$.

95. A "inajor rule" is any regulation likely to result in:

(1) An annual effect on the economy of $\$ 100$ million or more;

(2) A major increase in costs or prices for consumers, individual industries, Federal, State,

or local government agencies, or geographic regions; or

(3) Siguificant adverse effects on competition, employment, investment, productivity, innovation, or on the ability of United States-based enterprises to compete with foreign-based enterprises in domestic or expert markets.

Id. $\S 1(\mathrm{~b})$. OMB has complete discretion to designate any rule as "major" and to waive the RIA requirement for any major rule. Id. $\S \S 3(\mathrm{~b}), 6(\mathrm{a})(4)$.

96. Id. $\S 9$.

97. See Thomas O. McGarity, Regulatory Analysis and Regulatory Reform, 65 TEx. L. REV. $1243,1317-30$ (1987).

98. Guidehines promulgated by $\mathrm{OMB}$ reiterate the requirement that agencies seriously analyze and consider a variety of alternatives, including alternative levels of stringency, alternative effective dates, alternative methods of assuring compliance, alternative market-oriented regulatory approaches and alternatives beyond their statutory authority. OFFICE OF MANAGEMENT AND Budget, Regulatory Impact Analysis, in Regulatory Program of The UNITEd STATes GovERNMENT app. V (1989).

99. See McGarity, supra note 97, at 1304-07.

100. This is especially true with respect to programs in which the agency cannot consider some of the information in the RIAs in the decisionmaking process. For example, the Supreme Court has held that OSHA may not base its health standards on cost-benefit analysis, and the D.C. Circuit has 
The ability of OMB to waive the requirement, however, reduces its impact on rulemaking efforts designed to reduce the stringency or enhance the flexibility of regulations.

Presidentially imposed analytical responsibilities are not limited to a comprehensive examination of the regulation's costs and benefits: Executive Order 12,630 requires agencies to evaluate the potential that regulations have to effect a "taking" of private property under the Takings Clause of the Fifth Amendment; 101 Executive Order 12,291 requires them to analyze the "trade" impact of regulations; 102 Executive Order 12,612 requires them to analyze the impact of imdividual regulations on "federahsm;"103 and Executive Order 12,606 requires them to consider "family" policymaking criteria in proinulgating regulations. ${ }^{104}$ Judicial review is not available to enforce any of these requirements. ${ }^{105}$ However, these requirements have not proven especially burdensome because they have not been vigorously enforced. Agency officials tend to regard them as "paperwork" requirements that, although having hittle or no relevance to the decisionmaking outcome, bog down the process with additional documents and intra-agency sign-offs. ${ }^{106}$ Although the prospect of preparing takings and federalism analyses has probably never caused an agency to abandon a rulemaking imitiative, such analyses are nevertheless additional extra-statutory hurdles that burden the process and inspire rulemaking avoidance techniques.

\section{Scientific Review Requirements}

Much modern rulemaking is highly technical in nature. Although agencies are supposed to be repositories of expertise, most agencies feel constrained to seek neutral advice from outside scientists. ${ }^{107}$ This function is often fornalized into an additional procedural step in which

held that the Clean Air Act does not allow EPA to consider economic feasibility in promulgating National Prinary Ambient Air Quality Standards. See Ameriean Textile Mfrs. Inst. v. Donovan, 452 U.S. 490, 509 (1981); Lead Indus. Ass'n v. EPA, 647 F.2d 1130, 1148-51 (D.C. Cir. 1980).

101. 3 C.F.R. 554 (1989), reprinted in 5 U.S.C. \& 601 note (1988).

102. See supra notes $93-95$.

103. 3 C.F.R. 252 (Coinp. 1987), reprinted in 5 U.S.C. $\$ 601$ note (1988).

104. 3 C.F.R. 241 (Comp. 1987), reprinted in 5 U.S.C. $\$ 601$ note (1988).

105. Exec. Order No. 12,612, supra note 103, § 8; Exec. Order No. 12,606, supra note 105 , $\S 6$; see Harold H. Bruff, Presidential Management of Agency Rulemaking, 57 GEo. WASH. L. REv. 533, 577-78 (1989).

106. See D. Craig Bell \& Norman K. Johnson, State Water Laws and Federal Water Uses: The History of Conflict, the Prospects for Accommodation, 21 ENVTL. L. 1 (1991); Roger J. Marzulla \& Nancie G. Marzulla, Regulatory Takings in the United States Claims Court: Adjusting the Burdens That in Fairness and Equity Ought to be Borne by Society as a Whole, 40 CATH. U. L. REV. 549, 56669 (1991).

107. See Sheila Jasanoff, The Fifth Branch: Science Advisors as Policymakers 9-12 (1990); Ashford, supra note 58, at 73 (noting that advisory committees have "provided the federal 
outside scientific advisors are asked to subject critical decisionmaking documents and the studies underlying those documents to "peer review."108 Scientific review can enhance the competence of the agencies' technical judgments, ${ }^{109}$ while at the same time deflect criticism from outsiders. ${ }^{110}$ Although a scientific review step is not contemplated by the APA informal rulemaking model, it has become a fixture of technical decisionmaking in EPA, FDA, OSHA, and other scientific rulemaking agencies. Indeed, for a few regulatory programs, scientific review is required by statute. ${ }^{111}$

The Federal Advisory Committee Act ${ }^{112}$ and the Freedom of Information Act ${ }^{113}$ open up the scientific review process to public scrutiny by requiring agencies to charter its advisory committees and make advisory committee meeting minutes available to the public. The cominttees must be balanced and objective, and must consider all sides of the scientific disputes that come before them. ${ }^{114}$ It is not unusual for scientific advisory committees to entertain adversarial debate from affected parties about the scientific adequacy of conclusions and imferences underlying agency position documents. By providing a vehicle for public input into complex science/policy judgments, advisory committees can increase the

government with a means of obtaining expert advice on a wide range of issues at relatively little cost").

108. See National Academy of Sclences, National Research Councll, Decision MAKING FOR REgulating CHEMICALS IN THE ENVIRONMENT 24-25 (1975) (recommending that all agencies that regulate chemicals establish procedures for external scientific review of the technical data base presented to the decisionmaker); Nicholas A. Ashford, The Role of Advisory Committees in Resolving Regulatory Issues Involving Science and Technology: Experience from OSHA and the EPA, in LAW AND SCIENCE IN COLLABORATION, supra note 65, at 165 (examining and recommending improvements for the use of advisory committees for regulating toxic substanees).

109. See Ted Greenwood, KNOWLedge aNd Discretion IN Government Regulation 126-30 (1984) (arguing that the purpose of advisory committees include enhancing the scientific and enginecring competence of regulatory agencies); JASANOFF, supra note 107, at 9-12.

110. GREENWOOD, supra note 109, at 227 ("All agency peer review panels, like the subcommittees of the EPA's Science Advisory Board, can be similarly used by agencies to deflect criticism of their competence."); JASANOFF, supra note 107, at 229.

111. See 42 U.S.C. $\$ 7417$ (1988) (providing for establishment of advisory committees to assist in development and implementation of Clean Air Act); 42 U.S.C. $\S 7409$ (d)(2) (1988) (special scientific advisory committec for reviewing National Ambient Air Quality Standards); 7 U.S.C.A. § 136w(d) (West Supp. 1991) (pesticides scientific advisory panel).

112. 5 U.S.C. app. at 1175-83 (1988). The Federal Advisory Committee Act requires federal agencies that rely upon recommendations of advisory committees to charter those committees. The charter must set out the committee's objectives, duties, number and frequency of meetings, and termimation date. Id. $\S 9$ (c). The agency must prepare minutes for advisory committee meetings, id. $\S 10$ (c), and make those mimutes available to the public, id. $\S 11(\mathrm{a})$, subject to the exemptions in the Freedom of Information Act, id. $\S 10(\mathrm{~b})$.

113. 5 U.S.C. $\$ 552$ (1988).

114. See National Nutritional Foods Ass'n v. Califano, 603 F.2d 327, 334 (2d Cir. 1979); Sidney A. Shapiro, Public Accountability of Advisory Committees, 1 RISK-Iss. HEALTH \& SAFETY 189, 193 (1990). 
likelihood that they will be accepted by the regulated industry and the general public. ${ }^{115}$

Like additional analytical steps, however, scientific review delays the process and increases expenditures. ${ }^{116}$ Agency employees must spend tiine selecting outside reviewers and staffing advisory committee meetings. The busy scientists who serve on these committees must be given generous amounts of time to complete their reviews and incorporate their evaluations into reports to the agency. In addition, the scientists comprising the advisory committees are by nature hesitant to draw conclusions about cause-and-effect relationships relevant to regulatory decisionmaking, and they therefore frequently recommend that the agency refrain from regulating until it has obtained more information on one or more critical points. ${ }^{117}$ Then, after having solicited the outside input, the agency must respond in a rather formal way. ${ }^{118}$ If the agency appears to be ignoring the outside advice, it may encounter dificult pohtical obstacles later in the process, and it will have difficulty recruiting busy scientists to serve on future committees. Thus an agency that

115. See General accounting Office, Delays in EPA's Regulation of Hazardous AIR Pollutants 28 (1983) (Science Advisory Board reviews are conducted "to assure that EPA's documents are scientifically accurate and adequately represent the latest knowledge on health effects."); Ashford, supra note 58, at 73 (advisory committees provide "a means through which public opinion on a particular issue can be made known to responsible officials"); John D. Graham, The Failure of Agency-Forcing: The Regulation of Airborne Carcinogens Under Section 112 of the Clean Air Act, 1985 DukE L.J. 100, 122.

116. See Graham, supra note 115, at 118 (EPA's Science Advisory Board takes threc to six months to review hazardous air pollutant health assessment documents).

Advisory committees can also be "stacked" to ensure scientific support for a preordained pohicy decision. See JASANOFF, supra note 107, at 87-88 (detailing how the Reagan Administration attempted to stack EPA's Science Advisory Board); Ashford, supra note 58, at 76-77; Shapiro, supra note 114, at 192 (an administrator can "stack" a committce "with scientists whose past actions indicate that they will generally resolve science/policy questions in accordance with the administrator's policy preferences . ..."). This aspect of advisory committees, however, goes beyond the ossification problem, and it will not be discussed further in this Article.

117. Ted Greenwood concludes that:

Academic research scientists and engineers are, by virtue of their training and professional norms, inclined to refrain from reaching conclusions within their professional specialty until adequate evidence is available. However, because adequate evidence is often not available in regulatory decision-making, .... an advisory committce of acadenic researchers is likely to act as an inhibitor of regulation when an agency must make a positive finding of hazard before regulating or can only require controls that are feasible.

GREENwOOD, supra note 109, at 195. Greenwood recounts two occasions when the science advisory committees returned EPA risk assessments for further work, even though EPA's carcinogen assessment group concluded that the available information supported a policy of regulating the substances as carcinogens. Id.

118. See Graham, supra note 115, at 121 (noting that although the Clean Air Act only requires EPA to consult with appropriate advisory committees, "it is the EPA's policy to delay listing and regulatory deeisions until SAB approval of the health assessment document has been obtained"). 
desires to slow down the rulemaking process can usually depend on scientific review to provide an excuse for delay. ${ }^{119}$ At the same time, an agency that wants to act expeditiously can reject an advisory committee's requests for additional data only if it is willing to go through the timeconsuming exercise of explaining its reasons for doing so. ${ }^{120}$

\section{Substantive Review Requirements}

Perhaps the most effective control on the exercise of administration is to subject final decisions to evaluation by a reviewing institution capable of vetoing the mitiative or remanding it to the agency for further work. All three branches perform this review function to some extent, and all three rather jealously guard their review roles. Since the nature of their review is very different, the branches will be examined separately.

1. Judicial Review. The APA provides that informal rules may be set aside if they are "arbitrary or capricious," represent an "abuse of discretion," or are "otherwise not in accordance with law."121 In its first attempt to provide guidance on the ineaning of this test, the Suprente Court said that a reviewing court must "consider whether the decision was based on a consideration of the relevant factors and whether there has been a clear error of judgment." It cautioned that "[a]lthough this mquiry into the facts is to be searching and careful, the ultimate standard of review is a narrow one."122 Front this cryptic guidance, the lower courts during the latter half of the 1970s fashioned the "hard look" scope of review doctrine, under which a reviewing court was obliged to examine carefully the administrative record and the agency's explanation, to determine whether the agency apphed the correct analytical methodology, apphed the right criteria, considered the relevant factors, chose from anong the available range of regulatory options, relied upon appropriate pohicies, and pointed to adequate support in the record for material empirical conclusions. ${ }^{123}$

119. Ashford, supra note 108, at 168.

120. See Administrative Conference of the United States, Recommendation No. 82-5, Federal Regulation of Cancer-Causing Chemicals, 1 C.F.R. $§ 305.82-5$, at 119 (1992); see also Shapiro, supra note 114, at 190 ("If an adninistrator takes actions inconsistent with a committee's recommendations, and the administrator fails to explain adequately the departure, [political and judicial] overseers are more likely to modify or reverse the deeision.").

121. 5 U.S.C. $\$ 706(2)(A)(1988)$.

122. Citizens to Preserve Overton Park v. Volpe, 401 U.S. 402, 416 (1971).

123. The phrase "hard look" was coined by Judge Levanthal. See Harold Levanthal, Environmental Decisionmaking and the Role of the Courts, 122 U. PA. L. REv. 509, 514 (1974) ("The court does not make the ultimate deeision, but it insists that the official or agency take a 'hard look' at all relevant factors."); see also JoHn E. Bonine \& THOMAs O. MCGARITY, THE LAw OF ENvironMENTAL PRotection 142 (2d ed. 1991) (describing the evolution of the "hard look" doctrine). In 
The Supreme Court in 1983 captured a decade's worth of doctrinal evolution in the lower courts when it reformulated the hard look doctrine to hold an agency rule arbitrary and capricious if:

the agency has relied on factors which Congress has not intended it to consider, entirely failed to consider an important aspect of the problem, offered an explanation for its decision that runs counter to the evidence before the agency, or is so implausible that it could not be ascribed to a difference in view or the product of agency expertise. ${ }^{124}$

The practical application of the hard look doctrine has varied widely from circuit to circuit and from case to case within circuits. ${ }^{125}$ During the 1970 s the overall judicial trend was toward a more activist substantive judicial review in which the courts defined the issues less in terms of agency expertise and more in terms of pohtical value judgments. ${ }^{126}$ Consequently, several important agency rulemaking initiatives during the 1970 s were styınied by judicial remands. ${ }^{127}$

Judge Wald's view, the role of the reviewing courts under the "hard look" doctrine is "to make sure that agency 'expertise' does not disguise agency refusal to deal with agomizing questions or with cogent opposition to its intended direction." Patricia M. Wald, Judicial Review of Complex Administrative Agency Decisions, 462 AnNals AM. ACAD. Pol. \& Soc. ScI. 72, 77 (1982).

124. Motor Vehicle Mfrs Ass'n v. State Farm Mut. Auto Ins. Co., 463 U.S. 29, 43 (1983).

125. See Alfred C. Aman, Jr., Administrative Law in a Global Era: Progress, Deregulatory Change and the Rise of the Administrative Presidency, 73 CORNELI L. REv. 1101, 1163 (1988) (suggesting that the stringency of judicial review may depend upon whether the agency is engaged in "economic" regulation (e.g., setting rates for rail carriers) or "social" regulation (e.g., setting occupational health standards for toxic chemieals)); Ronald M. Levin, Scope-of-Review Doctrine Restated: An Administrative Law Section Report, 38 ADMIN. L. REV. 239, 240 (1986); Rodgers, supra note 75, at 301 ("Judges . . a accumulate boilerplate responses, one in defense of a hands-off disposition, another for explaining a decision to lay the hands on. Any conscientious search for guidance on whether to intervene or defer is likely to come up short.").

126. See Aman, supre note 125, at 1149 (suggesting that the courts took a constitutional-like judicial review approach toward the health, safety, and environmental statutes); Stephen Breyer, Judicial Review of Questions of Law and Policy, 38 ADMIN. L. REv. 363, 384 (1986) (arguing that the courts have been increasingly willing to overturn agency policy decisions); Peter L. Strauss, One Hundred Fifty Cases per Year: Some Implications of the Supreme Court's Limited Resources for Judicial Review of Agency Action, 87 CoLUM. L. REv. 1093, 1129 (1987) (reading the State Farm test quoted supra in the text accompanying note 124 as "a strong endorseinent of quite aggressive judicial review of agency action ....").

Judge Wald has suggested an even more aggressive "nurseinaid" inetaphor for the role of the courts in overseeing administrative ruleinaking. Patricia M. Wald, Making "Informed" Decisions on the District of Columbia Circuit, 50 GEo. WASH. L. REv. 135, 138 (1982); see infra text aecompanying notes 292-94.

127. See infra text accoinpanying notes 131-69. Soine observers contend further that the courts have been manipulating doctrines of substantive judicial review to achieve particular substantive results. Levy and Glicksinan, for example, suggest that the Supreme Court in its environmental law opinions has pursued a consistently pro-development policy. Richard E. Levy \& Robert L. Glicksman, Judicial Activism and Restraint in the Supreme Court's Environmental Law Decisions, 42 VAND. L. Rev. 343, 422 (1989). Similarly, Professor Pierce suggests that the decisions of the D.C. Circuit in the 1980 s can only be explained by the policy predilections of the individual judges and whether the majority of the judges on any given case was appointed by a Republican or Deinocratic 
Many observers have concluded that substantive judicial review has had a profound impact on the way agencies make rules. ${ }^{128}$ Fully aware of the consequences of a judicial remand, the agencies are constantly "looking over their shoulders" at the reviewing courts in preparing supporting documents, in writmg preambles, in responding to public comments, and in assembling the rulemaking "record." Because they can never know what issues dissatisfied hitigants will raise on appeal, they must attempt to prepare responses to all contentions that may prove credible to an appellate court, no matter how ridiculous they may appear to agency staff. ${ }^{129}$ Having gone to the considerable effort of a successful rulemaking, the agencies are understandably reluctant to change their rules to adapt to experience with the rules or changed circumstances. ${ }^{130}$

It is not hard to find examples of judicial overreaching. In an exhaustive study of rulemaking in the NHTSA, Professors Mashaw and Harfst found that stringent judicial review is largely responsible for that agency's virtual abandonment of rulemaking in favor of case-by-case recalls. Pointing out that NHTSA lost six of the twelve rulemaking cases decided on the merits, ${ }^{131}$ the authors concluded:

With no rehiable method for discerning what issues raised by participants might be treated as miportant by reviewing courts, or what changes im a proposal would be considered sufficiently substantial to require another round of notice and comment, NHTSA could hardly be faulted for taking a very cautious approach to rejecting either manufacturers' substantive arguments or their requests for further proceedings to explore new or modified issues. ${ }^{132}$

president. Pierce, supra note 11, at 300 (" $[T]$ he fate of a major agency policy decision reviewed by the D.C. Circuit will vary with the composition of the panel that reviews the agency action.").

128. Judge Stephen Breyer believes that the principles embodied in the hard look doctrine have far greater substantive impact than one might at first realize. A remand of an important agency rule (several years in the making) for more thorough consideration may well mean several years of additional proceedings, with mounting costs, and the threat of further judicial review leading to abandonment or modification of the initial project irrespective of the merits.

Breyer, supra note 126 , at 383. Breyer suggests that the courts often are aware of the significant impact of their decision when they remand a rulemaking initiative to an agency. See id.; see also Mashaw \& Harfst, supra note 37, at 262-63; Richard J. Pierce, Jr., The Role of the Judiciary in Implementing an Agency Theory of Government, 64 N.Y.U. L. REV. 1239, 1263-64 (1989); Pierce, supra note 11, at 300-01; Strauss, supra note 126, at 1131 (observing that the hard look doctrine has "a tendency to produce excessive agency effort on any given administrative action, to the general prejudice of an agency's level of accomplishment").

129. See Graham, supra note 115, at 118 (noting that in the context of regulating hazardous air contaminants, "the EPA has attempted to protect itself from judicial reversal by including progressively more sophisticated and comprehensive analyses in its health assessment documentation").

130. See Breyer, supra note 126, at 391 ("The stricter the review and the more clearly and convincingly the agency must explain the need for change, the more reluctant the agency will bc to change the status quo.")

131. Mashaw \& Harfst, supra note 37, at 273.

132. Id. at 286 . 
Two years after its first debilitating defeat on the minor (and, in the ininds of agency officials, preposterous) ground that its dummies had been inadequately tested, the agency explained the ossification of its own rulemaking process to a congressional committee "with the simple answer that any faster action would simply invite reversal on judicial review."133

Professor Pierce has impressively demonstrated that the D.C. Circuit has had a profound impact on rulemaking in the Federal Energy Regulatory Commission (FERC). That court systematically and, Pierce has argued, imconsistently, reversed every FERC attempt to implement a fresh policy of natural gas regulation based upon antitrust policies. In Maryland People's Council v. FERC, ${ }^{134}$ the court held that FERC's policy violated the Natural Gas Act, and suggested that FERC adopt a policy requiring equal access to pipeline transportation for gas sold by third parties. On remand, the agency caine up with such a policy and explained why it believed the policy to be consistent witl the Natural Gas Act and the court's prior holding; the court, however, remanded once again. ${ }^{135}$ Finally, in American Gas Association v. FERC,136 the court held the entire equal access policy invalid because, the court reasoned, it was part of a "package" that was "tainted" by FERC"s failure to give "adequate" consideration to an alternative method of allocating transaction costs that FERC had rejected. Pierce has concluded that these cases demonstrate a "remarkable [judicial] instinct for the capillary" that may be premised upon a failure to recognize that "time does not stop while agencies and courts engage in further deliberations" and that "agencies have severely constrained resources." 137

Judicial review also had a debilitatimg effect on the rulemaking efforts of the Federal Trade Commission (FTC) in the 1970s. During the 1960s, when the FTC's authority to promulgate rules of general applicability was unclear, the agency promulgated rules, and tliose that were challenged survived judicial review under the "arbitrary and capricious"

133. Id. at 284 .

134. 761 F.2d 768 (D.C. Cir. 1985).

135. Associated Gas Distributors v. FERC, 824 F.2d 981 (D.C. Cir. 1987), cert. denied, 485 U.S. 1006 (1988). According to Professor Pierce:

FERC apparently assumed that, by addressing the transition cost allocation issue identified by the $A G D$ court, choosing one of the options suggested by that court, and giving reasons for its choice, it was complying with the court's mandate. That assumption, logical as it might sound, proved unjustified.

Pierce, supra note 3, at 24.

136. 888 F.2d 136 (D.C. Cir. 1989).

137. Pierce, supra note 3, at 24 . 
test. ${ }^{138}$ After Congress in 1974 clarified the FTC's power to enact rules of general apphicability (pursuant to hybrid rulemaking procedures), FTC initiated several important rulemaking initiatives. The very first judicial review of one of these newer rules resulted in a humiliating remand to the agency. In Katharine Gibbs School v. FTC, ${ }^{139}$ the petitioners challenged FTC's rule pertaining to proprietary vocational and home study schools. Instead of defining particular acts or practices of the industry that were unfair or deceptive, the FTC had specified particular requirements relating to refunds, disclosure, and cooling-off periods, and concluded that a violation of any of those provisions was itself unfair and deceptive. ${ }^{140}$ In addition to holding that the statute did not allow FTC to proceed in this fashion, ${ }^{141}$ the court held that several provisions did not pass the "substantial evidence" test apphicable to FTC rules. ${ }^{142}$ By contrast, during roughly the same period, the agency succeeded regularly in judicial review of its cease-and-desist orders aimed at unfair advertisimg. ${ }^{143}$

One of the most frequent agency hitigants, the Environmental Protection Agency (EPA), has also been on the receiving end of unduly stringent judicial review. EPA's initial attempts to promulgate standards for industrial dischargers of pollutants reflecting the "best practicable teclinology currently available" during the middle 1970s, the heyday of the "hard look" doctrine, were hamstrung by frequent judicial remands. In CPC International, Inc. v. Train, ${ }^{144}$ for example, the court reviewed

138. See, e.g., National Petroleum Refiners Ass'n v. FTC, 482 F.2d 672 (D.C. Cir. 1973), cert. denied, 415 U.S. 951 (1974). Not all of FTC's early rules were so controversial as to precipitate judicial review. During the 1960 s, FTC routinely addressed such profoundly significant topics as "deceptive advertising as to sizes of viewable pictures shown by television receiving sets," "discriminatory practices in men's and boys" tailored clothing industry," and "failure to disclose the lethal effects of inhaling quick-freeze aerosol spray products used for frosting cocktail glasses." 16 C.F.R. pts. 410, 412, 417 (1991).

139. 612 F.2d 658 (2d Cir. 1979).

140. Id. at 662 .

141. Id.

142. For example, the agency rules required that proprietary schools refund tuition on a pro rata basis. The court criticized this approach, stressing that "[r]efunds on such a pro rata basis do not take into account those costs that are fixed at the time of enrollment, such as salaries for teachers and staff, classroom and boarding facilities, administration overhead, books, and supplies." Id. at 663. The court continued:

The rationale of the Rule is said to be the "[creation of] structural disincentives to indiscriminate enrollment", which, translated into less dainty language, means "the creation of structural incentives for discriminate enrollnient." ... The Cornmission argues that this foray into the field of edueation is a "reasoned exercise of its legislative judgment" in an area "plainly within its expertise, i.e, unfair selling practices." ... We disagree.

Id. (brackets in original).

143. See, e.g., Warner-Lambert Co. v. FTC, 562 F.2d 749 (D.C. Cir. 1977), cert. denied, 935 U.S. 950 (1978).

144. 515 F.2d 1032 (8th Cir. 1975). 
EPA's new source performance standard for the "Corn Wet Milling Subcategory" of the "Grain Mills Point Source Category." According to the statute, EPA was supposed to base the standard on the "best available demonstrated control technology." 145 However, EPA based its standard on the less strimgent "best practicable technology currently available"146 plus "deep bed filtration." EPA predicted that the addition of deep bed filtration could reduce pollutants to ouly twenty pounds of biochemical oxygen demand (BOD) and ten pounds of total suspended solids (TSS) per thousand standard bushels (MSBu) of corn that was milled. ${ }^{147}$

EPA virtually conceded that no existing corn wet milling plant had installed deep bed filtration, but it argued that the technology was a relatively simple one that had been successfully implemented in other industries with similar effluent streams. The industry petitioners argued that the corn wet milling industry was uniquely susceptible to "shockloads," and that its effluent contained such high concentrations of suspended solids that it would clog up the deep bed filtration devices. Deferring not at all to EPA's expertise, the court concluded that "[g]iven the unique nature of the corn wet milling effluent, and the apparent relevance of its uniqueness to the efficacy of deep bed filtration, the EPA cannot rely upon a presumption of transferability of that technology."148 The court

145. 33 U.S.C. $\$ 1316(a)(1)$ (1988) (applying to new sources).

146. Id. $\S 1311(\mathrm{~b})(1)(\mathrm{A})(\mathrm{i})$. The statute required that "best practicable technology currently available" be installed in existing sources by a statutory deadline. The agency determined that "recirculated cooling water, aerated equalization, activated sludge, and good housekeeping practices," was the "best practicable technology" and that it would result in effuent containing on average 50 pounds of biochemical oxygen demand (BOD) and 50 pounds of total suspended solids (TSS) per thousand standard bushels (MSBu) of corn that was milled. CPC Int'l, 515 F.2d at 1045. "Best available deınonstrated control technology" for new sources was intended to be more stringent.

147. According to the court, the "correctness" of EPA's conclusion that the new source performance standards could be inet

hinge[d] on the validity of four intermediate conclusions: (1) that the 1977 technology is

"deinonstrated" and "available" for new plants; (2) that the 1977 technology will be sufficient to reinove all but 50 pounds each of $\mathrm{BOD}_{5}$ and TSS per MSBu; (3) that the incremental deep bed filter technology is "deinonstrated" and "available" for new plants; and (4) that the increinental technology will be sufficient to remove an additional 30 pounds of $\mathrm{BOD}_{s}$ and 40 pounds of TSS per MSBu.

515 F.2d at 1046. The court found support in the record for EPA's first two conclusions, id., but found that the second two were not reasonable, id. at 1049.

148. Id. at 1048-49 (footnotes omitted). The court in a footnote noted that EPA had elsewhere declared that "if the biological facility is subject to frequent upsets, filtration will be inuch inore difficult." Id. at 1048 n.33 (citing earlier EPA report). This observation, however, was entirely beside the point, because EPA acknowledged from the outset that any violations of the uniforn technology-based standards caused by excusable "upsets" would not subjeet the source to penalties, and the agency later required an "upset" defense to be written into every permit for point sources subject to the Clean Water Act. See American Petroleuin Inst. v. EPA, 661 F.2d 340 (5th Cir. 1981) (upholding EPA's regulations for the oil and gas extraction industry on the ground that EPA's National Pollutant Discharge Elimination Systen (NPDES) permit regulations provide for upset defenses). 
also noted that "even if the EPA could rely on a presumption of transferability, the record is barren of any evidence as to what the performance of deep bed filters has been outside the industry." 149 The court remanded the standard to EPA with instructions to respond to the remand within 120 days. As the inatter was being remanded to EPA anyway, the court took the occasion to instruct the agency to do a better job in assessing the costs compliance with the standard. In particular, the court noted that the long pendency of the proceedings (including judicial review) had rendered the agency's cost data obsolete. The court instructed the agency to use more recent cost data in its reconsideration of the standard on remand. ${ }^{150}$

EPA dutifully responded to the remand with more information and analysis to support the same standard, based on the same technology. The court, however, was unimpressed with the agency's performance. ${ }^{151}$ While EPA had adequately supported its twenty pounds per MSBu standard for BOD, ${ }^{152}$ it had still failed to provide adequate record support for the ten pounds per MSBu standard for TSS. After an extensive analysis of EPA's explanation and data, the court rejected the agency's conclusion that the efficacy of deep bed filtration had been deinonstrated in the regulatee CPC International's own plant. ${ }^{153}$ The court rejected much of EPA's TSS data from other industries on the ground that it was expressed in milligrams per liter, rather than in pounds per MSBu, thus making coinparisons impossible to a person unfamiliar with the appropriate conversion factors. The court even rejected the conclusion of an independent expert and acknowledged authority on filtration of wastewaters, because it was "replete with qualifications." 154 After pondering what to do following the agency's failed second attempt to promulgate a

149. 515 F.2d at 1049 n.36.

150. Id. at 1050-51.

151. CPC Int'1, Inc. v. Train, 540 F.2d 1329 (8th Cir. 1976), cert. denied, 430 U.S. 966 (1977).

The court criticized the agency for assembling a record that was opaque to judicial eyes:

Much of the data in the record is presented without careful collation, evaluation and simplification. Much of the statistical information is quantified in units of measurement other than those used in the proposed standards, pounds per thousands of bushels, thus making it difficult for us to determine whether the data supports the EPA's conclusion. Expert opinion is frequently uusupported and little, if any, effort is made to make scientific testiinony understandable.

Id. at 1332.

152. Id. at 1338.

153. Id. at 1338-39. Although the data from the recently completed plant showed that it consistently inet the BOD standard, the data hikewise demonstrated that the plant consistently failed to meet the TSS standard. The court viewed this as strong evidence that even the addition of deep bed filtration could not assure that the industry could meet the TSS new source limitations. Id. at 1339. In light of this direet evidence in the corn wet milling industry, the court found the evidence of better deep bed filtration performance in other industries unpersuasive. Id.

154. Id. at 1340 . 
supportable standard, the court found that although the existing record could not support a standard of ten pounds of TSS per MSBu, it did support a standard of twenty-five pounds of TSS per MSBu, which was still much less than the regulatee CPC thought was possible. The court therefore gave EPA a choice: It could either return to the drawing board to atteinpt to support its ten pounds TSS per MSBu standard, or it could accept the judicially suggested coinpromise. ${ }^{155}$ It should come as no surprise to discover that the new source performance standard for the corn wet milling industry is now twenty-five pounds of TSS per MSBu. ${ }^{156}$

The CPC International opinion, and the fact that nearly all of EPA's first round of technology based standards resulted in remands on one or more technical issues, had a profound impact on the agency. Rather than respond to the reinands, the agency in all but one case decided to give up, and it failed to proinulgate national "best practicable technology" standards for most of the pollutants in most of the industries for which it had suffered a judicial remand.

The efforts of the Consuiner Product Safety Commission (CPSC) to promulgate health and safety rules to protect consumers have likewise been stymied by aggressive reviewing courts. In Gulf South Insulation v. Consumer Product Safety Commission, ${ }^{157}$ the court overturned the CPSC's ban on the use of urea-formaldehyde foam insulation (UFFI) in residences and schools on the highly dubious ground that the data available to the agency was too uncertain to support their use in a risk assessment model that yielded point estiniates. ${ }^{158}$ After testing 1,164 hoines containing UFFI for ambient levels of formaldehyde and arranging for further tests of commercially available UFFI products in simulated wall panels, CPSC applied the "Global 79" risk assessment model to predict that the increased risk of cancer to a person living in a UFFI home for mine years would range from 0 to 51 in 1,000,000.159 Criticizing the agency for not randomly selecting the 1,164 test homes, the court found that the model's predictions were tainted by its focus on "coinplaimt" residences, as opposed to "average" formaldehyde-treated homes. ${ }^{160}$ However, the court did not explain why the agency was not allowed to rely upon a reasonable worst-case scenario in estimating the risk to an individual hiving in a UFFI home. Most important, the court failed to

155. Id.

156. 40 C.F.R. $\S 406.15$ (1991).

157. 701 F.2d 1137 (5th Cir. 1983).

158. Id. at $1145-47$.

159. Id. at $1141-42$.

160. Id. at 1145. Of the 1,164 test homes, 827 were homes in which the occupants had complained about UFFI-related health problems, and 337 were non-complaint homes. Id. at 1144 \& n.10. 
establish how it was qualified to render the science/policy judgment that the data available to the agency was "inadequate to serve as a data base" for the inodel.

The court also disputed the validity of CPSC's reliance on aninal studies to estimate human cancer risks. Although several epidemiological studies had discovered no increase in cancer rates among workers exposed to formaldehyde, in a laboratory study in which rats were exposed to inoderately high levels of formaldehyde, 103 out of 240 contracted nasal cancer. ${ }^{161}$ Despite language in numerous appellate court opinions validating the ability of regulatory agencies to rely upon aninal studies to regulate chemicals that might pose cancer risks to humans, ${ }^{162}$ the Gulf South court opined that "in a study as sinall as this one the margm of error is inherently large."163 Without citation, the court stated its finding that "had 20 fewer rats, or 20 inore, developed carcmomas, the risk predicted by Global 79 would be altered drastically." 164 The court concluded: "To make precise estimates, precise data are required."165 Nowhere in the agency's statute, however, is there any hint of a requirement that the agency make "precise" risk estimates. The agency did not rely upon the precision of the Global 79 risk assessment inodel; it simply plugged some admittedly imprecise data on possible huinan exposure and the results of a sinall but well-conducted aninal study imto a inodel to gain a rough estiniate of the maguitude of risks faced by persons im homes containing UFFI. The court sinply ignored the agency's expertise and policy judgments (and the expertise and policy judgments of several other federal agencies that have routinely relied upon risk estimates based upon animal studies) in its search for perfection in the administrative record.

161. Id. at 1146 .

162. See, e.g., Environmental Defense Fund, Inc. v. EPA, 598 F.2d 62, 88 (D.C. Cir. 1978) (placing heavy burden on administrator seeking to permit continued use of chemical known to produce cancer in animals, but allowing discretion when evidence is less clear); Hercules, Inc. v. EPA, 598 F.2d 91, 115 (D.C. Cir. 1978) (noting that the "[c]hoice among scientific test data is precisely the type of judgment that innst be made by EPA'); Environmental Defense Fund, Inc. v. EPA, 548 F.2d 998, 1005-10 (D.C. Cir. 1976), cert. denied, 431 U.S. 925 (1977); Environmental Defense Fund, Inc. v. EPA, 510 F.2d 1292, 1299 (D.C. Cir. 1975); Society of Plastics Indus., Inc. v. OSHA, 509 F.2d 1301, 1308 (2d Cir.), cert. denied, 421 U.S. 992 (1975); Synthetic Organic Chem. Mfrs. Ass'n v. Brennan, 503 F.2d 1155, 1157 (3d Cir. 1974); Environmental Defense Fund, Inc. v. Ruckelshaus, 439 F.2d 584 (D.C. Cir. 1971) (deferring to EPA's judgment in analyzing test of DDT on test animals).

163. 701 F.2d at 1146.

164. Id.

165. Id. 
Although Gulf South has been much criticized by legal scholars and scientists alike, ${ }^{166} \mathrm{CPSC}$ could not ignore it. The agency did not respond to the court's remand, and in the eight years since the Fifth Circuit's decision, CPSC has not attempted to regulate a single additional toxic product. ${ }^{167}$ While the agency's inactivity was no doubt influenced by other external factors, includimg a President who was determined to abolish the agency ${ }^{168}$ and congressionally imposed restrictions on its rulemaking authority, ${ }^{169}$ the Gulf South case might easily have persuaded the agency of the impossibility in the Fifth Circuit of assembling a record capable of supporting its regulation of carcinogens im consumer products.

The predictable result of stringent "hard look" judicial review of complex rulemaking is ossification. Because the agencies perceive that the reviewing courts are inconsistent in the degree to which they are deferential, they are constrained to prepare for the worst-case scenario on judicial review. This can be extremely resource-intensive and time-consuming. ${ }^{170}$ Moreover, since the criteria for substantive judicial review

166. See Nicholas A. Ashford et al., A Hard Look at Federal Regulation of Formaldehyde: A Departure from Reasoned Decisionmaking, 7 HARV. ENVTL. L. REV. 297, 368 (1983)("[W]e find the Fifth Circuit's analysis to be unpersuasive in its evaluation of CPSC's cancer risk assessment for formaldehyde."); Devra L. Davis, The "Shotgun Wedding" of Science and Law: Risk Assessment and Judicial Review, 10 Colum. J. ENVTL. L. 67, 85 (1985) ("The decision stands simply as a remarkable judicial probe of an agency's record on a narrow question."); Howard Latin, Good Science, Bad Regulation, and Toxic Risk Assessment, 5 YAlE J. oN REg. 89, 131 (1988) ("The court's opinion reflects ... a fundamental misunderstanding of the limited evidence on which most risk assessments of carcinogens are based."); Richard A. Merrill, The Legal System's Response to Scientific Uncertainty: The Role of Judicial Review, 4 FundamENTAL \& APpLIEd TOXicology S418, S425 (1984) ("The opinion's close scrutiny of an exercise that is fraught with uncertainty, but yet promises improvement in regulation of health hazards, is disconcerting."). But see Cass R. Sunstein, In Defense of the Hard Look: Judicial Activism and Administrative Law, 7 HARV. J.L. \& PUB. PoL'Y 51, 53 (1984) (praising the Fifth Circuit for relying on the hard look doctrine to "ensure that regulatory controls are well-founded" and to promote "private ordering"). Sunstein does not explain why "private ordering," which he suggests is a historic goal of judicial review, is a loftier goal than consumer protection.

167. Indeed, the only regulation of any substance promulgated by CPSC since the Gulf South decision in 1983 is a ban on hazardous lawn darts. 16 C.F.R. $§ \S 1306.1-5$ (1991) (promulgated Nov. 18, 1988; effective Dec. 19, 1988).

168. See, eg., Merrill Brown, Reagan Wants to Ax Product Safety Agency, WASH. Post, May 10, 1981, at A4.

169. See supra Part $\mathrm{II}(\mathrm{B})(2)$; infra Part $\mathrm{II}(\mathrm{D})(2)$.

170. A comprehensive study of EPA's decisionmaking process for promulgating National Ambient Air Quality Standards concluded in 1984 that:

Litigation and the prospect of court review are the dominant factors that infiuence the NAAQS process throughout all its phases. Fcar of litigation and how the courts might judge the process tends to delay decisions. Actual litigation, however, tends to force decisions to be made. The Agency shows the highest respect and response to the courts over any other influence. Every phase of the process is desigued to withstand and pass judicial review. Much of the process's attempt to do the "right thing" is motivated by strong desire that the courts be able to find "no errors" in the way the Agency conducts its business. It 
are the same for repealing old rules as for promulgating new rules, ${ }^{171}$ the agencies are equally chary of revisiting old rules, even in the name of flexibility. ${ }^{172}$

There are some tentative indications that the appellate courts are beginning to apply the hard look doctrine somewhat more deferentially in recent years. In Sierra Club v. Costle, ${ }^{173}$ the D.C. Circuit resisted vigorous attempts from both industries and environmental groups to overturn EPA's technology-based new source performance standard for steam electric power plants under the Clean Air Act. In a group of cases involving vigorous challenges to EPA's complex regulations implementing the statutory ban on land disposal of untreated hazardous wastes and settimg treatment standards for such wastes, the D.C. Circuit sustained EPA's actions, even though EPA was forced by statutory deadhines to write the regulations within a very short time frame. ${ }^{174}$ More recently, the D.C. Circuit rejected all challenges to EPA's amended National Ambient Air Quality Standards for Particulate Matter, the subject of a lengthy and contentious rulemaking. ${ }^{175}$

After the Second Circuit remanded FTC's Proprietary Vocational Schools rule in 1979176 and the D.C. Circuit partially remanded the

is the cautious attention that is given to producing "no errors" that tends to slow the process down.

Michael A. Berry, A Method for Examining Policy Inplementation: A Study of Decisioninaking for the National Ambient Air Quality Standards, 1964-1984, at 221 (1984). The study was undertaken as Mr. Berry's dissertation at the University of North Carolina at Chapel Hill. After Mr. Berry became the Deputy Director of the Environmental Criteria and Assessinent Office of EPA's Office of Air Quality Planning and Standards, the dissertation was published as an EPA document.

171. Motor Vehicle Mfrs. Ass'n v. State Farm Mut. Auto. Ins. Co., 463 U.S. 29, 41 (1983).

172. See Eisner, supra note 53, at 8 (agencies' "concern over 'strict judicial review of agency policy decisions is a strong conservative pressure in favor of the status quo' ") (citation omitted); Mashaw \& Harfst, supra note 37, at 294 ("[Stringent judicial review] is pernicious because it gives enormous leverage to the status quo, whether the statns quo is no rule ... or the continuance of a rule ....").

173. 657 F.2d 298 (D.C. Cir. 1981).

174. American Petroleun Inst. v. EPA, 906 F.2d 729 (D.C. Cir. 1990) (rejecting industry challenges to several aspects of the "First-Third Rule," but remanding for reconsideration of environmental group's contentions regarding waste stream K061); Hazardous Waste Treatment Council v. EPA, 886 F.2d 355 (D.C. Cir. 1989) (rejecting substantive challenges to "solvents and dioxins" rule, but remanding for fuller explanation of why EPA used a technology-based approach), cert. denied, 111 S. Ct. 139 (1990); Mobil Oil Corp. v. EPA, 871 F.2d 149 (D.C. Cir. 1989) (upholding regulations implementing "national capacity variance" regulations pronulgated in conjunction with waste treatinent standards for "First-Third" wastes); Chemical Waste Managennent, Inc. v. EPA, 869 F.2d 1526 (D.C. Cir. 1989) (rejecting challenge to leachate portion of "First-Third" rule).

175. Natural Resources Defense Council, Inc. v. EPA, 902 F.2d 962 (D.C. Cir. 1990); see also MCGARITY, supra note 27, at 45-61 (describing the particulates rulemaking).

176. Katharine Gibbs Sch. v. FTC, 612 F.2d 658 (2d Cir. 1979). 
agency's Opthalmic Practices rule in $1980,{ }^{177}$ the courts have not overturned an FTC rule. The courts found the used car rule, ${ }^{178}$ the credit practices rule, ${ }^{179}$ the funeral industry practices rule, ${ }^{180}$ and changes in the required inethodology for testing tar and nicotine levels of cigarettes $^{181}$ to be supported by substantial evidence and not to be arbitrary and capricious.

Even the Fifth Circuit, which developed a reputation during the 1970s and early 1980s as an inhospitable forum for agencies intent upon regulatimg private conduct, adopted a more deferential approach to agency regulations in Chemical Manufacturers Ass'n v. EPA. ${ }^{182}$ The court, with only one minor exception, upheld in their entirety EPA's technology-based effluent limitations for the organic chemicals, plastics, and synthetic fibers mdustries. ${ }^{183}$ EPA had assembled an enormous technical base for the categorical standards to support its effluent limitations representing "best practicable technology," "best available technology" for toxic substances, "best available demonstrated technology" for new sources, and pretreatinent standards for indirect dischargers. Although the chemical manufacturers and their trade association launched the usual blunderbuss attack on the technical bases for the regulations, the court rejected every argument with a noticeable bow of deference to the agency. The only issue on which the court remanded was

177. American Optometric Ass'n v. FTC, 626 F.2d 896 (D.C. Cir. 1980).

178. Consumers Union, Inc. v. FTC, 801 F.2d 417 (D.C. Cir. 1986). The attack on the used car rule came from a consumers' group that argued that the rule was too lax because it omitted a provision requiring disclosure of known defects. Rather than an indication of mcreased judicial deference to administrative action, this case could be read merely to indicate increased judicial deference to deregulatory action.

179. American Fim. Servs. Ass'n v. FTC, 767 F.2d 957 (D.C. Cir. 1985), cert. denied, 475 U.S. 1011 (1986). In this substantial challenge to a controversial FTC rule, the court npheld the agency in every regard. The court noted that the rule "was painstakingly considered and siguificantly modified in response to the extensive comments and recommendations received during this long rulemaking proceeding." Id. at 963 . Quoting D.C. Circuit precedent, the court held that the "arbitrary and capricious" test " "forbids the court's substituting its judgment for that of the agency, and requires affirmance if a rational basis exists for the agency's decision.' " Id. at 985 (quoting Ethyl Corp. v. EPA, 541 F.2d 1, 34 (D.C. Cir.) (citations omitted), cert denied, 426 U.S. 941 (1976)).

180. Harry \& Bryant Co. v. FTC, 726 F.2d 993 (4th Cir.), cert. denied, 469 U.S. 820 (1984).

181. Brown \& Williainson Tobacco Corp. v. FTC, 710 F.2d 1165 (6th Cir. 1983), cert. denied, 465 U.S. 1100 (1984). The courts did, however, remand two agency rules during the same period on the ground that the agency lacked the statutory authority to promulgate these rules. Califormia State Board of Optometry v. FTC, 910 F.2d 976 (D.C. Cir. 1990); Public Citizen v. FTC, 869 F.2d 1541 (D.C. Cir. 1989).

182. 870 F.2d 177 (5th Cir.), clarified in part, 885 F.2d 253 (5th Cir. 1989), cert. denied, 495 U.S. 910 (1990).

183. The briefs submitted to the court of appeals totaled more than 3,000 pages. A joint appendix of more than 9,000 pages was distilled from an administrative record of more than 600,000 pages. 870 F.2d at 184 . The court's initial jointly authored opinion (laden with almost 400 footnotes) consumed over 90 pages in the Federal Reporter. 
EPA's conclusion that recycling teclinology had not been adequately demonstrated for purposes of the new source performance standard, contrariwise to an environmental group's showing that more than thirty plants had already successfully installed recycling teclinology. ${ }^{184}$

There are, however, some equally strong indications of a trend in the opposite direction. For example, in Corrosion Proof Fittings $v$. $E P A,{ }^{185}$ EPA attempted for the first time to regulate a toxic substance under section 6(a) of the Toxic Substance Control Act. ${ }^{186}$ That statute provides that when EPA determines that there is a reasonable basis to conclude that exposure to a toxic substance presents or will present an unreasonable risk of injury to health or tlie environment, the agency must apply the least burdensome of eight listed regulatory options, one of which is a requirement prohibiting the use of the substances in commerce. EPA carefully analyzed the costs and benefits of banning asbestos and, in a soinewhat inore cursory fashion, examined the costs and benefits of other alternatives, including the "do nothing" option.

The court held that EPA did not adequately consider less burdensome options short of doing nothing. The court noted that "[w]liile the EPA inay have shown that a world with a complete ban of asbestos might be preferable to one in which there is only the current amount of regulation, the EPA has failed to show that there is not soine intermediate state of regulation that would be superior to both the currently-regulated and the completely-banned world." 187 The court explained how EPA could make this showing:

Upon an initial showing of product danger, the proper course for the EPA to follow is to consider each regulatory option, beginning with the least burdensome, and the costs and benefits of regulations under each option. The EPA cannot sinply skip several rungs, as it did in this case, for in doing so, it may skip a less-burdensome alteruative mandated by TSCA. 188

The court went on to prescribe $\mathrm{m}$ detail the nature of the cost-benefit analysis that the agency was required to employ. For example, the

184. Id. at 264. On the other hand, the Fifth Circuit recently remanded OSHA's standard for grain elevators, finding that the agency had not adequately justified its cost projections underlying its finding that the standard was economically feasible for the industry. National Grain \& Feed Ass'n v. OSHA, 866 F.2d 717, 738-40 (5th Cir. 1989). The court also found, at a union's behest, that the record did not support the agency's decision to limit the standard to limited areas within a given facility. Id. at 735. After OSHA responded to the remand with adequate cost figures, the court allowed the standard to go into effect. National Grain \& Feed Ass'n v. OSHA, 903 F.2d 308 (5th Cir. 1990).

185. 947 F.2d 1201 (5th Cir. 1991).

186. 15 U.S.C. $\$ 2605(\mathrm{a})$.

187. 947 F.2d at 1217 .

188. Id. 
court plunged into the exceedingly treacherous waters of health benefits analysis and, without even a nod to the extensive economic and philosophical hiterature on the propriety of discounting future health benefits to present value, ${ }^{189}$ lield that EPA was obliged to make the atteinpt. Althougli TSCA offers not the slightest predicate for sucli a requirement, the court referred the agency to an article in The Economist tliat, according to the court, explained the use of discount rates for non-monetary goods. ${ }^{190}$ The court also criticized the agency for projecting benefits too far out into the future, for relying too lieavily upon the concept of population exposure, and for its evaluation of the availability of substitutes for asbestos. ${ }^{191}$

The Fifth Circuit opmion in Corrosion Proof Fittings is so lacking in deference to the agency's exercise of expertise and policy judgment, and so full of attempts to impose on the agency the judges' own views of the proper role of regulation in society, that it is virtually indistinguisliable from the documents that OMB prepares in connection witl its oversiglit of EPA rulemaking. Faced with the daunting prospect of ineeting the court's information-gatliering and analytical requirements, EPA may be forgiven if it elects to channel its limited resources in other directions. Unless the statute is ainended to send a clear message to the reviewing courts that something less than a thorougligoing analysis of every listed option will do, EPA's first section 6(a) rulennaking will undoubtedly be its last.

The appellate courts can find strong support for a more deferential approach in the second lialf of the Supreine Court's Cotton Dust decision, whicli uplield OSHA's reasoning with respect to the feasibility of the cotton dust regulation. 192 The industry claimed that OSHA had underestiinated coinpliance costs and liad incorrectly concluded that the standard would not threaten the economic viability of the cotton industry. Applying the "substantial evidence" test required by the Occupational Healtli and Safety Act, the court examined two studies in the record that OSHA claimed supported its conclusions. One study was prepared by an OSHA contractor, the Research Triangle Institute (RTI), and the otlier, tlie Hocutt-Tliomas study, was prepared for the industry by two contractors.

OSHA rejected its own contractor RTI's cost estmiate of $\$ 1.1$ billion for tliree reasons. First, it discounted the RTI estimiate by thirty percent, as the estimiate was based on the erroneous assumption that engineering controls would be used for all equipment in the textile inills,

\footnotetext{
189. See MCGARITY, supra note 27.

190. 947 F.2d at 1218.

191. Id. at 1218-19.

192. American Textile Mfrs. Inst. v. Donovan, 452 U.S. 490 (1981).
} 
including those processing pure synthetic fibers. ${ }^{193}$ Second, the agency concluded that RTI's estimate failed to take into account that some operations had already comphed with the promulgated standard. Third, OSHA found the RTI data to be out-of-date. Because the industry study was based on more recent data, OSHA adopted its estimate of $\$ 543$ million, which the agency beheved was still on the high side. ${ }^{194}$ The industry argued that OSHA could not rationally rely upon the HocuttThomas study, as that study presumed a somewhat less stringent standard than the one OSHA actually promulgated. 195 OSHA responded that it could have done a better job with the financial analysis had the mdustry been more forthcoming with its cost data. ${ }^{196}$

The Supreme Court declined to overturn the court of appeal's determination that OSHA's conclusions were supported by "substantial evidence" in the rulemaking record: "While a cost estimate based on the standard actually promulgated surely would be preferable, we decline to hold as a matter of law that its absence under the circumstances required the Court of Appeals to find that OSHA's determination was unsupported by substantial evidence."197 If this is an application of the "hard look" doctrine, it is a dramatically softer version of that doctrine than the version apphed by the appellate courts in Corrosion Proof Fittings, Gulf South and CPC International.

It is still too soon to conclude that the appellate courts have in fact adopted a less intrusive attitude about substantive judicial review. Any decrease im the frequency of remands from new rulemaking initiatives could be explained by the fact that the agencies themselves were much

193. The RTI study itself recognized that excluding equipment that did not process cotton fibers could reduce its estimates by as much as $30 \%$. Id. at 524 .

194. The agency concluded that even this estimate was high for four reasons. First, the HocuttThounas study included costs of achieving the existing standard, whereas OSHA concluded that compliance with the existing standard was unore widespread, and that soine mills had in fact achieved the new standard. Second, the Hocutt-Thomas study did not make any allowance for the trend toward replacement of existing production machines with newer and more productive equip. ment that would not require retrofitting in order to meet the OSHA standard. Third, OSHA concluded that the Hocutt-Thomas study failed to take into account development of new technologies during the four-year period in which the industry had to comply. Finally, OSHA thought that the Hocutt-Thoinas study, like the RTI study, might have improperly imcluded control costs for unachines that processed only synthetic fibers. Id. at 525-26.

195. The industry stressed that "only by the most remarkable coincidence would the ainount of [the Hocutt-Thomas] overestimate be equal to the additional costs required to attain the far more stringent himits of the Standard OSHA actually adopted." Id. at 527.

196. Many of the companies surveyed in the Hocutt-Thomas study had withheld data from the agency on grounds of confidentiality. When he testified, Hocutt adinitted: "Practically all of this information that I have is confidential and I couldn't reveal any of the sources. You can only take my word for the figures. I can't substantiate it in any manner." Id. at 528 n.51.

197. Id. at 528-29. 
less aggressive about regulating private conduct during the 1980s. ${ }^{198}$ For example, the particulates standard discussed above did not differ greatly from the preexisting standard, and the hazardous waste standards were not regarded as sufficiently stringent by environmental groups. EPA's recent successes may only stand for the proposition that it is relatively less difficult for EPA to justify a standard that does very little to change the status quo. Similarly, simce FTC has promulgated only two fullfledged rules and two substantial amendments to an existimg rule during the last decade, ${ }^{199}$ it is unclear whether the agency's recently improved batting average is attributable to better perforinance on the agency's part, increasing deference in the reviewing courts, or a few lucky trips to the plate. It is no doubt easier to support a rule that does not press the industry very hard. This explanation is consistent with the increased number of "bureaucracy forcing" cases during the 1980 s in whicl the courts were not especially deferential toward agency refusals to regnlate. ${ }^{200}$

198. Levy and Glicksman suggest that the apparent imcrease in judicial deference experiences during the late 1980 s may in fact be explained by a coincidence between the implementation of prodevelopment policies in the agencies and a preference for those policies in the reviewing courts:

More recently, the Supreme Court appears to have ... [emphasized] judicial restraint im its environmental decisions. Proponents of judicial restraint assnme this shift has limited the Court's power to implement its own policy preferences. Under this presumed limitation the Court's decisions simply reflect the environmental policies of other governinental institutions. These recent Supreme Court decisions, however, reflect a trend seemingly at odds with congressional policy, reaching pro-development results far more often than pro-environment results. While this shift may reflect the exercise of judicial restraint toward governmental institutions other than Congress that have pursued a development-oriented policy, the shift also may be the result of the Court's own pro-development policy. This latter possibility draws into question the traditional assumption that judicial restraint prevents the Court from implementimg its own policy choices.

Levy \& Glicksman, supra note 127 , at 346 . This explanation would suggest that the courts might be less deferential toward a reinvigorated effort on the part of regulatory agencies to promulgate new rules that are not comfortably supported by the information in the rulemaking records.

199. See FTC Care Labeling of Textile Wearing Apparel Rule, 16 C.F.R. $\$ 423$ (1991); FTC Retail Food Store Advertising and Marketing Practices Rule, id. § 424; FTC Credit Practices Rule, id. § 444; FTC Funeral Industry Practices Rule, id. § 453.

200. See Environmental Defense Fund v. Ruckelshaus, 3 Envtl. L. Rep. (Envtl. L. Inst.) 20,173 (D.D.C. 1973) (requiring EPA to promulgate final hazardous einissions standards for asbestos, beryllium, and mercury); Natural Resources Defense Council, Inc. v. Train, 510 F.2d 692 (D.C. Cir. 1974) (requiring EPA to publish water effuent limitations guidelines); Natural Resources Defense Council, Inc. v. Train, 411 F. Supp. 864 (S.D.N.Y. 1976) (requiring EPA to list lead as a criteria pollutant in its air quality standards); Natural Resources Defense Council, Inc. v. Costle, 14 Env't Rep. Cas. (BNA) 1858 (S.D.N.Y. 1980) (requiring EPA to promulgate regulations under Toxic Substances Control Act for industry testing of chemicals); Environmental Defense Fund, Inc. v. Gorsuch, 12 Envtl. L. Rep. (Envtl. L. Inst.) 20,376 (D.D.C. 1982) (requiring EPA to propose revisions to National Contingency Plan for hazardous substance spills); Farm Worker Justice Fund, Inc. v. Brock, 811 F.2d 613 (D.C. Cir.), vacated as moot, 817 F.2d 890 (D.C. Cir. 1987) (requiring OSHA to promulgate farm worker safety standards); Natural Resources Defense Council, Inc. v. EPA, 707 F. Supp. 3 (D.D.C. 1989) (refusing to extend prior judicially inposed deadline since statutory deadline had expired). See generally BoNINE \& MCGARITY, supra note 123, at 787-97. 
Professors Mashaw and Harfst perceptively observe that the blame cannot be laid entirely at the doorstep of the judiciary. The courts have operated in the context of a legal culture in which the legitimacy of governmental intervention into private affairs is still in doubt. For example, Congress created the CPSC in 1972 with the ainbitious goals of protecting the public from injury due to unsafe products, assisting consumers in evaluating the safety of products, developing uinform standards for product safety, and proinoting research and investigation into the causes of product-related injuries and deaths. ${ }^{201}$ After CPSC undertook several ambitious rulemaking initiatives during the late 1970s, Congress clipped its wings in 1981. The 1981 amendments limited CPSC's standard-setting options so that it could write only "performance," labelling, and warning standards, and not requirements governing the contents, composition, design, construction, finish, or packaging of products. ${ }^{202}$ The 1981 amendments also required the Commission to rely on voluntary standards, rather than promulgating legal standards, whenever compliance with voluntary standards would eliminate or adequately reduce the risk of injury froin the products, and it is likely that the voluntary standards would result in substantial coinphance. ${ }^{203}$

It is inpossible to draw definitive conclusions about the extent to which judicial review under the hard look doctrine has contributed to rulemaking ossification. The agencies probably had good reason to devote considerable attention to the details of the rulemaking record and agency explanations during the late 1970 s and early 1980s. Whether less effort is warranted in the 1990s is not an easily resolved question. The causation question, in any event, depends as inuch upon perceptions as reahty. As long as the relevant agency decisioninakers believe that they must expend additional resources in anticipation of overly intrusive judicial review, they will be reluctant to undertake new rulemaking initiatives, to experiment with inore flexible regulatory techniques, and to revisit old ruleinaking efforts.

2. Congressional Review. Although Congress maintains a keen interest in the rulemaking process, it has not successfully implemented a regularized institutional role for itself in reviewing individual rulemaking

201. 15 U.S.C. $\S \S 2051(b), 2053$ (1988).

202. Compare 15 U.S.C. § 2056(a)(1) (1988) with 15 U.S.C. § 2056(a)(1) (1972).

203. 15 U.S.C. $\$ 2056(b)$ (1988). Further amendments in 1990 provided that the voluntary standards must already be in existence and approved by the organization that developed them before the rulemaking proceeding is terminated. Id. § 2058(b)(2) (Supp. 1992). The 1990 Amendments also added a provision giving the Commission power to devise procedures to monitor compliance with the voluntary standards. Id. § 2056(b)(2) (Supp. 1992). 
efforts. ${ }^{204}$ The legislative veto, a crude but effective review mechanism, was initially quite successful in hamstringing the FTC,205 but it was held unconstitutional im the Chadha case. ${ }^{206}$ The potency of ad hoc review by interested committees through agency oversight and appropriations hearings, however, should not be understated. Although agencies are not much concerned about congressional review when they assemble the detailed technical support for rules, they must be constantly aware of probable congressional reaction to major policy decisions made during individual rulemakings. Even after Chadha, Congress can undo rulemaking initiatives, either directly by statute or indirectly by limitations written into agency appropriations. ${ }^{207}$ Congress can make the agencies very aware of the fact that Congress is looking over the agencies' shoulders by requiring that proposed rules or other explanatory documents be routinely submitted to relevant congressional committees. ${ }^{208}$

Perceived negative congressional reaction can effectively inhibit change through the rulemaking process. For example, since Congress amended CPSC's statute in 1981, that agency has written only three rules, two of which were mitiated prior to the amendments. ${ }^{209}$ In contrast, between the creation of the agency in 1972 and the 1981

204. See Harold H. Bruff, Legislative Formality, Administrative Rationality, 63 TEx. L. REv. 207, 207 (1984) (arguing that the Supreme Court has "confined important aspects of congressional supervision of the agencies to the Constitution's formal procedure for enacting statutes").

205. FTC's rules for used cars were vetoed by the legislature. See Consumers Union of the United States v. FTC, 691 F.2d 575 (D.C. Cir. 1982). The Supreme Court later declared the used car legislative veto unconstitutional. United States Senate v. FTC, 463 U.S. 1216 (1983) (affirming decision of the D.C. Court of Appeals).

206. INS v. Chadha, 462 U.S. 919 (1983). Pierce argues that the legislative veto, $m$ any event, merely vested greater coutrol over ageucy policymaking in a few legislators on the committees with jurisdiction over the relevant agencies. Richard J. Pierce, $\mathrm{J}_{\mathrm{r} .,}$, The Role of Constitutional and Political Theory in Administrative Law, 64 TEX. L. REv. 469, 483-84 (1985).

207. See, e.g., 15 U.S.C. $\$ 57$ a(i) (1988) ("The Commission shall not have any authority to promulgate any rule in the children's advertising proceeding pending on May 28, 1980, or in any substantially similar proceeding on the basis of a determination by the Commission that such advertising coustitutes an unfair act or practice in or affecting commerce.").

208. For example, the 1981 amendments to the Cousumer Product Safety Act provide that the agency's reasons for failing to adopt "voluntary" standards subnitted by the regulated industry during the rulenlaking process must be subnitted to the Senate Committee on Comnerce, Science and Transportation and the House Committee on Energy and Coinmerce. 15 U.S.C. § 2058(c) (1988).

209. The three rules that CPSC has issued siuce 1981 are the safety standard for omuidirectional citizens band base statiou antennae, 16 C.F.R. pt. 1204 (1992) (promulgated Aug. 19, 1982); the standard for coal and wood burning appliances-notification of performance and technical data, 16 C.F.R. pt. 1406 (1992) (promulgated May 16, 1983); and the ban of hazardous lawn darts, 16 C.F.R. pt. 1306 (1992) (promulgated Nov. 18, 1988). The first two of these were initiated prior to the 1981 amendmeuts. See 46 Fed. Reg. 41,081 (1981) (notice of proposed rulemaking for omnidirectional antennae); 45 Fed. Reg. 76,018 (1980) (notice of proposed rulemaking for coal and wood burning applianees). 
amendments, CPSC had written six rules. ${ }^{210}$ Once regulated entities have made expenditures in rehance on existing rules, they can make a good case to sympathetic members of Congress that the agency should leave well enough alone. Nevertheless, the extent to which the threat of negative congressional reaction burdens the rulemaking process, as opposed to affecting agency priorities, is difficult to gauge. ${ }^{211}$

3. Presidential Review. While the 1980 s witnessed a diminishment in direct congressional review of agency rulemnaking and a possible decline in the stringency of substantive judicial review of rulemaking, direct presidential control dramatically increased.212 This increase in presidential supervision resulted in part from a determined insistence by President Reagan to "regain control" over what was beheved to be a runaway bureaucracy, the criticism of which had been a inajor theme in his election and reelection campaigns. ${ }^{213}$ But increased presidential supervision also represented an attempt by the President and the staff of the Office of Management and Budget to redirect the substantive policies of the agencies away from interventiomist "command and control" solutions to societal problems, and toward less intrusive market-oriented approaches. $^{214}$ Because less intrusive policies could often be impleinented by merely doing nothing, ossification, to some extent, became a tool for

210. CPSC Safety Standard for Architectural Glazing Materials, 16 C.F.R. $§ 1201$ (1992); CPSC Safety Standard for Matchbooks, id. § 1202; CPSC Safety Standard for Walk-Behind Power Lawn Mowers, id. § 1205; CPSC Safety Standard for Swimming Pool Slides, id. § 1207; CPSC Interim Safety Standard for Cellulose Insulation, id. § 1209; CPSC Safety Standard Requiring Oxygen Depletion Safety Shutoff Systems (ODS) for Universal Gas-Fired Space Heaters, $i d$. § 1212.

211. See McCubbins et al., supra note 6, at 435 ("[A]gencies may not regard threats of punishment as credible, especially if the threats are froin Congress.").

212. See Aman, supra note 125, at 1105-06, 1198-99, 1222, 1236-37; Bruff, supra note 105, at 552 (observing that during the 1980s OMB became increasingly political "with a sharp upsurge from nine to twenty-five Schedule C political appointees in the first Reagan term alone"); William F. West \& Joseph Cooper, Legislative Influence v. Presidential Dominance: Competing Models of Bureaucratic Control, 104 PoL. SCI. Q. 581, 581 (1990) (arguing that "the emergent inodel of political oversight, which advocates centralized presidential control over agency policy inaking while prescribing a passive role for Congress, iguores key goals of our political system as well as important external influenees and internal constraints that shape institutional behavior").

213. See, e.g., Merrill Brown, Reagan "Reforms" Would Tighten Congressional Grip on Agencies, WASH. Post, Oct. 12, 1980, at A4. See generally Bruff, supra note 105, at 539 (referring to "an enduring tension between presidential supervision of execution and congressional supremacy over legislation").

214. See George C. Eads \& Michael Fix, Relief or Reform? Reagan's Regulatory Agenda 88, 101-05 (1984); SUSAN J. TOlChin \& MarTin Tolchin, Dismantling America: THE RUSH TO DEREGULATE 267 (1983) (noting that "the regulatory reform packages introduced by the last two Presidents have led to the same objective: to get away from the command and control form of regulation, and return to a system of looser standards that will reduce costs and increase efficiency"); Christopher C. DeMuth \& Douglas H. Ginsberg, White House Review of Agency Rulemaking, 99 HARV. L. REv. 1075, $1075-76$ (1984). 
advancing a particular substantive policy. Obstructing and delaying activist rulemaking initiatives while at the same time treating deregulatory initiatives to a mere passing glance, ${ }^{215}$ fostered a noninterventionist, inarket-oriented approach to societal probleins.

Executive Order 12,291 requires agencies to submit all rules to OMB for review for fidehty to the Executive Order's analytical requirements. Agencies cannot consider a new rulenraking imitiative or send proposed or final rules to the Federal Register without OMB approval. 216 Although tied to an analytical exercise, the OMB review process became the primary vehicle for presidential micro-managenient of the ruleinaking process during the 1980s. In the summer of 1990, President Bush assigned the responsibility for overseeing the Executive Order 12,291 review process to a newly created "Council on Conıpetitiveness," chaired by Vice President Quayle and coniposed of the Secretaries of Commerce and the Treasury, the Attorney General, the Director of OMB, the Chairman of the Colmcil of Economic Advisors, and the President's Chief of Staff. ${ }^{217}$ Executive Order 12,498, signed by President Reagan after his second election, estabhished an additional vehicle for macromanagenrent of the rulemaking process by creating a "Regulatory Agenda" of all executive branch rulenraking initiatives: Every agency must submit to OMB for approval all regulatory imitiatives it plans to inplement within the coming year. ${ }^{218}$ Iten1s that OMB does not include on the agenda cannot be the subject of a notice of proposed rulenaking, absent unusual circuinstances. Under these extensive delegations of presidential authority, OMB's review of agency rulenraking has proved far more intrusive during the 1980s and early 1990 s than either judicial or congressional review. At every stage of the rnlemaking process, the agencies are very conscious of OMB's watchful presence.

The sharp debate in the legal and pohcy literature about the legitimacy of OMB review of agency rulemaking need only be briefly recapitulated here. ${ }^{219}$ The fact that the President is at the "apex of governinent"

215. See Bruff, supra note 105, at 563 n.163 (noting the Reagan Administration's use of categorical waivers of $\mathrm{OMB}$ review for deregulatory actions).

216. Exec. Order No. 12,291, supra note $93, \S \S 3,6$.

217. Memorandum from the Vice President to Secretary Martin, Department of Labor (Mar. 15, 1991) [hereinafter Martin Memorandum]; see also Action by Quayle Council Signals Revival of Deregulatory Presence, BNA WASH. INSIDER, Dec. 21, 1990, available in LEXIS, BNA Library, BNAWI File. The Council on Competitiveness has a full-time executive director (currently a former businessman from Indiana) and four full-time staffers. The source of funding for this new organization is unclear.

218. Exec. Order No. 12,498, supra note $62, \S 1$ (a).

219. Articles on OMB review abound. E.g., Lloyd N. Cutler \& David R. Johnson, Regulation and the Political Process, 84 YALE L.J. 1395, 1410 n.50 (1975); DeMuth \& Ginsburg, supra note 214; C. Boyden Gray, Presidential Involvement in Informal Rulemaking, 56 TUL. L. REv. 863 
gives OMB and the Council on Competitiveness a "unique perspective" on pohicymaking in the federal bureaucracy. ${ }^{220}$ Substantive presidential review can help ensure consistency in pohicy implementation across the executive branch and thereby help prevent agencies from acting at crosspurposes with one another. 221 Similarly, subjecting executive branch rulemaking to review by the only two officials elected from a national constituency (the President and Vice President) helps foster public accountability.222 Some proponents of OMB review argue that it can loosen up bureaucratic rigidity because the President and his advisors are closer than the bureaucrats to the real world where problems arise.223 Proponents also argue that $\mathrm{OMB}$ review can reduce the number of unjustifiable and unworkable rules, as well as the number of rules that fail to reflect a proper balance between narrow agency goals and the broader public interest. ${ }^{224}$

(1982); Philip J. Harter, Executive Oversight of Rulemaking: The President Is No Stranger, 36 AM. U. L. REv. 557, 564-69 (1987); Oliver A. Houck, President $X$ and the New (Approved) Decisionmaking, 36 AM. U. L. REv. 535 (1987); Louis L. Jaffe, Invective and Investigation in Administrative Law, 52 HARv. L. REv. 1201, 1238-39 (1939); Alan B. Morrison, OMB Interference with Agency Rulemaking: The Wrong Way to Write a Regulation, 99 HARv. L. Rev. 1059 (1986); Erik D. Olson, The Quiet Shift of Power: Office of Management \& Budget Supervision of Environmental Protection Agency Rulemaking Under Executive Order 12,291, 4 VA. J. NAT. Resources L. 1 (1984); Morton Rosenberg, Presidential Control of Agency Rulemaking: An Analysis of Constitutional Issues That May Be Raised By Executive Order 12,291, 23 ARIz. L. Rev. 1199, 1199-1200 (1981); Peter M. Shane, Presidential Regulatory Oversight and the Separation of Powers: The Constitutionality of Executive Order No. 12,291, 23 ARIz. L. Rev. 1235 (1981); Peter L. Strauss \& Cass R. Sunstein, The Role of the President and OMB in Informal Rulemaking, 38 ADMIN. L. REV. 181, 206-07 (1986); Peter L. Strauss, The Place of Agencies in Government: Separation of Powers and the Fourth Branch, 84 CoLUM. L. REv. 573, $640-67$ (1984); Paul R. Verkuil, Jawboning Administrative Agencies: Ex Parte Contacts by the White House, 80 Colum. L. REv. 943, 981 (1980); see also MCGARITY, supra note 27, at 292-300.

220. See Bruff, supra note 105, at 553; Peter L. Strauss, Considering Political Alternatives to "Hard Look" Review, 1989 DukE L.J. 538, 548. As a spokesperson for the Competitiveness Council somewhat arrogantly argued: "[I]t is better that the vice president and the top representatives of the president are the ones who resolve admimistration policy on sensitive matters, rather than some green eye-shade type in the bowels of the bureaucracy." Quayle Competitiveness Council Called Secretive, Meddlesome by OMB Watch Report, BNA WASH. INSIDER, Sept. 9, 1991, available in LEXIS, BNA Library, BNAWI File (statement of Mr. David Beckwith, Vice President Quayle's press secretary).

221. See Cutler \& Johnson, supra note 219, at 1406; Gray, supra note 219, at 863; Slrane, supra note 219 , at 1245 .

222. See Myers v. United States, 272 U.S. 52, 123 (1926); Bruff, supra note 105, at 554, 561-62; Cutler \& Johnson, supra note 219, at 1405-06, 1411; Harter, supra note 219, at 567-69; Strauss \& Sunstein, supra note 202, at 190; cf. Pierce, supra note 206, at 520-21 (noting that "Congress is the most politically accountable institution," but that the "President is unuch more politically accountable than the judiciary").

223. See Cutler \& Johnson, supra note 219, at 1410-11; Strauss, supra note 220, at 548-49.

224. See Bruff, supra note 105, at 555; Cutler \& Jolnson, supra note 219, at 1405-06; DeMuth \& Ginsburg, supra note 214, at 1080-82. 
None of these arguments, however, is overwhelmingly persuasive. It is true that $\mathrm{OMB}$ is in a good position to coordinate activities that involve more than one agency; however, there is not much evidence that OMB officials do in fact devote inuch of their attention to that role.225 The accountability argument loses considerable force when it is understood that the President and Vice President are in fact ordinarily too busy to play a direct role in regulatory policymaking and therefore delegate the oversight function to unelected bureaucrats in OMB and the Council on Competitiveness. 226 Indeed, to the extent that cominunications between the regulatory agencies and OMB or the Council on Competitiveness take place behind closed doors, the President cannot be held accountable for his decisions or those of the executive office staff. Next, bureaucratic rigidity, while usually an unattractive feature of regulatory programs, can also be a necessary constraint against corruption of the regulatory process for financial or political gain. Fimally, the argument that OMB review begets better rules depends a great deal upon the observer's point of view. For example, the review program under President Reagan was in large part devoted to the highly normative goal of "regulatory relief." 227 Thus only if "better" means "less stringent" does OMB review produce better rules. Unabaslred pursuit of regulatory rehef is debatable not only as a national policy goal, but also because it relegates Congress to a backseat role in domestic pohicyinaking. One could just as persuasively argue that OMB should not be allowed to amend congressionally enacted statutes through the closed regulatory review process.

OMB review also has several affirmative disadvantages. First, rulemaking initiatives that are low on OMB's agenda languish, even if they are high priorities for the agencies. ${ }^{228}$ During the 1980s, OMB critics wonld refer to the review process as a "black hole" into which regulations disappeared, never to be seen again.229 Although acknowledging that it has occasionally dragged its feet in reviewing agency regulations, ${ }^{230} \mathrm{OMB}$ 's typical response is that the average time for OMB review

225. See Bruff, supra note 105, at 590 (pointing ont the lack of strong evidence that OMB during the Reagan Administration attempted to identify and rectify inconsistency in the implementation of policy).

226. See West \& Cooper, supra note 212, at 596-97 (challenging the notion that the President is accountable to the electorate for regulatory decisionmaking and arguing that "executive review will naturally be influenced, not necessarily by broad majoritarian interests, but by groups that are powerful, inteuse, and close to the president").

227. EADS \& FIX, supra note 214, at 104-05; Demuth \& Ginsberg, supra note 214, at 1080; see Gray, supra note 219 , at 863 .

228. See MCGARITY, supra note 27, at 271-91.

229. See, e.g., Tolchin \& Tolchin, supra note 214 , at 74 .

230. See Judith Havemann, OMB's Pledge: No More Foot-Dragging; Darmon Concedes Agency Procrastinated in Reviewing Regulations, WASH. Post, July 4, 1989, at A21. 
of a rule is less than sixty days. ${ }^{231}$ However, these averages include a very large number of unimportant and uncontroversial rules that go through the agencies unimpeded. ${ }^{232}$ Significant ruleniaking initiatives that matter a great deal to the agencies, regulated industries, and beneficiary groups can take years to clear OMB review. For example, EPA's extremely important "corrective action" rule governing the extent to which hazardous waste disposal facilities must clean up existing contamination struck a raw nerve in $\mathrm{OMB}$, and the two agencies wrangled over the substance of the rule for almost two years. ${ }^{233}$ When OMB digs in its heels, agencies frequently withdraw proposed rules, rather than debate regulatory policy with OMB interninably. ${ }^{234} \mathrm{OMB}$ has even attempted to stifle agency initiatives entirely by refusing to place them on the regulatory agenda. ${ }^{235}$

Second, OMB review can dramatically change the outcome of the rulemaking process because it strives mightily to minimize the inipact of regulations on the regulated industries. In the process, OMB staffers are not reluctant to supplant congressional policy judgments with their own

231. See Executtve Office of the President, Regulatory Program of the United STATES GOVERNMENT, APRIL 1, 1990-MARCH 31, 1991, at 647 (1990) [hereinafter REgUlATORY PROGRAM] (21-day average time for review of all rules and 40-day average time for review of all major rules between 1981 and 1989); DeMuth \& Ginsburg, supra note 214, at 1088 ("Eighty percent of the regulations reviewed by OMB are cleared without change, and almost all of these spend fewer than ten days at OMB.").

232. The 21- and 40-day averages cited above are based on averages across all rules reviewed by OMB from 1981-1989. In 1989 alone, OMB reviewed 2,220 rules. REgulATORY PROGRAM, supra note 231, at 636. Thus some very large delays for a few important rules can average with cursory reviews of thousands of unimportant rules to yield a misleading average for all rules.

233. Corrective Action Rule Dispute Continues as OMB Regulatory Office Faces Threat, 21 Env't Rep. (BNA) 334 (June 15, 1990).

234. For example, EPA in 1989 withdrew rulemaking mitiatives for air emissions from hazardous waste disposal facilities and for biotechnology. See REgulatory Program, supra note 231, at 642.

235. For example, OSHA's very first regulatory agenda included a safety standard for the oil and gas industry. OMB tried to keep the standard off the agenda, arguing that a separate regulation for the oil and gas industry was not warranted and that OSHA should, instead, devote its resources to health standards. Ouly after Labor Secretary William Brock's office intervened was OSHA allowed to repropose the standard on its agenda. See OSHA Expected to Repropose Oil-Gas Rule Despite Reported Opposition from $O M B$ and Industry, Daily Rep. Execs. (BNA) No. 134, at A3 (July 12, 1985).

OSHA did not fare as well when it announced in 1985 that, in light of the 1984 Bhopal tragedy, it was adopting recommendations for management systems to ensure overall plant safety and that it was considering requiring inandatory self-audits of safety devices in chemical plants. After OMB refused to place the initiative on the Regulatory Agenda, it was placed on the back burner until July, 1990, when the catastrophic explosion at an ARCO Chemical plant in Channelview, Texas killed 17 workers. See 55 Fed. Reg. 29,150 (1990); see also Hearings on the Adequacy of OSHA Protections for Chemical Workers (pt. 2): Hearings Before the Subcomm. on Employment and Housing of the House Comm. on Government Operations, 101st Cong., 2d Sess. 27-32 (1990) (testiunony of Mr. Lynn Williams, United Steelworkers of America). 
policy preferences. ${ }^{236}$ OMB can use the threat of delay to extract substantive concessions froin the agencies, ${ }^{237}$ which, in order to ineet OMB objections, covertly allow their decisions to be guided by considerations tliat Congress has precluded or to reflect extrastatutory policies. ${ }^{238}$

Finally, OMB staffers not infrequently attempt to substitute their judgments in suclı highly technical areas as science, engineering, and economics for that of the agencies to which Congress has delegated decisionmaking responsibility. ${ }^{239}$ Most agency officials are quite resentful of the lack of respect that $\mathrm{OMB}$ economists have for agency expertise, and they jealously guard agency prerogatives against OMB usurpation of decision1naking authority. ${ }^{240}$ For exainple, OMB once ordered EPA to consider options for stack height requirements (to protect against acid rain) ${ }^{241}$ that an appellate court liad already declared unlawful in the very ruleinaking proceeding at issue. In another case, OMB ordered OSHA to delete a requirement for a short-terın exposure limit for etlyylene oxide the might before a court-ordered deadline for publishing the standard in the Federal Register. ${ }^{242}$

Because OMB officials feel free to substitute their views for the policy judgments of the agencies to which Congress has delegated regulatory authority, OMB review interjects substantial uncertainties into the rulemaking process. There is uncertainty at the very outset, as agency officials cannot know wliether internally generated solutions to problems that arise in the early development of a rule will withstand OMB review. The absence of a clear vehicle for appealing substantive disputes with OMB to a higher level in the Administration only adds to the uncertainties. ${ }^{243}$ The agencies cannot engage in time-saving compromises with regulatees or public interest groups for fear of being overturned by OMB.

236. See Houck, supra note 219 , at $540-45$; Olson, supra note 219 , at $49-52$; Strauss \& Sunstein, supra note 219 , at 190.

237. Bruff, supra note 105 , at 565-68.

238. See Jonathan Lash, A Season of Spoils: A Reagan Administration's AtTack on THE ENVIRONMENT (1984); TolchIN \& TolchIN, supra note 214; Morrison, supra note 219, at 1067; Olson, supra note 219, at 74-75.

239. See MCGARITY, supra note 27, at 281; OMB Doubts over Lead's Health Risks May Threaten Future EPA Regs, Staff Say, INSIDE EPA, Feb. 22, 1991, at 1 (reporting a fundamental dispute between OMB and EPA over EPA's estimate of health risks attributable to human exposure to lead).

240. See MCGARITY, supra note 27, at 271-91.

241. See Subcommittee to Probe OMB Role in Decision, INSIDE EPA, March 15, 1985, at 9.

242. David Burnham, Suit Challenges U.S. in Revision of a Safety Rule, N.Y. TIMES, Apr. 10, 1985, at A19; Petitioners' Brief on Petition for Review to the Occupational Safety and Health Administration, Public Citizen Health Research Group v. Rowland (D.C. Cir. 1985) (Civ. Nos. 841252 \& 85-1014) [hereinafter Rowland Brief].

243. Executive Order 12,291 originally specified the President's Task Force on Regulatory Relief as the entity to which agencies should lodge appeals from adverse OMB review actions. Agencies 
Indeed, even formalized attempts at regulatory negotiation, which can greatly reduce the time and resources devoted to rulemaking initiatives, have been stymied because of long delays and last-minute resistance by OMB. ${ }^{244}$

Perhaps more than any other aspect of the current regulatory process, OMB review induces agencies to find alternatives to informal rulemaking for regulating private conduct. Agency officials complain that the prospect of critical OMB review exerts a powerful disincentive to issue regulations that would increase regulatory burdens. ${ }^{245}$ In the frank assessinent of former EPA Administrator Thomas, "OMB is important but they are more of a pain in the ass because it takes a long, long time to get anything through ...."246 Although most rules sail through the OMB review process untouched, ${ }^{247} \mathrm{OMB}$ review may nevertheless have a chilling effect on agency attempts to implement statutory commands that is not reflected in a simple count of cases in which OMB has prevailed in interagency disputes.

The aggressiveness, and occasional arrogance, of OMB's attempts to micro-manage agency rulemaking initiatives has also precipitated frequent clashes with congressional subcommittees intent on preserving their influence over agency rulemaking imitiatives. In late 1985, several meinbers of Congress introduced the "Rule Making Information Act of 1986."248 The bill would have required agencies to maintam for every

used this route only on extremely rare occasions. In one prominent case (OSHA's hazard identification regulation), the Task Force strongly resisted resolving the interagency dispute, urging the warring parties to resolve the dispute among themselves. See McGARIrY, supra note 27, at 99-100. Perhaps because it was so hittle used, the Task Force was disbanded in the second Reagan Administration. President Bush created the Competitiveness Council, headed by Vice-President Quayle, to perform roughly the same functions as the old Task Force. See Martin Memorandum, supra note 217.

244. OSHA, OMB Finishing Work on Proposal; CMA, Steelworkers Criticize Year-Long Delay, 18 O.S.H. Rep. (BNA) 570 (July 27, 1988).

245. The author has conducted dozens of interviews with agency officials in EPA, OSHA, NHTSA, and USDA in the course of writing books on regulatory analysis and OSHA. The officials are almost unanimons in their view that the prospect of $O M B$ review operates as a disincentive to promnlgate new rules that increase regulatory burdens. See MCGARITY, supra note 27, at 271-91; MCGARITY \& SHAPIRO, supra note 28.

246. Thomas Tells of Frustration with OMB, Predicts More Rules But Urges Prevention, 19 Env't Rep. (BNA) 1617 (Dec. 9, 1988) (quoting Administrator Thomas). While the average delay caused by OMB is only about four weeks, OMB can "sit" on the rule for months or even years. OMB, After 7-Month Review, Again Stalls Plans to Okay Radwaste Guidelines, INSIDE OMB, July 16, 1982, at 8; OMB Has Been Sitting on EPA's Superfund Feasibility Study Guidance, INSIDE EPA, March 22, 1985, at 12; OMB Concerned with Costs, Delays EPA Action on Benzene Toxic Air Rules, INSIDE EPA, April 20, 1984, at 4.

247. Of the 2200 rules subinitted to OMB for review in $1989,1638(73.8 \%)$ were found to bc consistent with OMB's requirements without any change. For EPA, however, only 97 of 201 rules (48.3\%) were approved without change. Regulatory ProgRAM, supra note 231, at 636, 638.

248. S. 2023, 99th Cong., 2d Sess. (1986). 
rule a file containing drafts of regulations sent to $\mathrm{OMB}$, any substantive changes in the proposals inade in response to OMB, and a summary of all written or oral communications between EPA officials and OMB that resulted in recominendations for change to the rule. However, it was limited to EPA communications and stood virtually no chance of enactinent over President Reagan's certain veto. The Chairmen of the House Appropriations and Energy and Commerce Committees, nevertheless, accomphished roughly the same result by threatening to cut OMB's appropriation for regulatory review. As a result, OMB agreed to: (1) make draft notices sent to OMB available after publication in the Federal Register; (2) inake written (but not oral) communications between OMB and EPA available at the same time; and (3) send EPA all materials that OMB received from outside parties and invite EPA to all meetings with outside parties. ${ }^{249}$

In 1989, when the statute authorizing the paperwork review functions of the Office of Information and Regulatory Affairs (OIRA) caine up for reauthorization in Congress, $\mathrm{OMB}$ agreed to go a step further, rather than risk statutory restrictions on OMB review. In a "sidebar" agreement with Congressinen Conyers and Horton, OMB Director Darman agreed to an "Administrative Agreement Outlining Procedures Governing OIRA Review of Regulations Under Executive Order Nos. 12,291 and 12,498," under which OMB would create a "public docket" for every rule submitted for inclusion on the regulatory agenda and for every rule reviewed by OIRA under Executive Order 12,291. The docket was supposed to contain a copy of all written inaterial, mcluding drafts of any proposed agency activity, exchanged between OIRA and the agency. In addition, if changes were made as a result of OIRA review, OIRA was required to place a detailed written explanation for all substantive changes in the docket, which would becone available for public inspection on the date of publication of the Advance Notice of Proposed Rulemaking (ANPRM), Notice of Proposed Rulemaking (NPRM), or final rule. OIRA also agreed to inform the relevant agency of all oral communications between OIRA and persons who were not employees of the federal government concerning that agency's rules; further, only the director and the deputy director of OIRA were empowered to engage in such outside communications. Fimally, the agreenent provided that

249. Memorandum from Wendy L. Gramm, Administrator, OIRA, for the Heads of Departments and Agencies Subject to Executive Orders Nos. 12,291 and 12,498 (June 13, 1986), reprinted in REGULATORY PrOGRAM, supra note 231, at 605; Revised Memorandum from Wendy L. Gramm, Administrator, OIRA, for the Heads of Departments and Agencies Subject to Executive Orders Nos. 12,291 and 12,498 (Aug. 8, 1986), reprinted in INSIDE THE ADMINISTRATION, Aug. 14, 1986, at 4; see Bruff, supra note 105, at 582-83. 
OIRA review of proposed and final rules would "be expeditious and conform with deadlines imposed by statute, judicial order or administrative agreement." Reviews of proposed or final rules would be completed within sixty days following receipt by OIRA, with a possible extension for an additional thirty days. 250

The agrecment dissolved, however, when the White House took the firm position that the agreement "would fundamentally impede the president's conduct of his constitutional responsibility."251 Although somewhat more open to public scrutiny than it once was, the OMB and the Council on Coinpetitiveness review processes continue to impose a significant drag on the rulenaking process in the executive agencies.

\section{E. The Net Result-Ossification}

The net result of all of the aforementioned procedural, analytical, and substantive requirements is a rulemaking process that creeps along, even when under the pressure of statutory deadlines. In the absence of deadlines, the process barely inoves at all. Given all of the barriers to writing a rule in the first place, few agencies are anxious to revisit the process in light of changed conditions or new information. Knowimg that mistakes or miscalculations in rules will be very difficult to remedy, agencies are also reluctant to write innovative or flexible rules in the first instance. Consequently, an important policyinaking tool has become extraordinarily cumbersoine. Like formal rulemaking, section 553 inforinal ruleinaking may soon becoine a hittle-used rehic, invoked only when no less burdensonie alternatives for inaking and communicating agency policy are legally available.

\section{Ossification Avoidance Devices}

The prospects for informal ruleniaking niay not be as dim as the foregoing assessment indicates. Yet even if there is still a good deal of vitality left in the old pohcyınaking tool, it inay still be worth examining some available techniques for avoiding ossification in the future. In the process, care should be taken to eschew solutions that enhance flexibility to the permanent strategic advantage or disadvantage of one or more of the regnlatory players. The examination of ossification avoidance devices that follows begins with the preimse that governinent regulation of private arrangements is a legitmiate activity and that informal rulenaking is

250. Administrative Agreement Outlining Procedures Governing OIRA Review of Regulations Under Executive Orders Nos. 12,291 and 12,498, 135 CoNG. REC. E3925-26 (daily ed. Nov. 17, 1989).

251. Corrective Action Rule Dispute Continues as OMB Regulatory Review Office Faces Threat, 21 Env't Rep. (BNA) 334 (June 15, 1990) (quoting White House Counsel C. Boyden Gray). 
a useful way to bring it about. The goal is to identify tools to make it work better for all purposes.

\section{A. Management Reforms}

The first place to look for solutions to the ossification problem is the agencies themselves. A very important reason for the agencies' failure to meet statutory and administrative deadlines is Congress's failure to appropriate sufficient resources to the agencies to undertake the ambitious rulemaking tasks Congress assigns them. ${ }^{252}$ Yet even a much needed imfusion of significant additional resources imto the rulemaking process will not eliminate the ossification phenomenon. In any event, in a time of taxpayer resistance and chromic deficits, it is highly unreahistic to expect that the President will ask for substantial new rulemaking resources or that Congress will provide them.

Assuming limited rulemaking budgets for the foreseeable future, one solution is to use existing resources more efficiently. The rulemaking process im many agencies is managed im an ad hoc fashion that fails to provide necessary bureaucratic incentives and lacks mechamisms for assuring internal accountability for delays. For example, im OSHA (as in most other agencies) the responsibility for assembling supportimg information, drafting necessary documents, and responding to public comment is assigned to rulemaking "teams" composed of representatives from all of the relevant offices within the agency and from other interested entities within the Department of Labor. The "program office" that bears the ultimate responsibility for proinulgating the rule in a timely fashion provides the team leader; but that mdividual has no authority, other than the power of persuasion, over the other members of the team. Even the head of OSHA has no direct control over some important team members, such as the attorney from the Solicitor's Office in the Department of Labor. The Administrative Conference of the United States (ACUS) has recominended that OSHA establish a formal computerized "action tracking system," modeled on the system in place at EPA, for measuring the progress of rulemaking initiatives in achieving internally established milestones in the rulemaking process. ${ }^{253}$

252. See Eisner, supra note 53 , at 8 .

253. Administrative Conference of the United States, Recommendation No. 87-1, Priority Setting and Management of Rulemaking by the Occupational Safety and Health Administration, 1 C.F.R. $\$ 305.87-1$ (1992); see Thomas O. McGarity \& Sidney A. Shapiro, OSHA Rulemaking Procedures, in 1 Administrative Conference of the Umited States, Recommendations and Reports 1987, at 7a (1988) (describing EPA's action tracking system and recommending that OSHA adopt a similar system). 
Internal management reforms, like EPA's action tracking system, which have the potential to render institutional actors accountable for bottling up the rulemaking process, should be seriously pursued by the regulatory agencies. ${ }^{254}$ Their potential for resolving the ossification problem, however, is limited because they do not address the larger external factors responsible for enormously imcreased agency workloads, and because they do not address sources of ossification at the top of the bureaucratic hierarchy.

\section{B. Regulatory Negotiation}

In recent years, regulatory reformers have heralded regulatory negotiation as an attractive vehicle for avoiding inany of the costs and delays of the ossified informal rulemaking process. Acknowledging that for inost rules of any consequence the informal ruleinaking process is merely a surrogate for the pohitical process, regulatory negotiation proponents suggest that agencies invite representatives of the affected interest groups to sit down at the table to negotiate about what the contents of particular rules should be. Because all of the parties know that the price of disagreement is a protracted and expensive ruleınaking with subsequent judicial review, they are more inclined to minimize partisan posturing and to compromise on noncritical issues. ${ }^{255}$ If the parties can agree to the general contours of a rule, the agency can promulgate it with ininimal institutional effort, secure im the knowledge that the product will not be attacked in the comment period and on judicial review. The concept has been the subject of numerous studies, ${ }^{256}$ and has been strongly endorsed by ACUS. 257 Congress has recently enacted the Negotiated Rulemaking Act of 1990 to encourage agencies to engage in negotiated ruleinaking. ${ }^{258}$

Negotiated rulemaking imvolves broad discussions among all interested parties with the goal of arriving at a consensus on a proposed rule. If the chemistry is right, "[t] $]$ he give-and-take of the negotiation process

254. See Eisner, supra note 53 , at $42-43$.

255. See David M. Pritzker, Working Together for Better Regulations, 5 NAT. REsourCes \& ENV'T 29, 29-30 (1990).

256. See Philip J. Harter, Dispute Resolution and Administrative Law: The History, Needs, and Future of a Complex Relationship, 29 VILL. L. Rev. 1393 (1983-84); Philip J. Harter, Negotiating Regulations: A Case of Malaise, 71 Geo. L.J. 1 (1982); Henry H. Perritt, Jr., Negotiated Rulemaking Before Federal Agencies: Evaluation of Recommendations by the Administrative Conference of the United States, 74 GEO. L.J. 1625, 1647-67, 1682-86 (1986); Pritzker, supra note 255.

257. Administrative Conference of the United States, Recommendation No. 85-5, Procedures for Negotiating Proposed Regulations, 1 C.F.R. $\S 305.85-5$ (1992); Administrative Conference of the United States, Recommendation No. 82-4, Procedures for Negotiating Proposed Regulations, 1 C.F.R. § 305.82-4 (1992).

258. Negotiated Rule Making Act of 1990,5 U.S.C. $\S \S 581-590$ (Supp. II 1990). 
fosters creative and acceptable solutions to difficult problems."259 The agency must appomt an official to convene and organize the negotiations, and it can also appoint a mediator to facilitate agreements. Ground rules for the negotiations are established by the participants at the outset. The negotiators then meet until they have reached agreement, until they have agreed that they will not reach agreement, or until a previously imposed deadline arrives. The agency's role can range from fully participating as a negotiator to actimg as an observer and commenting on possible agency reactions and concerns. Depending on how intensely the negotiators go about their work, the entire process can consume from six months to one year. When the negotiations are successful, the agency can promulgate rules with substantial cost and time savings. In addition, hitigation can be avoided, and the agency will have an opportunity to gauge the imtensity of the parties' concerns over various issues. Moreover, the final rule should attam greater legitimacy than a rule that is the product of an adversarial battle in which one side prevails.

Regulatory negotiation may not be easily adaptable, however, to an already conflict-laden rulemaking proceedimg, as it demands that highly disparate groups reach substantial consensus. ${ }^{260}$ Negotiated rulemaking in EPA and OSHA has for that reason failed inore frequently than it has succeeded. ${ }^{261}$ Negotiated rulemaking will probably not be very useful in large generic rulemaking efforts with precedent-settimg potential or in addressing issues on which the positions of likely participants have already hardened; on the other liand, negotiated rulemaking might be entirely appropriate for new topics, such as regulating risks posed by genetically engineered microorganisms in the pharmaceutical industry, where positions have not yet been formed and where large investments have not yet been made. Negotiated rulemaking may also fail in contexts in which a large number of parties have widely divergent interests. ${ }^{262}$ Finally, a precondition to a successful negotiated rulemaking may be a relative equivalence in the power of all participants to affect the outcoine of the proceeding if the negotiations fail. A party that "holds all the cards" going into the negotiations is likely to have a disproportionate impact on

259. Pritzker, supra note 255 , at 29.

260. See Steven Kelman, Regulating america, Regulating Sweden: A Comparative Study of Occupational Safery and Health Policy 82-112 (1981); Graham K. Wilson, The Politics of Safety and Health: Occupational Safety \& Health in the UNITED STATES \& BRITAIN 151-52 (1986).

261. See Pritzker, supra note 255, at 31 (recounting failure of negotiated rulemaking in OSHA); Matthew L. Wald, U.S. Agencies Use Negotiations to Pre-Empt Lawsuits over Rules, N.Y. TIMES, Sept. 23, 1991, at A1 (quoting Chris Kirtz, chief of the consensus and dispute resolution staff at EPA, to the effect that only 12 of the 60 regulatory negotiation efforts undertaken by EPA have succeeded).

262. See Pritzker, supra note 255 , at 51. 
the output. Knowing this, weaker parties inay refrain froin participating from the very outset.

Negotiated rulemaking is a very useful tool that should be in every regulatory agency's toolbox. When applied in the proper context, it can greatly reduce the time and effort all of the parties devote to rulemaking initiatives. It is not, however, a magic cure for the ills of ossification.

\section{Avoiding Informal Rulemaking}

1. Policymaking Through Adjudication. Those agencies that have a choice can attempt to avoid rulemaking ossification by making policy in individual adjudications. ${ }^{263}$ For example, the NLRB has for the most part rehed on adjudications to make regulatory pohicy throughout its history, and the Supreme Court has overturned lower court attempts at forcing that agency into the rulemaking mold. ${ }^{264}$ Adjudication allows an agency sufficient flexibility to make policy incrementally on a case-bycase basis. As long as the adjudicatory record supports the specific action, the agency can avoid explaining the factual and policy underpinnings for the broad rules it articulates im adjudication. The agency can also sidestep many of the broad analytical requirements of the Regulatory Flexibility Act and the relevant executive orders, none of which apply to agency adjudication.

Switching to an adjudicatory mode does not, however, avoid cumbersome procedures. Informal rulemaking, after all, was desigued in part to avoid the time and expense of adjudicatory procedures. Also, policymaking through adjudication may result im less effective public participation, as it is very difficult to accommodate the widely varying interests that are affected im polycentric policy disputes within the narrow strictures of the adjudicatory model. ${ }^{265}$ Nor is the agency as accountable to Congress and the public when it makes regulatory policy through adjudication. Finally, the individual subject of the first adjudication to establisli a broad regulatory policy may consider himself to be unfairly treated when the agency had the alternative of notifying all regulatees of its thinking and eliciting their comments.

Greater reliance on adjudication is not a reasonable solution to the ossification problem. Most of the modern agencies do not even have the

263. See Scalia, supra note 1, at 27 ("It is almost inconceivable that all these changes will not induce the wily (or even moderately intelligent) bureaucrat to do more of his thing through adjudication instead of rulemaking, if he is free to do so.").

264. NLRB v. Bell Aerospace Ca, 416 U.S. 267 (1974); see Mark N. Grunewald, The NLRB's First Rulemaking: An Exercise in Pragmatism, 41 DUKE L.J. 274 (1991).

265. Kenneth C. Davis, Administrative Law Treatise $\S 7.6$, at 33 (2d ed. 1978) ("The procedure of formal adjudication is [an] atrocious procedure for policymaking affecting the multitude."). 
option to choose between adjudication and rulemaking, and those that do should not be encouraged to elect adjudication over rulemaking. Rather than giving up on informal rulemaking, the agencies and Congress should be attempting to pluck it from the morass in which it currently finds itself.

2. Policymaking Through Less Formal Vehicles. Another way to sidestep the additional procedural, analytical, and substantive hurdles of informal ruleunaking is to channel policymaking into less formal vehicles, such as policy statements, interpretative rules, and guidance documents. Although exempt from section 553's procedures, these devices still put regulatees on notice of what the regulator expects of them. ${ }^{266}$ Because it avoids all of the procedures, analyses, and judicially imposed record-assembling requirements of notice-and-comment rulemaking, this approach would no doubt consume far fewer agency resources. The agency imight therefore be inuch more willing to undertake new and innovative rulemaking initiatives. Finally, resort to less formal pohicymaking tools would inaximize the agency's flexibility to change its mind and to amend its policy in the future by merely changing its policy or interpretation in the same spontaneous way it first issued the policy.

Rehance on less formal policymaking mechamisms could, however, severely reduce public participation in the policyinaking process. ${ }^{267} \mathrm{~A}$ large-scale inoveinent away from the section 553 inodel and toward these less formal devices would therefore represent an unwelcoine return to unaccountable government. Unlike informal rules, which become effective ouly after public notice-and-comment, these less formal mechanisms

266. See Asimow, supra note 6. Asimow distinguishes between legislative rules and interpretative rules:

The theoretical difference between legislative and nonlegislative rules is clear. A legislative rule is essentially an administrative statute-an exercise of previously delegated power, new law that completes an incoinplete legislative design. Legislative rules frequently prescribe, modify, or abohsh duties, rights, or exemptions. In contrast, nonlegislative rules do not exercise delegated lawmaking power and thus are not administrative statutes. Instead, they provide guidance to the public and to agency staff and deeisionınakers. They are not legally binding on meinbers of the public.

Interpretive rules and policy statements serve distinct functions. An interpretive rule clarifies or explains the meaning of words used in a statute, a previous agency rule, or a judicial or agency adjudicative deeision. A policy statement, on the other hand, indicates how an agency hopes or intends to exercise discretionary power in the course of performing some other admimistrative function. For example, a policy stateinent might indicate what factors will be considered and what goals will be pursued when an agency conducts investigation, prosecution, legislative rulemaking, or formal or informal adjudication.

Id. at 383. The discussion that follows addresses nonlegislative rules.

267. See Robert A. Anthony, "Well, You Want the Permit, Don't You?" Agency Efforts to Make Nonlegislative Documents Bind the Public, 44 ADMIN. L. REv. 31, 32 (1992). 
can take regulatees and beneficiaries by surprise.268 Although the legal and factual bases for interpretative rules, policy statements, and guidance docuinents can usually be challenged during judicial review of a permit or enforcement action, the unwelcome practical consequences of failure may induce regulatees to refrain from challenging unsupported agency pontifications. ${ }^{269} \mathrm{~A}$ wholesale shift to these less formal devices could leave regulatory agencies much less accountable to the public and could pave the way to arbitrary decisionmaking. 270 Finally, after President Bush's recent expansion of the scope of the OMB review process to include "all agency pohicy guidance that affects the public," switching to less formal vehicles to inake regulatory pohicy will probably not avoid one of the largest obstacles to effective rulemaking. ${ }^{271}$

Agencies could remedy the accountability problein to some extent by soliciting notice-and-comment on interpretative rules, policy stateinents, and guidance documents prior to issuing them in final forin. Yet while this adaption would yield some greater degree of openness and accountability, it would not provide a pre-enforcement opportunity to challenge the legal and factual basis for the potentially binding norn, thereby allowing the agency to avoid the burden of justification. Perhaps more important, adding a notice-and-comment requirement to the less fornal techniques would invariably raise the question of where to stop. Agencies engage in countless pohicy calls and interpretations in dealing with individual regulatees, as well as in inore general settings like memoranda

268. See id. at 39 (arguing that "[p]eople rightly resent being surprised by new interpretations that the government suddenly pulls out of its nonlegislative hip pocket, especially when they cannot do anything about them").

269. See id. at 33 ("At its worst, this is government by intimidation. If the document is an internal memo to staff that is not published, there is the additional problem of secret law, whereunder affected parties do not know the principles by which their affairs are governed unless they have back-channel sources within the agency.").

270. Professor Davis argues that "courts can and should whittle down the huge exceptions for interpretative rules, procedural rules and general statements of policy." DAVis, supra note 265 , $\S 7.6$, at 35 .

271. It did not take loug for OMB to discover this covert vehicle for avoiding its input into admimistrative policymaking. In March, 1991, Vice-President Quayle circulated a memorandum to all executive agencies requiring a rulemaking impact analysis and OMB review for "all agency policy guidance that affects the public," including "strategy statements, guidelines, policy manuals, grant and loan procedures, Advance Notices of Proposed Rule Making, press releases and other documents announcing or implementing regulatory policy that affects the public." Memorandum from the Vice President for Heads of Executive Departments and Agencies 1 (March 22, 1991). If the executive agencies had taken this directive seriously, OMB would have soon become inundated with submissions of such informal policymaking devices. Almost any policy guidance document has the potential to affect the public. In practice, the requirement gave OMB the discretion to choose from among the thousands of submissions those for which OMB staffers had a particular antipathy or those suggested for close review by affected industries. 
from program office work groups to inspectors in the field, and draft responses to congressional inquiries. Once the agency establishes a process for ehciting public comment on these informal renderings, it will be difficult to decide which should be included in the process and which should be outside it. ${ }^{272}$

In the final analysis, shifting to less formal pohicymaking vehicles is merely another way of avoiding, rather than solving, the ossification problem. The goal should be to make the inodel function more flexibly and efficiently, not to abandon it entirely.

\section{Changing Informal Rulemaking Procedures}

Congress could meet the ossification problein head-on by amending the APA to render informal rulemaking even less formal than it is now. It is difficult, however, to see how the informal rulemaking process could be made inuch simpler. For example, soine agencies like OSHA beheve that their own statutes mandate a somewhat inore formal hearing than the "paper liearing" envisioned by section 553. Congress could ainend particular statutes to make its intent clear that formal hearings are not necessary in particular contexts. But aside from this relatively inodest course of action, informal rulemaking cannot likely be inade much less formal procedurally. Given that purely procedural requirements do not contribute greatly to the burdensoneness of informal rulemaking, this minor suggestion is probably not worth pursuing.

\section{E. Reducing Analytical and Information Requirements}

1. Findings and Reasons. Congress could amend section 553's "concise general statement of basis and purpose" requirement to signal its intent that an agency need not explam the factual and policy bases for a rule with the degree of particularity that the courts have previously required.273 At the same time, Congress could write statutory language indicating that agencies need not respond to every coininent and criticisin that accompamies a blunderbuss attack on the technical underpinnings for their rules.

We have seen that preparing a reasoned explanation can be very resource-intensive and time-consuming, and the prospect of having to respond to blunderbuss attacks by regulatees can be a significant disincentive to agency action. The proposed amendinents would allow the

272. See Asimow, supra note 6 , at 408 (arguing against incorporating notice-and-comment into the promulgation of interpretative rules and policy statements).

273. Congress could similarly amend the individual agency statutes that provide specific requirements for agency explanations of the bases for their rules. 
agencies to spend their scarce resources gathering data on the critical issues and responding to the comments that they deem especially relevant without worrying about the prospect of judicial reversal for failing to have a study to cite for cvery factual inference or neglecting to rebut every unsupported allegation. The agencies are likely to promulgate more rules and to revisit old rules more frequently if the burden of explaining changes to the status quo is thus reduced.

The requirement that an agency explain itself, however, can be an effective and relatively inexpensive curb on arbitrariness and rehance upon extra-legal considerations. ${ }^{274}$ Even in the absence of other review mechainsms, the requirement for reasoned explanation ensures that the range of agency action is bound by those options that are supportable by facts $i m$ the record, reasonable assumptions, and sound policy considerations-and this is the case whether or not the reasons the agency gives are the real reasons that motivate the agency. The requirement that the agency explam itself also apprises affected parties of the legal, factual, and policy bases for the regulation. To the extent that agency rules depend upon critical assumptions and inferences from the existing data, requiring the agency to lay out those assumptions and inferences, and to subject them to outside scrutiny, will enhance the accuracy and legitimacy of the resultimg rule. Similarly, the requirement that the agency respond to significant comments helps legitimate the process in the minds of affected parties, even if the agency resolves issues adversely to them.

The virtues of reasoned explanation almost certainly outweigh the costs. The problem does not he im the minimal requirements inherent in the words "concise general statement of basis and purpose." Rather, it hes in overly aggressive judicial apphication of the findings and reasons requirement to overturn rules that are as well supported as the available information reasonably allows.

2. Specific Analytical Requirements in Agency Statutes. Congress could also consider amending individual agency statutes to eliminate some of the more burdensome analytical requirements and make clear that the agency need not accomphish specified analytical steps with the rigor of academic science. This change would free up agency resources for inore rules and would reduce the disincentive to revisit old rules. In truth, much of the effort that goes into congressionally required analytical exercises is mere paperwork, consistimg primarily of post hoc rationalizations for decisions reached on inore pragmatic grounds. It is usually

274. See Saginaw Broadcasting Co. v. FCC, 96 F.2d 554, 559 (D.C. Cir.), cert. denied, 305 U.S. 613 (1938). 
impossible to tell whether the analytical exercises actually had an impact on the agency's substantive decisions.

On the other hand, specifying analytical requirements in agency statutes is one of the few techniques that Congress has left for guiding the exercise of administrative discretion. Specific analytical requirements can ensure that certain kinds of information and analysis are on the table for the agency's consideration, even if the agency is not always guided by the analyses. Moreover, eliminating specific analytical requirements may mcrease the agency's discretion to base regulatory decisions on mappropriate "political" considerations.

There is no reason for an agency to undertake analysis for the sake of analysis. Yet because Congress is unlikely to abandon this modest degree of control over agency discretion, any flexibility-enhancing change will probably have to come from the courts by way of reducing the stringency of their review of the agencies' adherence to specific analytical requirements. Since the content of specific statutory analytical requirements is usually a matter of statutory interpretation, attenuated judicial scrutmy of the agency's complance with such requirements would be consistent with the deferential approach to statutory interpretation announced in Chevron.275 At the very least, the courts should not read into statutes analytical requirements that are not compelled by the statutory language, as the Supreme Court arguably did in the Benzene case when it found a "significant risk" test in the requirement that OSHA ensure that employees work in a "safe" environment. 276

\section{General Analytical Requirements in Government-Wide Statutes} and Executive Orders. Congress could enact legislation to reduce or eliminate the one or nore of the many general analytical requirements in statutes and executive orders. In many, if not most, major rulemakings,

275. The Court in Chevron held that courts should be deferential to the agencies' interpretations of congressional statutes:

[I]f the statute is silent or ambiguous with respect to the specific issue, the question for the court is whether the agency's answer is based on a permissible construction of the statute. ... If Congress has explicitly left a gap for the agency to fill, there is an express delegation of authority to the agency to elucidate a specific provision of the statute by regulation. Such legislative regulations are given controlling weight unless they are arbitrary, capricious, or inamifestly contrary to the statute. Solnetimes the legislative delegation to an agency on a particular question is inplicit rather than explicit. In such a case, a court may not substitute its own construction of a statutory provision for a reasonable interpretation made by the admimistrator of an agency.

Chevron U.S.A. Inc. v. Natural Resources Defense Council, Inc., 467 U.S. 837, 843-44 (1984).

276. For a critique of this aspect of Benzene, see Thomas O. McGarity, Beyond the Hard Look: A New Standard for Judicial Review, 2 NAT. RESOURCES \& ENV'T 32 (1986). 
the agencies perceive these special analytical requirements to be meanmgless paperwork hurdles, rather than useful decisionmaking tools. ${ }^{277}$ An agency is most interested im analyzing issues that are directly relevant to the success or failure of the rulemaking initiative in the relevant judicial and political arenas. Eliminating marginally useful analytical requirements would probably not reduce the imtensity of an agency's analysis of the pertiment issues. Simce the process of producing analytical paperwork is both time-consuming and expensive, the rulemaking process inight move along more expeditiously.

The designers of these analytical tools, however, apparently behieved that they would guide the agencies to better decisions. Yet some of the analytical tools either are not neutral on their face or are not neutrally applied im practice. For example, the takings analysis is largely irrelevant to deregulatory initiatives, and the RIA requirement, as adıninistered by OMB, is only an inipediment to new regulations or changes increasing the stringency of existing regulations. ${ }^{278}$ Similarly, when it became clear that regnlatees were attempting to use the EIS requirement to hamstring EPA's efforts to iniprove the environment, Congress and the courts exempted most EPA rulemaking initiatives from that process. ${ }^{279}$ Although it is clear that some of the externally iniposed analytical requirements contribute hittle to the quality of agency decisionmaking, it is difficult to identify in a neutral way the requireinents that ought to be eliminated and those that serve useful functions in guiding agency discretion.

Some techniques exist for reducing the burdensomeness of analytical requirements while retaining their contribution to the agency's thinking process. For example, the burdensomeness of the EIS requirement can be ameliorated in three ways. First, a regulatory agency can often shift the burden of conductimg the studies and preparing the initial analyses to the private entities subject to their regulatory authority. ${ }^{280}$ Second, when it decides to revisit old rules, an agency can usually satisfy NEPA by preparing a less burdensome Environmental Assessment or Supplemental EIS. ${ }^{281}$ Third, an agency can develop simplifying techniques like the

277. See Joseph L. Sax, The (Unhappy) Truth About NEPA, 26 OXLA. L. Rev. 239, 239 (1973) (arguing that the analytical requirements of NEPA produce virtually no benefits to offset the added burdens they place on the agencies).

278. See McGarity, supra note 27, at 281-88 (discussing disadvantages of $\mathrm{OMB}$ intervention).

279. BONINE \& MCGARITY, supra note 123, at 63 n.3.

280. See MANDELKER, supra note 89, at $\S 7.03-.04$. The RFA requirement cannot be delegated so easily.

281. See id. $\S 8.46$. Although I am aware of no similar suggestion that a full-blown RFA could be avoided for a change of an existing rule by preparing a "Supplemental RFA," there in no good 
"tiering" concept under which the agency prepares a broad generic analysis of general issues and later prepares less extensive, but more detailed, analyses of individual actions that simply cite the larger studies on the generic issues. 282 There is no reason why this process could not be adapted to RIAs, RFAs, takings analyses, federalism analyses, and other similar analytical requirements. Alternatively, an agency could negotiate with the affected parties im advance about the content of the analyses. This could avoid acrimonious debates later about whether the analyses addressed the right issues.

Because intense analysis of the costs and benefits of proposed and final regulations is more useful in some areas than in others, Congress and the President might usefully explore the possibility of reducing or eliminating certain aspects of the analytical requirenients in certain regulatory areas. For example, monetizing the benefits of health and environinental regulation is exceedimgly speculative and controversial. The flexibility of the rulemaking process might be enhanced if agencies were allowed to make only qualitative comparisons of costs and benefits after having undertaken quantitative analyses of costs and risks. Whether the benefits of analyzing the impact of regulations on small entities are outweighed by the negative impact of such analytical requirements on the flexibility of rulemaking is fairly debatable. The additional benefits of an analysis focused particularly on small entities are probably not very high, but the burden is likewise not very great. Congress should revisit the Regulatory Flexibility Act to form some conclusions as to whether that statute is reducing flexibility, rather than enhancing it. Finally, the very marginal benefits of the takings analysis, family analysis, and federalism analysis are not likely worth the additional inertia that they interject into the process.

\section{F. Eliminating or Modifying Outside Scientific Review}

Although outside scientific review has sometimes been imposed by Congress on reluctant agencies, it has ordinarily originated in the agencies' own misgivings about the quality of the data upon which they were relying and the validity of the scientific inferences they were drawing. To the extent that the agencies perceive that they need neutral outside help to reach sound decisions, it would be unwise to deprive then of this useful and relatively inexpensive source of expertise. On the other hand, the

reason in principle why the concept could not be imported from NEPA to the Regulatory Flexibility Act.

282. See 40 C.F.R. $\$ 1508.28$ (1991). 
proliferation of advisory committees, and the perception that private advisors were making government policy, were instrumental in bringing about the enactinent of the Federal Advisory Committee Act, which requires that all advisory committees to federal agencies be periodically chartered and that their meetings normally be open to public scrutiny. ${ }^{283}$ Given the capacity of advisory committees to delay ongoing rulemaking initiatives, agencies should not charter them unnecessarily, and Congress should be wary of inposing advisory committees on agencies where the agencies theinselves do not perceive a need for it.

\section{G. Reducing the Intensity of Substantive Review}

Most of the tinie consumed in the rulennaking process is devoted to preparing the supporting documentation for agency decisions in anticipation of review by $\mathrm{OMB}$, congressional committees, and the courts. Reducing the stringency of outside institutional review could greatly enhance agency flexibility, but it would come at the cost of decreased accountability.

1. Executive Review. For the last twelve years, the White House and several congressional committees have battled over the intensity of $\mathrm{OMB}$ review of ruleinaking. Because the analytical requirements of the executive orders and the Regulatory Flexibility Act are not subject to judicial review, review by some institution like OMB is probably necessary to ensure that agencies do not completely ignore their analytical obhigations. Otherwise, agencies' analytical efforts would no doubt degrade into post hoc rationalizations of decisions reached on different, and perhaps hidden, grounds. Although the fornal OMB process is probably not necessary in the case of every major rule to ensure the overall quality of regnlatory analysis, an OMB check on the quality of agency analysis is probably useful in the same sense that EPA review of enviroumental impact statements helps keep the agencies honest.

The primary objection to substantive OMB review is that it looks beyond the quality of agency analysis to the substance of agency decisions, and it does so in a way that tends to be secretive and unaccountable. Agencies are understandably reluctant to cede decisionmaking authority to $\mathrm{OMB}$, and Congress is equally hesitant to allow the President to exercise so much unconstrained power over the direction that the agencies take in iniplementing congressional goals. Much of what motivates the agencies to attempt to circumvent the rulemaking process is the

283. 5 U.S.C. app. $\S \S 10(a)(1), 14$ (1988). 
prospect of dealing with the acrimonious and time-consuming process of OMB review.

It is unlikely that Congress will attempt to cut agencies off from executive review entirely. Congress is mcapable of monitoring the rulemaking process closely enough to keep agencies accountable, and it no doubt recognizes that the President stands in a unique position to ensure that agency rules adhere to congressionally articulated policies. Unfortunately, the recent history of OMB review denonstrates that it can also be used to advance extrastatutory policies tliat can deflect the agencies from their prescribed mandates. OMB review should therefore be used only sparingly for politically important rules, and it slould not be used in a heavy-handed fashion to steer agencies away from statutory policies.

Abuse of the process can be limited, and its accountability enhanced, by making the contents of OMB-agency communications public. In recent years, OMB has, under threat of lost appropriations, acceded to congressional demands that it reveal more about the nature of OMBagency imteractions. In 1986, under a serious threat to appropriations to OIRA, OMB agreed to make available "upon written request" copies of any ANPR, NPR, or final rule submitted to OMB, and all written correspondence concerning such drafts between OMB and the agency. However, OMB agreed to this only after publication of the relevant docunient in the Federal Register. ${ }^{284}$ In 1989, witl its statutory authorization in jeopardy, OMB imitially agreed to a "sidebar agreennent" containing still further requireinents and aimed at opening up the OMB review process; the White House, however, intervened and killed the deal. ${ }^{285}$ The White House thus continues to invoke executive privilege in resisting attempts at increasing the openness of the process. Congress doubtless has the power to open up the process to even greater public scrutiny, ${ }^{286}$ and it should do so. 287

284. See supra text accompanying notes $242-43$.

285. See supra text accompanying notes 250-51.

286. See Thomas O. McGarity, Presidential Control of Regulatory Agency Decisionmaking, 36 AM. U. L. REV. 443, 489 (1987).

287. See National Academy of Public Administration, Presidential Management OF RULEMAKING IN REgULATORY AGENCIES 35 (1987) (recommending that "regulatory agencies $\log$, summarize, and include in the rulemaking record all communications from outside parties, $\mathrm{OMB}$, or other executive or legislative branch officials concerning the merits of proposed regulations"). The Administrative Conference of the United States has recommended a slightly less revealing disclosure of any draft proposed or final rule and any additional formal analyses submitted for OMB review at the time when the proposed or final rule is published. The recomnendation provides that when the agency terminates the rulemaking after having published a notice of proposed rulemaking, "agency submissions to the office responsible for presidential review and any additional formal analyses submitted for review should be made available to the public when the 
OMB review will be inuch less intrusive if the contents of OMBagency coinununications are spread out on the public record for all to see. When OMB staffers know that the time consuned in the OMB review process and the extent to which OMB staffers attempt to substitute their policy preferences for those of the appointed agency heads and of Congress will be revealed to the public, they may be less likely to use the review process as a vehicle for effecting substantive agency policy. If OMB review is properly limited to review of the agencies' analyses and public comment on the agencies' reasoning processes, the agencies will not feel so reluctant to send proposals into that process, and a great impediment to the flow of congressionally authorized regulations should be substantially diminished. ${ }^{288}$

2. Congressional Review. Direct congressional review of agency procedures and analyses is so rare and unobtrusive that it warrants little attention. To the extent that Congress is inclined to dabble in agency analytical efforts, it may be better suited for broad prograinmatic analyses in committee reports, Office of Technology Assessment reports, and General Accounting Office reports. These broad analyses may tie up agency decisionınakers' time with testimony on the Hill and fretting with congressional staffers, but they do not impede the rulennaking process.

Substantive congressional review of agency rules tends to be sporadic but effective. A sharply critical congressional hearing directed at a current rulemaking imitiative can easily derail it or substantially affect its substantive outcome. Focused congressional inquiry and attention can enhance the agency's accountability to all of the citizenry and can be especially effective in stimulatimg the process, getting it off of dead center. ${ }^{289}$

decision to terminate is announced." Administrative Conference of the United States, Recommendation No. 88-9, Presidential Review of Agency Rulemaking, 1 C.F.R. $\S 305.88-9$ (1992). The recommendation does not suggest how the public is to ascertain when a rulemaking initiative has been "terminated," instead of consigned to the "purgatory" of an indefinite OMB review. See also Bruff, supra note 105, at 595 (recommending a "paper trail" of OMB rulemaking activities). But see Pierce, supra note 206 at $\mathbf{5 2 0}$ (arguing against proposals to limit presidential review of rulemaking on the ground that the President is the only institution other than the courts capable of adequately confining the discretion of regulatory agencies).

288. It is possible that the current Administration is beginning to substitute rcview by the staff of the Council on Competitiveness for OMB review in order to avoid some of the limits on secrecy that OMB has been forced to observe. See Congressional Scrutiny of Quayle Reg Reviews Likely to Displace OMB Focus, INSIDE EPA, Sept. 13, 1991, at 3; Quayle Council to Kcep Close Tabs on Development of EPA Clean Air Rules, BNA WASH. INSIDER, March 22, 1991, available in LEXIS, BNA Library, BNAWI File. To the extent that this happens, Congress should likewise linit secret intervention by the Council on Competitiveness into the rulemaking process.

289. See, e.g., Barry W. Weingast \& Mark J. Moran, Bureaucratic Discretion or Congressional Control? Regulatory Policymaking by the Federal Trade Commission, 91 J. PoL. Econ. 765 (1963) 
On the other hand, Congressional hearings directed at ongoing rulemaking topics can be very disruptive. They pull the staff away from the task at hand to prepare testimony that must of necessity be equivocal, as the agency cannot convey the impression that the outcome of the rulemaking process is predetermined. Worse, congressional hearings can interject partisan pohtical considerations that are not necessarily geared toward producing a rational outcome. Fimally, the anticipation of negative congressional oversight can cause agencies to refrain from adopting mnovative and flexible approaches to regulation.

In the final analysis, however, congressional oversight hearings on ongoing rulemaking topics occur infrequently enough that they probably do not contribute significantly to the ossification of the rulemaking process. The potential that congressional hearings have to stimulate moribund rulemaking imitiatives and to pressure agencies to reexamine poorly conceived existing rules probably outweighs the in terrorem effect of congressional review on new rulemaking efforts. 290

3. Judicial Review. In the wake of Vermont Yankee, the courts have been appropriately cautious about imposing additional procedural barriers to rulemaking. Judicial review of the adequacy of agency analytical efforts is generally limited to evaluating the adequacy of environmental impact statements, and that review is usually quite deferential. ${ }^{291}$ Modifications in the nature of substantive judicial review under the arbitrary and capricious test could, however, help solve the ossification problem.

The prospect of substantive judicial review can be a great tonic to the agencies. ${ }^{292}$ Agency decisionmakers are less likely to act irrationally when they know that a body composed of intelligent neutral laypersons must feel coinfortable in concluding that the agency confined itself to its

(describing the influence of congressional committees over FTC during the 1970s). See generally, LaWrenCe Dodd, Congress and the Administrative State (1986).

290. See, e.g., Michael Pertschuk, Revolt Against Regulation: The Rise and Pause OF THE CONSUMER MOVEMENT 69-117 (1982) (discussing complaints of former Chairman of FTC concerning disruption of agency rulemaking initiatives caused by congressional committees).

291. See, e.g., Baltimore Gas \& Elec. Co. v. Natural Resources Defense Council, Inc., 462 U.S. $87,97-98$ (1983) ("The role of the courts is simply to ensure that the agency has adequately considered and disclosed the environmental impact of its actions and that its decision is not arbitrary or capricious."). See generally BoNINE \& MCGARITY, supra note 123, at 138-86.

292. See William F. Pedersen, Jr., Formal Records and Informal Rulemaking, 85 YALE L.J. 38, 60 (1975); Strauss, supra note 220, at 539; Sunstein, supra note 75, at 527. 
statutory authority, sought to achieve the statutory goals, applied its expertise to technical problems in a bona fide way, and responded to significant objections from potentially affected persons. ${ }^{293}$ Indeed, the mere possibility of substantive judicial review alone can be a great hedge against arbitrariness, even if it does not occur in every case. ${ }^{294}$ Judicial review can broaden the "tunnel vision" that so often afflicts single-issue agencies. Moreover, judicial review can steer agencies back on the track when they stray froin their congressionally assigned roles. ${ }^{295}$ In suin, judicial review can perform a necessary "quality control" function. ${ }^{296}$

At the same time, the judges should be especially cautious in performing their substantive review functions for three important reasons. First, there are clear limits to judicial competence in the area of highly scientific and technical ruleınaking. ${ }^{297}$ Not all judges have the extraordinary intellectual capacity of Judge Levanthal, who originally coined the phrase "hard look."298 Even if they did, the judges could not possibly educate themselves about all of the arcane scientific, technical, and econoimic issues that dominate a typical scientific rulemaking, especially when they inust depend to a large degree upon interested parties to be their teachers. Second, considerations of institutional power demand judicial circumspection. Stringent substantive judicial review can frustrate the impleinentation of congressionally articulated pohicies. Inconsistency ainong courts and among panels within a single court can lead the agencies to go to extreine and expensive lengths to justify their actions. Third, stringent substantive judicial review can hamper innovation and experimentation. Agencies will be dismclined to experiment when they

293. See Strauss, supra note 220 , at 542 (arguing that "[i]udicial review, like hearings, serves a number of functions that aren't captured by talking about programmatic impact-providing some assurance of fairness to and recognizing the dignity and worth of individual participants; encouraging the sense of being heard; [and] controlling the legality of particular governmental action").

294. Judge Wald believes that the intense judicial effort that went into reviewing the EPA's new source performance standard for coal-fired steam electric power plants was worth the effort because "the agency was put on notice that, within the lumits of an irritable generalist, its decisions were being moritored." Wald, supra note 123, at 77.

295. See Garland, supra note 7, at 591 (discussing the important role of the courts in ensuring "agency fidehty to congressional intent").

296. See Stephen G. Breyer \& Richard B. Stewart, Administrative Law and ReguLATORY POLICY 307 (1979).

297. See Shapiro, supra note 60, at 1507 ("Courts cannot take a hard look at materials they cannot understand nor be partners to technocrats in a realm in which only technocrats speak the langnage."); Strauss, supra note 220, at 550 ("Coming to grips with a world of statutes that do not in fact have fixed meamings, of complex technological problems that do not have demonstrably correct answers, means that we can expect hittle more from agencies than careful deliberation and prudence-and the role of the courts in this politieal context should be no inore ambitious than to encourage those qualities.").

298. See supra note 123. 
know that the effort may wimd up being thrown back at them by unsympathetic judges.

Reducing the intensity of substantive judicial review would probably enhance rulemaking flexibility, but it would also leave more room for administrative arbitrariness. We are therefore left with a dehicate balance. In the past, soine courts have been too inclined to intrude into the scientific and technical substance of rulemaking; but there is some evidence that judicial review in the lower courts has grown inore deferential in the last several years. If this is true, then the problem may cure itself as agency perceptions catch up with judicial realities. To send the right signal to the agencies, the courts inight pay careful attention to the metaphors of judicial review as well as to the realities.

It may be tinie for the courts to replace the "hard look" metaphor with a more deferential inrage. ${ }^{299}$ Judge Wald, who has filled Judge Levanthal's role as one of the most thoughtful students of administrative law on the D.C. Circuit, has suggested that a more appropriate metaphor inight assign courts the role of "nursemaid" for regulatory programs that Congress has given birth to and then abandoned. ${ }^{300}$ However, this inetaphor also suggests a role for the reviewing courts that is too intrusive. A better inetaphor for this evaluative function may be that of the "pass-fail prof" who must determine whether a research paper on a topic with which he is vaguely familiar meets the minimum standards for passable work. His disagreement with the paper's conclusions will certainly not cause him to flunk the student. Even a poor analysis will not cause the paper to fail, if it is at least plausible. A check of the citations inay reveal that the student could have found more sources or that he may have mischaracterized one of the cited sources, and still the paper will pass. Only where there is an inexcusable gap in the analysis, an obvious inisquote, or evidence of intellectual dishonesty, will the pass-fail prof give the student an " $F$ " and order the student to try again. When the courts engage in substantive judicial review, they should, like the pass-fail prof, see their role as that of screening out bad decisions, rather than ensuring that agencies reach the "best" decisions.

299. Mashaw and Harfst warn, however, that the prevailing legal culture may not support reducing the stringency of judicial review:

Judged by the specific statutory provisions for judicial review that Congress adopts, and by the proposals it debates for general reform of judicial review of administrative action, there is no substantial constituency out there for reduction or elimination of judicial review. Eclectic, uninformed and disabling as it may be, Congress, and perhaps the electorate, seem to want the legal culture, as interpreted and applied by reviewing courts and the private and public actors who look to them for guidance, to form a part of the regulatory environment.

Mashaw \& Harfst, supra note 37, at 316.

300 . Wald, supra note 126 , at 138 . 
The courts should continue the trend (if a trend does in fact exist) of reducing the stringency of substantive judicial review. If the courts fail to do so, Congress should consider enacting legislation designed to signal its intention to reduce the stringency of judicial review by ainending the APA to change the scope of review for informal ruleinaking and by amending soine agency statutes to substitute "arbitrary and capricious" review for "substantial evidence" review of rulemaking. ${ }^{301}$

\section{H. Enhancing the Ability of Outsiders to Stimulate Rulemaking}

In cases where the ossification problem is largely one of stimulating recalcitrant or lethargic agencies to action, a partial solution is to enhance the ability of outsiders to force agencies to take up rulemaking imitiatives aimed at promulgating new rules or at reexamiming existing rules. Section 553(e) of the APA allows outsiders to petition an agency to begin a rulemaking imitiative. ${ }^{302}$ Under section 553(e), the agency inust respond within a reasonable time and give its reasons for denying the petition if it does so. ${ }^{303}$ Judicial review of the agency's refusal to imitiate rulemaking is possible, but it is very limited. ${ }^{304}$ In addition, many of the inodern agency statutes require that certain rules be promulgated by specific statutory deadlines, and they provide for direct actions in district court to force the agency to honor those deadhines. ${ }^{305}$ In addition to enacting more specific deadlines in individual statutes, Congress could amend the APA to lower the threshold for mitiating rulemaking and to signal its intent that judicial review of agency refusals to imitiate or to coinplete existimg rulemakings be inore stringent in some or all circumstances.

Reducing the barriers to "bureaucracy-forcing" petitions and subsequent judicial review would no doubt increase the frequency with which agencies mitiate new rulemaking initiatives and reevaluate old regulations. ${ }^{306}$ It could also reduce the delays between a petition to the agency

301. See Pierce, supra note 11, at 316 (arguing for "greater judicial conservatisin on the part of courts in reviewing agency policy decisions").

302. 5 U.S.C. § 553(e) (1988).

303. Id.

304. See Wild Horse Protection Ass'n v. Lyng, 812 F.2d 1, 7 (D.C. Cir. 1987); WWHT, Inc. v. FCC, 656 F.2d 807, 809 (D.C. Cir. 1981); Geller v. FCC, 610 F.2d 973, 977 (D.C. Cir. 1979) (limiting review of FCC orders to those imitiated within 60 days).

305. See 33 U.S.C. § 1365(a)(2) (1988) (Clean Water Act); 42 U.S.C. § 6972(a)(2) (1988) (Clean Air Act); id. § 7604(a)(2) (Clean Air Act).

306. See Sunstein, supra note 75 , at 524 (describing rulemaking initiatives brought about through bureaucracy-forcing lawsuits). 
and the agency's response to that petition. By supplying regulatees and beneficiary groups with a vehicle for stimulating administrative ruleinaking, these devices enhance agency accountability. No longer can an agency avoid inaking difficult technical judgments or put off resolving serious internal policy disputes through the simple expedient of placing the intractable subject matter indefinitely on the back burner. The threat of being held in contempt of court is usually an effective tool for making the necessary bureaucratic players sit up and take notice. ${ }^{307}$ Indeed, bureaucracy-forcing lawsuits can have tlie salutary effect of inducing agencies to set their own priorities so as to avoid liaving the courts estabhish their agendas for them. ${ }^{308}$

Finally, statutory and judicial deadlines can prevent OMB from tying up rulemaking imitiatives in never-ending dialogues with the agency. ${ }^{309}$ One court has held that the need to complete OMB review is not an excuse for missing a court-ordered deadline. ${ }^{310}$ Although strict judicial enforceinent of deadlines may encourage agencies to "game" OMB by submitting rules so close to the deadlines that effective review is mipossible, OMB should be able to cure this problem by inonitoring the agency's regulatory agenda carefully. ${ }^{311}$

Bureaucracy-forcing lawsuits, however, have unany serious drawbacks. A proliferation of statutory and judicial deadlines could create an immense strain on limited agency ruleinaking resources. ${ }^{312}$ Facilitating

307. For example, one OSHA official interviewed by Professor Shapiro and the author for a project sponsored by the Administrative Conference of the United States was pleased that the rulemaking initiative for which she was responsible became subject to a court-ordered deadline, becanse it gave added force to her denuands to officials in other offices over which she had no direct control that they coniplete their tasks on time. Telephone Interview with Dr. Inıgene E. Sevin, Health Standards Directorate, Ocenpational Safety and Health Administration (Nov. 3, 5, 1986).

308. See Sidney A. Shapiro \& Thomas O. McGarity, Reorienting OSHA: Regulatory Alternatives and Legislative Reform, 6 YALE J. ON REG. 1 (1989) (arguing that OSHA should establish its own priorities so as to avoid judicially-inıposed rulenuaking requirenıents).

309. But see Alden F. Abbott, The Case Against Federal Statutory and Judicial Deadlines: $A$ Cost-Benefit Appraisal, 39 ADMIN. L. REv. 171, 184 n.57 (1987) (arguing that OMB does not canse significant delay in agency rulentaking, relying upon OMB's statistics on average review times).

310. Environmental Defense Fund v. Thonas, 627 F. Supp. 566, 571 (D.D.C. 1986).

311. Although deadlines can force OMB to complete its reviews, they do not necessarily reduce the degrec of substantive control that $O M B$ has over the outcoine of the ruleniaking process. For example, when OSHA subinitted a final rule for ethylene oxide to OMB very near to a judiciallyiniposed deadline, OMB on the night before the deadline successfully deinanded that the agency delete a critical provision and chip out of the proposed preamble the agency's rationale for that provision. See Rowland Brief, supra note 242; Burnham, supra note 242, at A19; Ethylene Oxide, 14 O.S.H. Rep. (BNA) 334 (Sept. 20, 1984).

312. See R. Shep Melnick, Regulation and the Courts: The Case of the Clean AIR ACT 189-90 (1983) (arguing that congressional deadlines can stinulate agencies ouly if they are believable); Abbott, supra note 309, at 182 (alluding to the "tension between an ambitious authorizing statute and a inore realistic appropriation"); Graham, supra note 115, at 123. 
judicial review of agency inaction would almost certainly interfere with any existing priority-setting activities. ${ }^{313}$ Agencies that go to soine effort to establish rational priorities will not welcone outsider attempts to change those priorities to fit their perceptions of the best public policy. Yet it is difficult to syinpathize with the fears of an agency that has made no observable atteinpt to set priorities and that promulgates rules at the ponderous pace of one or two per year.

If the agency's rulemaking pace is slow because of its lack of resources, deadlines inay not be the solution. Indeed, limited agency resources nay be expended in litigation over deadlines rather than in writing regulations. ${ }^{314}$ On the other hand, as the agency begins to miss statutory or judicially imposed deadlines, public and congressional attention should begin to focus upon the agency's resource sliortage. Often the problein is not so inuch congressional parsimony as it is a lack of presidential commitment to the agency's prograin. A record of missed deadlines can demonstrate to Congress and the public that presidential assurances that the agency can do its job within the resources available in the administration's budget are not credible.

When agencies work feverishly under thic threat of statutory or judicially imposed deadlines, the quality of the output may suffer. ${ }^{315}$ Statutory or judicially imposed deadlimes may force agencies to give short shrift to public comments, thereby conveying the impression that the agency is not responsive to the affected public. ${ }^{316}$ Hasty agency action may result in flawed analyses and poor explanations, the hallmarks of arbitrary and capricious action. For exannle, Judge MacKinnon complained during the D.C. Circuit's review of an early EPA regulation pliasing lead additives out of gasoline, that the agency's somewhat superficial analysis was an inevitable consequence of the fact that another panel of that court had ordered it to promulgate a rule within thirty

313. See Administrative Conference of the United States, Reconmendation No. 78-3, Time Limits on Agency Actions, 1 C.F.R. § 305.78-3(d) (1991) [hereinafter Recommendation 78-3] ("Statutory time limits tend to undermine an agency's ability to establish priorities and to control the course of its proceedings."); Abbott, supra note 309, at 192 ("To the extent that deadlines induce an agency to forego dealing with ... previously unanticipated, and potentially more important problems, regulatory resources are misallocated and social welfare is diminished."); Graham, supra note 115, at 124 (noting that judicial enforcement of statutory deadlines for some hazardous air pollutants "accelerated regulatory analysis of these pollutants by indirectly bringing about a shift of EPA resources from other projects").

314. See Abbott, supra note 309, at 172.

315. See id.; see also Eisner, supra note 53, at $22-23$ (discussing the inconclusive nature of the courts' treatment of the appropriate standard of review where agencies fail to meet mandatory deadlines).

316. See Eisner, supra note 53, at 33 (discussing how arbitrarily conceived deadlines may force public comment periods to be reduced to such a length that they become meaningless). 
days. ${ }^{317}$ If the effect of one court's ordering an agency to march up the hill is another court's ordering it to march back down again, the whole bureaucracy-forcing exercise assumes an air of frustration and futility.

When an agency has put into place a priority-setting process that invites public participation, and is acting in good faith to adhere to its own rulemaking priorities within its own resource constraints, it is not desirable to give outsiders an additional degree of control over the agency's agenda. ${ }^{318}$ Since most agencies have not been successful im establishing and adhering to their own agendas, however, agency-stimulating techiriques should generally be available when agencies refuse to take up important rulemaking imitiatives that would clearly advance their statutory objectives. ${ }^{319}$ Congress should pay particular attention to the statutes of agencies for which indecision and delay have proven particularly intractable, 320 and should impose judicially enforceable statutory deadlines for such programs. ${ }^{321}$ The courts should not be reluctant to

317. Ethyl Corp. v. EPA, 541 F.2d 1, 69-70 (D.C. Cir.) (MacKinnon, J., dissenting), cert. denied, 426 U.S. 941 (1976).

318. See Recommendation No. 78-3, supra note 313, at 91-92 ("Before determining to impose statutory time limits for the conduct of agency proceedings, Congress should give due consideration to the alternative of requiring the agency itself to establish timetables or guidelines for the prompt disposition of various types of proceedings conducted by it."); Eisner, supra note 53, at 48 ("Consideration of public comment on the choice of any agency decision to allocate its himited resources to one rulemaking over another-and thus delay the second-strengthens the reasonableness of that decision.").

319. Some commentators have read Heckler v. Chaney, 470 U.S. 821 (1985), broadly to include agency decisions not to initiate the process of determining whether to issue a rule on a particular topic within the classes of actions that are unreviewable or only marginally reviewable under the Administrative Procedure Act. See Antonin Scalia, Responsibilities of Regulatory Agencies Under Environmental Laws, 24 Hous. L. REV. 97, 105 (1987) ("Perhaps the greatest degree of agency discretion is involved in deciding whether to assess a penalty against a particular polluter, or, even before that stage, whether to investigate a particular source to assess compliance; or, even before that stage, whether immediately to issue a particular regulation; or, even before that stage, whether to investigate a particular pollutant or activity as a possible subject for regulation.") (footnote omitted). Heckler itself is limited to the particnlar context of an enforcenent action in which the agency has made a decision not to pursue an individual, a context im which courts are espeeially ill-equipped to second-guess administrative judginents and in which individual rights play an important role. The stand-offish judicial posture denranded in that context is not necessarily appropriate in contexts in which the agency has failed an obligation to protect the statutory beneficiaries by issuing a rule.

320. In the author's opinion, OSHA, CPSC, and FTC clearly fit this criteria. Congress has apparently determined that EPA also neets this criteria, because it has increasingly resorted to statutory deadlines to ensure that the agency inplements its statutory coinunands. For example, the 1984 aniendments to the Resource Conservation and Recovery Act subject EPA to approximately 60 separate deadlines, see Abbott, supra note 309, at 173, and the 1990 amendments to the Clean Air Act contain deadlines requiring EPA to issue 55 rules in the first two years following the effective date of the Act. Agency Working with 'Evangelic Fervor' to Meet Air Act Deadlines, Analyst Says, 21 Env't Rep. (BNA) 2141 (April 5, 1991) (statement of Assistant Administrator William G. Rosenburg).

321. A recently introduced OSHA Reform Bill would subjeet OSHA to more deadlines for completing mlemaking initiatives. See Comprehensive Oceupational Health and Safety Reform Act, S. 
enforce statutory deadlines, whether or not the agencies can make a good case for delay. When a statute specifies a deadline, the courts should respect the congressional choice. ${ }^{322}$

When Congress has not specified a statutory deadline, the courts should be willing to police agency compliance with the APA's requirement that agency action not be unreasonably delayed. ${ }^{323}$ However, if the agency can point to a pre-existing priority-setting scheme under which other rulemaking initiatives, to which the agency is in good faith devoting resources, have a higher priority than the rulemaking at issue, then the courts should respect the agency's choices. Whether the court should intervene in cases in which the agency does not have a pre-existing priority-setting scheme in place should depend upon a balancing of factors. These factors mclude the availability of resources to the agency, indications of bad faith on the part of the agency, the petitioners' interests in expedition, and any indicators of congressional intent that the agency act expeditiously. ${ }^{324}$

Finally, Congress could anend the APA to require agencies to specify a deadline for final rulemaking at the tinie that a notice of proposed

1622, 102nd Cong., 1st Sess. (1991); H.R. 3160, 102nd Cong., 1st Sess. $§ 408$ (1991). But see Recommendation No. 78-3, supra note 313 , at 92 (stating that "Congress ordinarily should not impose statutory time limits on rulenaking proceedings").

Another little-used technique for congressional stimulation of agency ruleınaking is a requirement that the agency promulgate a rule on a specified subject inatter prior to expending a predetermined percentage of its budget. See, eg., Department of Transportation and Related Agencies Appropriations Act, Pub. L. No. 100-202, 101 Stat. 1329-358, 1329-358 to 359 (1987).

322. If the courts refuse to enforce congressionally-established deadlines, Congress could make greater use of a technique called the "liammer" to provide the affected industry an incentive to press the agency to proinulgate rules expeditiously. A "hammer" is a congressionally-specified regulation of greater stringency than any likely agency rule on the subject matter that automatically goes into effect by a statutory deadline if the agency has not promulgated a final rule on its own by that time. See 42 U.S.C. § 6924(d)-(g) (1988) (providing numerons hammers, including a complete ban on hazardous wastes from land disposal if the agency has not promulgated regulations on methods of land disposal for certain hazardous wastes within 66 months of the enactınent of the requirenents); 49 U.S.C. $\$ 2707$ (f)(4) app. (1988) (setting forth procedures to take effect if the agency fails to issue a rule).

323. Some judges and commentators suggest that courts generally should not be about the business of ensuring, at the behest of statutory beneficiaries, that agencies live up to congressional expectations, insisting that this task is too "political" in nature to be lodged in the judiciary. See Scalia, supra note 319, at 106 ("An agency that exercises its discretion in the direction of more linited application of the environmental laws is not necessarily false to its responsibilities; and an agency that exercises it in the direction of more expansive application is not necessarily true to thein."). If this becomes the prevalent judicial attitude, then the only vehicle Congress has for sending agencies and reviewing courts the message that implementation of congressionally-established programs is a matter of great public importance will be statutory deadlines, however awkward their judicial enforcement may be.

324. See Levin, supra note $\mathbf{1 2 5}$, at $\mathbf{2 8 8 - 8 9}$ (discussing additional factors which inerit consideration in determining whether an agency's failure to complete a pending action is unreasonable and unlawful). 
rulemaking is published in the Federal Register. ${ }^{325}$ This voluntary deadline could be policed in subsequent judicial actions. Although agencies could easily avoid any real threat of a bureaucracy-forcing lawsuit by specifying deadlines in the far-off future, pohtical pressures may prevent agencies from beimg too unrealistic in setting their own deadlines. This solution does not reach the problein of agency delay in proposing the rule in the first place, but it should help speed the process along once the agencies have so sufficiently committed themselves to rulemaking initiatives as to publish notices of proposed rulemaking.

\section{Writing Different Kinds of Rules}

1. "Lite" Rules. Rather than regulate as stringently as the statute would allow (or require), an agency could write rules that accoinphish some improvement without imcurring the adamant opposition of tlie regulated industries. OSHA atteinpted to iniplement this approach wlien it recently revised the permissible exposure levels for approximately 400 toxic chemicals for which private and quasi-governmental standard-setting agencies have suggested revised limits. OSHA liad the option of imitiating full-fledged rulemaking initiatives aimed at identifying the lowest feasible exposure level necessary to eliminate significant risks in all workplaces for each imdividual chennical. At OSHA's current pace, this would have taken decades. Ratlier than write 400 separate stringent rules providing all the protections within the agency's power, the agency elected to write a simgle generic rule that required that exposures be reduced to tlie less stringent privately established recommendations. OSHA hoped that reduced industry opposition to this "hite" rule would allow the agency to survive judicial review witl a less complete record for eacli substance. The gambit did not elinmate all industry opposition, however, and the generic rule was ultiniately overturned by the Eleventh Circuit in an opinion that casts serious doubt on OSHA's abihty to write generic "lite" rules. ${ }^{326}$

This novel approach gives the agency the flexibility to undertake a little bit of regulation relatively rapidly at sharply reduced resource expenditures. It does not, however, greatly advance tlie agency's statutory

325. See S. 1080, 98th Cong., 1st Sess. $\$ 4($ a) (1983) (proposing that the APA be amended by adding $\S 633$ (a)(1) - Establishment of Deadlines); Abbott, supra note 309, at 172. The Administrative Conference has suggested that agencies specify voluntary deadlines in notices of proposed rulemaking. See Recommendation No. 78-3, supra note 313 (preferring that reasonable timetables or deadlines be created by the agency itself, as opposed to statutory creation); Adininistrative Conference of the United States, Recommendation No. 87-10, Regulation by the Occupational Safety and Health Administration, 1 C.F.R. $\S 305.87-10$ (1991) (instructing OSHA to develop procedures to ensure that ruleinaking establishınents will be carried out in a timely fashion).

326. AFL-CIO v. OSHA, 965 F.2d 962 (11th Cir. 1992). 
goals. If the agency's goal is merely to promulgate rules that the regulated industry can "live with," it is not likely to achieve results that significantly depart from the status quo. For both practical and symbolic reasons, the beneficiaries of the regulatory program are, therefore, not likely to be satisfied with the half-a-loaf aspects of this approach. Nevertheless, there may be a few limited areas in which "lite" rules will pave the way toward more thoroughgoing regulation and therefore will be acceptable to mdustry and beneficiaries alike.

2. "Tentative" Rules. If the ossification problem steins froin the lack of flexibility or incentive to reexamine existing rules, an agency could experiment with promulgatimg rules that have fixed termination dates. Under this approach the original rule would provide that unless the agency completed a new rulemaking with a fresh round of noticeand-comment prior to a specified deadline, the rule would be automatically repealed. The agency would thus commit itself to revisit such rules periodically.

Secure in the knowledge that the agency will be reexamining the rule in the near future, the regulated industry and beneficiary groups may not be as inclined to challenge it. Writing tentative rules would also ensure that the agency would have a predetermined opporturity to reexainme the scientific and technical premises underlying the previous rulennaking. This would be especially useful in areas where the underlying science is rapidly evolving. Tentative rulemaking may also make the agency less hesitant to begin new rulemaking mitiatives. The argument that the facts are not yet sufficiently well understood is less forceful in the context of a tentative rulemaking in which the agency can change the regulation at the next rulemaking round if the factual basis for the first regulation is undermined during the interim period.

Tentative rulemaking could be quite burdensoine if the agency were obliged to revisit every rule on a periodic basis. When the agency spends all of its resources scrambling to keep existing rules froin expiring, it inay not be able to get around to many new ruleinaking initiatives. Moreover, both regulatees and beneficiaries value stability to some extent. The prospect that the regulation will be amended in a siguificant way in the next rulemaking cycle may hamper long-range planning. Despite these disadvantages, the agency should atteinpt tentative rulemaking on an experimental basis in programs where new information is constantly becoming available. 


\section{J. Sunset for Rules}

A niore draconian solution would be to amend agency statutes to take the discretion to reexamine rules away from the agencies by creating a Conimission (perhaps an interagency commission or perhaps a commission with membership from Congress and the executive branch) to examine all existing major rules and to designate some for "sunset." "Sunset" designation would require the agency to initiate a new ruleniaking proceeding with respect to the rule within a prescribed period of tinie. The agency could propose the same rule agam, but it would have to nieet existing analytical requirements, allow notice-and-comment, and perhaps survive judicial review. This would be similar to the approach that the Bush Task Force adopted at the outset of the Reagan Adnimistration. ${ }^{327}$

The advantages of this approach are similar to those of tentative ruleniaking. An additional advantage is that it does not affect all rules; it ouly apphes to rules identified by the commission as particularly well suited for reexamination. The process could, however, become highly politicized. The commission might not identify rules for which the factual basis had been undermined as nuch as it inight identify rules that were especially expensive to comply with or otherwise pohtically unpopular. But pohticization could be avoided to some extent by ensuring that the members of the Commission were "neutral." If extreine care is taken to avoid partisan wrangling, the idea may be worth trying on an experimental basis.

\section{K. Sunrise for Rules}

Congress could enipower some entity (perhaps OMB or perhaps a separate commission) to designate certain rules (either new rules or reexaminations of existing rules) for a "fast track" im which most or all of the procedural, analytical, and/or substantive review requirenients could be waived. The model for this approach could be the "Energy Mobilization Board" suggested during the Carter Administration. ${ }^{328}$ Putting a few very important rulemaking initiatives on a fast track could greatly enhance the flexibility of the ruleniaking process for those rules.

It would, however, probably be difficult to articulate the criteria for singling out rules for favored treatment. In addition, the courts may

327. In 1981, the President's Task Force on Regulatory Relief, headed by Vice-President George Bush, solicited suggestions from industry for a "hit list" of regulations that the Task Force would order the executive agencies to reconsider under the criteria of Executive Order 12,291. Letter from George Bush to Small Business Groups (March 25, 1981).

328. Charles R. Ching, Note, Energy Facility Siting: Recent Models of Reform, 56 WASH. L. REV. 467, 472 (1981). 
have a difficult time performing their (perhaps modified) judicial review if the abbreviated record that results does not set out the agency's reasonmg process or the factual predicates for the rule. The process could be easily politicized. It would probably be resisted by beneficiary groups on the ground that it would allow some highly unattractive rules (or repeals of rules) to go imto effect without adequate consideration. Althougli the idea may prove alluring to those who are ready to adopt a "brute force" strategy for the Gordian knot of rulemaking procedures, its potential for mischief may well outweigh its usefuhress.

\section{CONCLUSIONS AND RECOMMENDATIONS}

The informal rulemaking revolution of the 1960s and early 1970s has reached its thermidor. The reactions of the three constitutional branches to this innovative approach to administrative governance by the unofficial "fourth brancli" has so thoroughly disabled it that it is in danger of becoming a historical monument, a symbol of the fate of a "good government" idea in a world dominated by powerful interest groups. To some degree, externally miposed constramts on informal rulemaking were an mevitable product of the tension between innovation and accountability that must always exist in a democracy that aspires to the rule of law. But to a larger degree, the ossification of the ruleinaking process was an avoidable consequence of unrealistic expectations about the ability of resonrce-starved regulatory agencies to identify, analyze, and resolve exceedingly complex regulatory issues on the cutting edge of science, technology, economics, and psychology.

Altlough informal rulemaking should never be entirely free of constraints imposed by the President, Congress, and the courts, a successful future for this decisionnaking device requires that all three branches "back off" and let it function witl greater freedom and flexibility. This Article has suggested some "patch and repair" solutions aimed at enliancing the effectiveness of informal rulemaking process within the constraints of the existing institutional milieu. The most effective cure for what ails informal ruleinaking, lowever, would be a cliange in attitude among the current institutions with the power to affect that process about what can realistically be expected of government bureaucracies. If it is true that society is attempting to do too much through government regulation, the solution is to deregulate, not to hamstring the agencies that are trymg to implement existing laws. To the extent that society needs the services that the agencies are attempting to provide, the agencies should be free to provide those services through an efficient and effective informal rulemaking process unburdened by undue fears of judicial or political reversal. 